\title{
PERFIL DE AMINOÁCIDOS E ESTUDO DA CINÉTICA DE DEGRADAÇÃO RUMINAL DE ALIMENTOS EM BOVINOS NELORE RECEBENDO DIFERENTES PROPORÇÕES DE CONCENTRADO
}

\author{
MARCELO DE QUEIROZ MANELLA \\ Médico Veterinário
}

Orientador : Prof. Dr. CELSO BOIN

Tese apresentada à Escola Superior de Agricultura "Luiz de Queiroz", Universidade de São Paulo, para obtenção do título de Doutor em Agronomia, Área de Concentração: Ciência Animal e Pastagens.

PIRACICABA

Estado de São Paulo - Brasil

Janeiro - 2004 


\title{
Dados Internacionais de Catalogação na Publicação (CIP) DIVISÃO DE BIBLIOTECA E DOCUMENTAÇÃO - ESALQ/USP
}

\author{
Manella, Marcelo de Queiroz \\ Perfil de aminoácidos e estudo a cinética de degradação ruminal de alimentos em \\ bovinos nelore recebendo diferentes proporções de concentrado / Marcelo de \\ Queiroz Manella. - - Piracicaba, 2003. \\ 104 p. : il.
}

Tese (doutorado) - - Escola Superior de Agricultura Luiz de Queiroz, 2004. Bibliografia.

1. Aminoácidos 2. Bovinos de corte 3. Contaminação microbiana 4. Digestibilidade 5. Isótopos estáveis 6. Nutrição animal 7. Proteínas 8. Rúmen 9. Suplementos concentrados para animais I. Título

CDD 636.2085

\section{"Permitida a cópia total ou parcial deste documento, desde que citada a fonte - $\mathrm{O}$ autor"}

Data de depósito junto CPG/ESALC

$06 / 01 / 04$ 
À minha filha, Marina,

Cujo os olhos azuis e o eterno sorriso são minha maior inspiração

E aos meus pais Maria Aparecida e José Nazareno, e aos Tios Paulo e Amélia por sempre me incentivaram e apoiaram nas decisões da minha carreira. 


\section{AGRADECIMENTOS}

À Escola Superior de Agricultura Luiz de Queiroz (USP) e em especial ao Departamento de Produção Animal, pela oportunidade de realização deste curso.

Ao Prof. Dr. Celso Boin pela orientação segura, pelos ensinamentos valiosos, pela confiança e exemplo de profissional.

Á Fundaçăo de Amparo à Pesquisa do Estado de São Paulo (FAPESP), pela concessão da bolsa de estudos durante o transcorrer do curso e pelo financiamento do projeto.

Ao Instituto de Zootecnia de Nova Odessa por ter cedido a estrutura e permitir a realização de meus trabalhos, bem como aos seus pesquisadores pelos laços de amizade lá criados.

Aos amigos Dr. Antônio João Lourenço, Dr. Guilherme Fernando Alleoni e Dr. João José A. A. Demarchi que muito colaboraram no meu aprendizado e pela oportunidade de participar de outros trabalhos ao longo do período de convivência.

Aos colegas Dr. Luis Orlindo Tedeshi e Ivani Posar Otsuk que pacientemente me auxiliaram na análise estatística dos dados.

Ao amigo José Oliveira de Andrade, o Zé Mineiro, pelo adestramento dos animais, e auxilio na condução do experimento, sendo ele o principal responsável pelo bom andamento de todo o experimento.

Aos técnicos do laboratório e funcionários do Instituto de Zootecnia: Maria Aparecida Menale, Sergio Roberto Miante, Neusa Aparecida Chaves, Carmen de Lourdes Terra, Zenairde Ribeiro da Silva Paloma, Nivaldo Martins, José Aparecido de Oliveira, Olinda Aparecida de Oliveira, Floripes Maria do Amaral e Antônia Casagrande, que de alguma forma contribuíram para a execução dos trabalhos. ${ }^{15} \mathrm{~N}$.

Ao Prof. Dr; Paulo C. O. Trivilin e ao CENA pelas determinações de

Aos amigos André Alves de Souza e Vicente França Turino pelo auxílio na cirurgia de colocação das cânulas nos animais.

Aos colegas do Laboratório de Nutrição e Crescimento Animal (Sergio, Amanda, Marco, Dimas, Marina, Rodrigo, Liana, Adriana, Liris, Andrea, Juliano, Alexandre, Rodrigo, Laudi, Tuka, Ana Paulae ao Prof. Dr. Dante Pazzanese Duarte Lanna, cuja convivência permitiu desfrutar de vários momentos agradáveis.

Às pessoas que, direta ou indiretamente, contribuíram para a realização deste trabalho.

\section{OBRIGADO}




\section{SUMÁRIO}

RESUMOS

Pagina

SUMMARY

viii

INTRODUÇÃO GERAL

$x$

2

REVISÃO DE LITERATURA

2.1 Estudo do valor nutritivo dos alimentos .......................................... 3

2.2 Contaminação Microbiana do resíduo da incubação ruminal............... 8

2.3 Aminoácidos para ruminantes........................................................ 11

3 EFEITO DA DIFERENTES PROPORÇÕES DE CONCENTRADO NA CONTAMINAÇÃO MICROBIANA PELA TÉCNICA DO ${ }^{15} \mathrm{~N}$ NOS RESIDUOS DOS ALIMENTOS E NAS CARACTERISTIICAS DE FERMENTAÇÃO RUMINAL

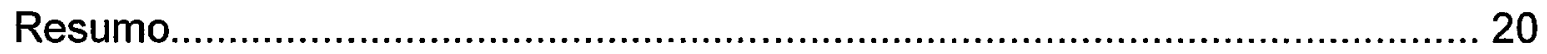

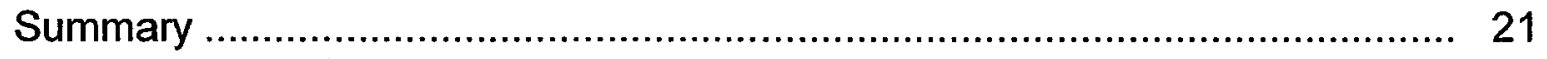

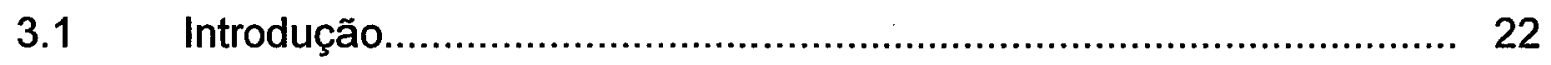

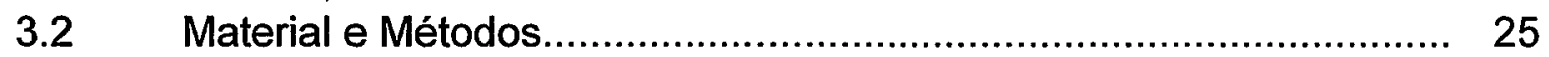

3.2.1 Animais e dieta experimental................................................... 25

3.2.2 Infusão de ${ }^{15} \mathrm{~N}$ no rúmen....................................................... 27

3.2.3 Separação do pool de bactérias do conteúdo ruminal...................... 27

3.2.4 Avaliação da contaminação do resíduo de incubação ruminal.......... 27

3.2.5 Determinação do ${ }^{15} \mathrm{~N}$ e $\mathrm{N}$ da contaminação microbiana do resíduo 28

3.2.6 Coleta do líquido ruminal....................................................... 30

3.2.7 Determinação do nitrogênio amoniacal no rúmen........................... 30

3.2.8 Determinação de ácidos graxos voláteis........................................ 31

3.2.9 Análise bromatoloógica....................................................... 32

3.2.10 Análise estatística.................................................................. 32 
3.3 Resultados e discussão........................................................ 32

Conclusões........................................................................ 44

4 EFEITO DA DIFERENTES PROPORÇÕES DE CONCENTRADO NA NA CINÉTICA DE DEGRADAÇÃO DOS ALIMENTOS CORRIGIDOS OU NÄO PARA CONTAMINAÇÃO MICROBIANA..... 46

Resumo.

Summary.

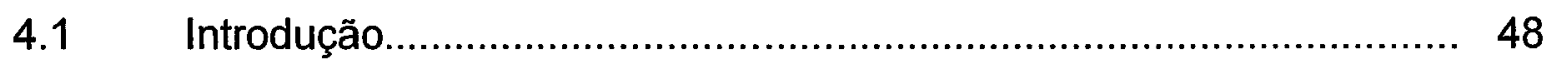

$4.2 \quad$ Material e Métodos............................................................... 50

4.2.1 Animais e dieta experimental................................................... 50

4.2.2 Degradabilidade ruminal........................................................ 52

4.2.3 Infusão de ${ }^{15} \mathrm{~N}$ no rúmen........................................................... 54

4.2.4 Determinação do ${ }^{15} \mathrm{~N}$ e $\mathrm{N}$ da contaminação microbiana do resíduo... 54

4.2.5 Digestibilidade intestinal in vitro da proteína bruta.......................... 55

4.2.6 Análise bromatológica............................................................ 56

4.2.7 Análise estatística............................................................... 56

$4.2 \quad$ Resultados e discussões............................................................. 56

$4.4 \quad$ Conclusões.............................................................................. 69

5 EFEITO DA DIFERENTES PROPORÇÕES DE CONCENTRADO NA DEGRADAÇĀO E PERFIL DOS AMINOÁCIDOS ...................... 70

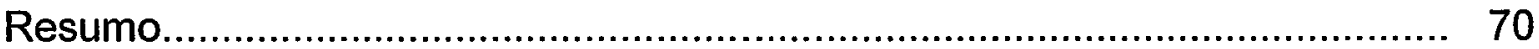

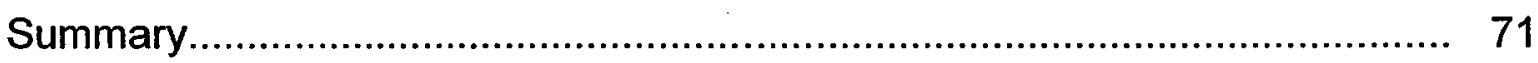

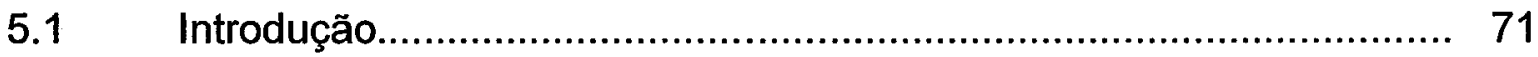

$5.2 \quad$ Material e Métodos..................................................................... 73

5.2.1 Animais e dieta experimental................................................ 73

5.2.2 Degradabilidade dos aminoácidos............................................. 74

5.2.3 Deterninação dos aminoácidos dos alimentos................................. 75

5.2.4 Determinação da contaminação microbiana do resíduo................... 76

5.2.5 Análise estatística.................................................................... 77

$5.3 \quad$ Resultados e discussão............................................................ 78

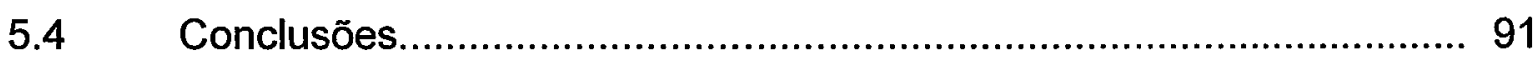

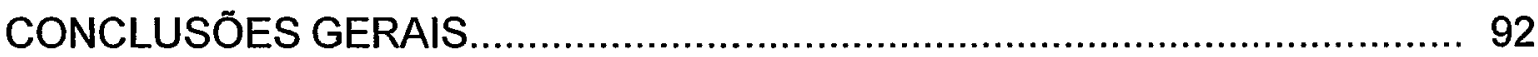


REFERÊNCIAS BIBLIOGRÁFICAS 


\title{
PERFIL DE AMINOÁCIDOS E ESTUDO DA CINÉTICA DE DEGRADAÇÃO RUMINAL DE ALIMENTOS EM BOVINOS NELORE RECEBENDO DIFERENTES PROPORÇÕES DE CONCENTRADO
}

\author{
Aluno: MARCELO DE QUEIROZ MANELLA \\ Orientador: Prof. Dr. CELSO BOIN
}

\section{RESUMO}

Foram utilizados seis bovinos Nelore canulados no rúmen dispostos em quadrado latino $(3 \times 3)$ com repetição, com o objetivo de avaliar os efeitos de diferentes proporções de concentrado $(20,40$ e $60 \%)$ na dieta. Os alimentos testados foram: casca de soja, milho, sorgo, farelo de algodão, farelo de soja e farelo proteinoso de milho. Foi observada interação entre alimento e tempo de incubação, para a contaminação microbiana. A contaminação do resíduo de incubação ruminal aumentou, de forma geral, com o tempo de exposição ruminal, sendo que as principais variações ocorreram em relação à \%Nbact. $\mathrm{O}$ milho, farelo de algodão e sorgo apresentaram maiores \%Nbact nos tempos de 24 e $48 \mathrm{~h}$ e o farelo de soja apenas com $48 \mathrm{~h}$. O farelo proteinoso do milho e a casca de soja apresentaram maiores \%NBact nos tempos de 24,48 e $60 \mathrm{~h}$. O tratamento com $60 \%$ quando comparado com os tratamentos com 20 e $40 \%$ de concentrado apresentou menor valor médio de $\mathrm{pH}$, maior produção de ácidos graxos voláteis, menor proporção de ácido acético, aumento da proporção molar de ácido propiónico, menores relações entre acético:propiónico . maior 
proporção de ácido butírico e menor concentração $\mathrm{N}-\mathrm{NH}_{3}$. A casca de soja apresentou valores de degradabilidade efetiva (DE) da PB corrigida para contaminação microbiana maiores para todas as taxas de passagem que as estimativas feitas sem correção. O milho teve maior DE para o tratamento $60 \%$ para a MS $(2,0,5,0$ e $8,0 \% / h)$, e para PB $(k p=8,0 \% / h)$. As DE's da PB do farelo proteinoso de milho com $k p$ de 2, 5 e $8 \% / h$ apresentaram efeito significativos para correção da contaminação microbiana do resíduo. $O$ farelo de soja apresentou efeito de tratamento para a DE da MS com $k p$ de 5,0 e $8,0 \% / h$ e da PB com $k p$ de $8,0 \% / h$, sendo menor os valores para o tratamento $60 \%$. A correção do residuo do farelo de algodão para contaminação microbiano apresentou efeito significativo $(P<0,10)$ na $D E$ da MS para todas as taxas de passagem e na DE da PB apenas para $k p$ de $2 \% / h$. Os maiores valores para digestibilidade intestinal da proteina não degradada no rúmen foram observados para casca de soja $(81,7 \%)$, milho $(87,1 \%)$ e sorgo $(82,4 \%)$, enquanto que os menores foram os do farelo proteinoso de milho $(57,6 \%)$ e do farelo de soja $(53,4 \%, \quad \mathrm{P}<0,10)$, e o farelo de algodão $(70,9 \%)$ valor intermediário. A digestibilidade total da proteína dos alimentos diferiram entre si, sendo que apenas o milho e o farelo proteinoso de milho apresentaram digestibilidade semelhantes.. Houve efeito apenas do tipo de alimentos para a degradação de aminoácidos, onde as menores degradações foram observadas para o sorgo e as maiores para o farelo proteinoso de milho. A degradabilidade de cada aminoácido no alimento foi bastante variável, destacando a Iso, Leu e Val, que foram os de menor degradação em relação à média dos aminoácidos totais para quase todos os alimento, com exceção da casca de soja. Os aminoácidos individuais apresentam diferentes degradações, sendo variável entre os alimentos. Estas diferenças promoveram alterações significativas no perfil de aminoácidos dos alimentos incubados em relação ao original, devendo ser considerada pelos sistemas de avaliação de dietas. 


\title{
AMINO ACIDS PROFILE AND RUMEN DEGRADATION KINETICS OF FEEDSTUFFS INCUBATED IN NELORE STEERS FED WITH DIFFERENT RATIOS OF CONCENTRATES
}

\author{
Author: MARCELO DE QUEIROZ MANELLA
} Adviser: Prof. Dr. CELSO BOIN

\section{SUMMARY}

Six rumen cannulated Nelore steer were used in replicated latin square design $(3 \times 3)$, with the objective of analyze the effects of different ratios of concentrate $(20,40,60 \%)$. The feed evaluated were soybean hulls, corn, sorghum grain, soybean meal, cottonseed meal and corn gluten feed. There was an interaction among feed and incubation period for microbial contamination. The residue contamination increased with rumen exposure for all feeds, and the main variations detected were with $\%$ residual bacterial nitrogen (\%Nbact). The corn, cottonseed meal and the sorghum showed higher \%Nbact after 24 and $48 \mathrm{~h}$ of rumen exposure, and the soy bean meal only after $48 \mathrm{~h}$. The corn gluten feed and soy bean hulls had the largest \%Nbact contamination after 24,48 and $60 \mathrm{~h}$ of rumen exposure. The treatment with $60 \%$ of concentrate, when compared with 20 and $40 \%$ had lower mean $\mathrm{pH}$, higher volatile fatty acids production $(P<0,05)$, lower acetic acid proportion, because the increased of the proportion of propionic acid $(P<0,05)$, which caused a lower ratios of acetate:propionate, higher molar proportion of butyric acid, and lower rumen ammonia nitrogen $\left(\mathrm{N}-\mathrm{NH}_{3}\right.$ ). The soybean hulls had higher rumen effective degradability when corrected for microbial contamination for all estimated 
passages rates. The corn had higher rumen dry matter effective degradability (ED) with animals on $60 \%$ concentrated treatment, and the CP were higher only with passage rates of $5 \% / \mathrm{h}$. The $\mathrm{CP}$ effective degradability of the corn gluten feed showed a significant difference when corrected for microbial nitrogen contamination. The dry matter ED of soy bean meal of animal on $60 \%$ concentrate diet showed lower values with passage rates of 5 and $8 \% / \mathrm{h}$. The microbial contamination correction of the cottonseed meal residues had a significant effect of dry matter ED with all the passage rates, and for the CP were significant only with estimates of $2 \% / \mathrm{h}$. The in vitro intestinal digestibilities rumen undegradable protein (RUP) were higher to soy bean hulls $(81,7 \%)$, corn $(87,1 \%)$ and sorghum $(82,4 \%)$ than corn gluten meal $(57,6)$. The total digestibility estimated (rumen and intestine) were different and only corn and corn gluten meal had similar values. It was not detected variations on bacterial $\mathrm{CP}$ and amino acid composition among diets. There was a significant effect of feed for amino acids degradation, with the lower values for sorghum and the higher for corn gluten feed. The individual amino acid degradability were variable with different rates of degradability, and that resulted on profile changes after rumen exposure. 


\section{INTRODUÇÃO}

Bovinos têm como principal função à conversão de nutrientes de origem vegetal em alimentos (leite e carne) de alto valor nutritivo para alimentação humana. Na bovinocultura moderna a principal meta é aumentar a eficiência desta conversão, com menores custos de produção, sem causar impactos negativos ao meio ambiente. A eficiência desta conversão se deve a fatores como a genética do animal e a sua adaptação às condições ambientais em que se encontra. Entretanto, isto tem importância secundária em relação aos aspectos qualitativos dos ingredientes da dieta dos animais e da combinação destes para suprir as exigências nutricionais e explorar o potencial genético.

A digestão em ruminantes é um processo complexo, envolvendo atividade simbiótica dos microrganismos ruminais com o hospedeiro, sendo que estes são altamente susceptíveis a alterações do meio, e conseqüentemente afetando não só a extensão da degradação dos componentes dos alimentos como as quantidades e as proporções dos produtos resultantes da ação destes. Com base nisto, os sistemas de avaliação e formulação de dietas vem aprimorando seus modelos através do uso de informações da cinética da degradação das diferentes frações dos alimentos, e suas implicações nos padrões de fermentação e síntese de proteína microbiana e na disponibilidade $e$ qualidade dos ingredientes a serem absorvidos.

Nos últimos anos os nutricionistas de bovinos vêm desenvolvendo sistemas de formulação de dietas que visam adequar o balanço de proteína com a mesma precisão que a avicultura e suinocultura (Oldhan, 1993; Cozzi et al., 1995). Dietas ajustadas em função das estimativas das exigências dos 
aminoácidos, bem como o perfil destes, tendem a diminuir o teor proteína nas dietas (Boisen et al., 2000).

Desta maneira torna-se necessário o desenvolvimento de banco de dados para incorporação de novas informações, com diferentes condições ambientais e alimentares, aprimorando ainda mais os modelos já existentes.

O modelo Cornell Net Carbohydrate and Protein System (CNCPS, Fox et al., 2003) possui uma biblioteca tropical de alimentos com diversos dados gerados no Brasil (Tedeschi et al., 2002). Entretanto, ainda há a necessidade do aprimoramento e desenvolvimento de novas informações para o banco de dados tropical, principalmente em relação a cinética de degradação e perfil dos aminoácidos da proteína não degradável no rúmen (PNDR) dos alimentos, que ainda são escassos. 


\section{REVISÃO DE LITERATURA}

\subsection{Estudo do valor nutritivo dos alimentos}

As diferenças de valor nutritivo entre as fontes protéicas se devem principalmente não só em relação ao teor da proteína bruta (PB), mas também ao seu perfil de aminoácidos. Comparando-se animais monogástricos e ruminantes, o valor nutritivo difere de forma significativa em função das características da anatomia e fisiologia digestiva (Boisen et al., 2000). Em ruminantes o valor nutritivo da proteina, em algumas condições, tem importância reduzida em função do processo de fermentação microbiana.

A eficiência de conversão do alimento em produto animal (e.g. carne, leite) é determinada, principalmente, pelo valor nutritivo do alimento. Para monogástricos o valor pode ser dado apenas pela composição química do ingredientes, e pela quantidade absorvida nos intestinos. Para bovinos, além destes fatores deve-se considerar os efeitos da fermentação ruminal na degradação dos componentes dos alimentos e na sintese de compostos a serem utilizados pelo hospedeiro através da absorção ruminal e intestinal.

O valor nutritivo dos alimentos, em geral é avaliado pela sua composição química, principalmente em relação aos teores de proteína e de carboidratos, além é claro de vitaminas e minerais. Entretanto, associado-se as informações da composição química dos alimentos, o valor nutritivo também é dado pela disponibilidade dos nutrientes para fermentação microbiana, determinando a eficiência da mesma. A eficiência de digestão dos alimentos no rúmen, e a 
capacidade de transformação dos nutrientes em proteína de alta qualidade ocorrem em função da disponibilidade de energia e nitrogênio no rúmen para ótima atividade microbiana (Russell et al., 1992).

A associação entre a composição química e o potencial de degradação dos alimentos vai determinar o maior ou menor crescimento microbiano e produção de ácidos graxos voláteis no rúmen, que são as principais fontes de proteína e energia para bovinos, respectivamente (Church, 1990)

Os modelos para estimativas de exigência de proteína são os que mais vem recebendo alterações nos últimos anos. Na edição do National Research Council (NRC, 1984) expressava-se as exigências na forma de PB. No ano seguinte o sub-comite de "Nitrogen Usage in Ruminants" (National Research Council, 1985) propôs o uso das exigências de proteína em termos de proteína metabolizável. Este sistema considera a eficiência da síntese de proteína microbiana em função da relação entre a proteína degradável no rúmen (PDR) e os nutrientes digestiveis totais (NDT), e a proteina não degradada no rúmen (PNDR) da dieta, e a digestão de ambas no duodeno (NRC, 1985). Este é o sistema atualmente adotado pelo NRC (2000), NRC (2001) e o nível 1 do CNCPS. O Agriculture and Food Research Center (AFRC, 1995) adota conceitos semelhantes, porém a eficiência microbiana é dada em função da energia metabolizável fermentada no rúmen.

Já o nível 2 do sistema de CNCPS (Fox et al., 2000) integra as taxas de degradação das diferentes frações de carboidratos e proteína na síntese de proteína microbiana, fermentação ruminal e fluxo de nutrientes para absorção intestinal. A proteina é fracionada em: fração $A$ (fração solúvel-Nitrogênio não protéico, NNP); fração $B_{1}$ (fração solúvel rapidamente degradada no rúmen); fração $B_{2}$ (fração solúvel, com taxa de degradação intermediária no rúmen); fração $B_{3}$ (fração insolúvel lentamente degradada no rúmen); e a fração $C$ (fração que é indigestível durante a sua permanência no trato gastrintestinal). $O$ nível 2 aplica não só o conceito da proteína metabolizável (proteína microbiana 
+ PNDR) que chega ao duodeno, mas a qualidade desta proteína em função do perfil dos aminoácidos.

A deficiência de PDR, e conseqüentemente baixo teor de nitrogênio amoniacal $\left(\mathrm{N}-\mathrm{NH}_{3}\right)$, é o principal fator limitante para digestão da fibra devido à menor atividade bacteriana (Satter \& Slyter, 1974; Hoover \& Stokes, 1991). Segundo Church (1990) a maioria das bactérias são capazes de usar o $\mathrm{N}^{-\mathrm{NH}_{3}}$ como única fonte de nitrogênio, desta forma é necessário que a dieta promova concentrações adequadas no rúmen para a ótima atividade microbiana. Satter e Roffler (1979) propuseram que para a otimização da digestão da fibra a concentração ruminal deve estar entre 2,0 a $5,0 \mathrm{mg} / \mathrm{dl}$.

Bactérias celulolíticas usam basicamente apenas amônia como fonte de nitrogênio, e sua capacidade fermentativa é consideravelmente reduzida na ausência de $\mathrm{N}-\mathrm{NH}_{3}$, já que sua capacidade de usar $\mathrm{N}$ na forma de aminoácidos e peptídeos é bastante reduzida. Já as bactérias amilolíticas apresentam crescimento mais rápido, utilizando cerca de $64 \%$ de peptídeos e aminoácidos e 34 \% de amônia, como fontes de $\mathrm{N}$ para seu crescimento (Russell et al., 1992). Além disso, as bactérias que degradam amido, pectina ou açúcares são capazes de continuar a degradação do substrato mesmo quando $\mathrm{N}$ é limitante (Tedeschi et al., 2000a), ao passo que as bactérias que degradam fibra não. Esse fenômeno é conhecido como "energy spilling" ou gasto inútil de energia.

Para a otimização da produção de proteina microbiana é necessária a sincronização entre a disponibilidade de energia e compostos nitrogenados no ambiente ruminal (Russell et al., 1992; Firkins, 1996). Os microrganismos dependem da energia na forma de adenosina tri fosfato (ATP) oriunda da fermentação dos carboidratos para que a biosintese de proteína microbiana, caso contrário os peptídeos e aminoácidos passam a ser utilizados como fontes de energia, ocorrendo acúmulo de amônia no meio (Russell et al., 1992). Desta forma, a concentração de $\mathrm{N}-\mathrm{NH}_{3}$ no rúmen depende da degradabilidade da fonte protéica da disponibilidade de carboidratos (Satter e Roffler, 1979, Nocek 
e Russell, 1988) e do equilíbrio entre sua produção e utilização pelos microrganismos.

Os trabalhos realizados nos últimos anos têm demonstrado que a taxa e a quantidade de nutrientes degradados no rúmen podem ter grande impacto nos produtos finais da fermentação ruminal, e conseqüentemente no desempenho animal. Com isto, nos últimos anos os nutricionistas vem buscando balancear dietas de modo a sincronizar a degradação da proteína $e$ dos carboidratos. Se a taxa de degradação de proteina exceder a de carboidratos, grandes quantidades de nitrogênio podem ser perdidas na forma de amônia. Por outro lado, se a degradação de carboidratos for maior que a de proteína, a síntese microbiana vai ser menor (Russell et al., 1992; Van Kessel e Russell, 1996). A extensão com que os nutrientes são degradados é determinada estreitamente pela competição entre taxa de degradação e passagem, sendo que o conhecimento de ambas é necessário para estimar as quantidades de energia e de compostos nitrogenados disponiveis no rúmen (Russell et al., 1992).

Segundo Stokes et al. (1991), tanto níveis adequados de proteína degradável, e de carboidratos não estruturais, aumentam a eficiência microbiana, com melhoria na digestão dos alimentos, aumento na produção de ácidos graxos voláteis e conseqüentemente maior síntese de proteína microbiana.

Tedeschi et al. (2000a) concluíram que a inclusão, no modelo CNCPS, do balanço de nitrogênio no rúmen, melhora as estimativas para ganho de peso e consumo de matéria seca de bovinos de corte. Desta forma, torna-se ainda mais importante a busca por informações sobre as características dos alimentos, em diferentes condições alimentares, para estimar com maior precisão o balanço de $\mathrm{N}$ ruminal, e conseqüentemente prever consumo $\mathrm{e}$ desempenho dos animais.

As informações necessárias para estimar o balanço de nitrogênio para o ótimo crescimento bacteriano usado no modelo CNCPS (Fox et al 2000), são as 
taxas de degradação ruminal das frações de $\mathrm{N}$ e de carboidratos de cada ingrediente usado na dieta. A metodologia adotada pelos principais modelos (AFRC, 1995; INRA, 1989; NRC 1985, 2000, 2001) para determinação da cinética de degradação da proteína no rúmen é o método in situ com sacolas de nylon, além de métodos in vitro.

O método in situ, apesar das grandes variações entre laboratórios (Broderick e Cochran, 2000) é o mais utilizado, enquanto que o modelo matemático exponencial proposto por Ørskov e McDonald (1979) é comumente usado para descrever a cinética de degradação ruminal dos alimentos. As constantes matemáticas identificadas no modelo podem ser interpretadas como porção solúvel (a), potencialmente degradável (b), e a taxa de degradação da fração b (c). Para estimar a degradabilidade efetiva o modelo usa a taxa de passagem do alimento, podendo usar um valor determinado ou pré-fixado. Modelo similar foi adotado pelo NRC (2001) para descrever a cinética de degradação das frações protéicas.

A cinética de degradação de carboidratos e proteínas varia amplamente de acordo com o alimento, sua composição e arranjo estrutural, além do método de processamento (NRC, 2001). A extensão com que a proteína é degradada no rúmen é determinada pela atividade proteolítica microbiana, taxa de reciclagem no rúmen e a oportunidade de acesso do microrganismo ao nutriente (NRC, 1985), sendo este último fator também determinado pela permanência do alimento no rúmen. Desta forma, para a predição da extensão de degradação dos nutrientes, é necessário o conhecimento das taxas de passagem e de degradação do alimento, que aplicadas ao modelo de Ørskov e McDonald (1979), permitem estimar a quantidade de energia e proteína efetivamente disponíveis para degradação ruminal.

O NRC (2001) para bovinos leiteiros adotou o método in situ para identificar e estimar as três frações nitrogenadas, definidas como $\mathrm{A}, \mathrm{B}$ e $\mathrm{C}$, e a taxa de degradação $\left(k_{d}\right)$ da fração $B$, onde: A representa o NNP, a proteína rapidamente solubilizada e a proteina presente no alimento em partículas 
menores que a porosidade do saco de nylon/poliester usados nos ensaios; B corresponde à proteína potencialmente degradável, a qual é dependente da taxa de degradação $\left(K_{d}\right)$ e da taxa de passagem $\left(K_{p}\right)$. A fração $C$ é definida como sendo a fração de proteína remanescente na sacola ao fim da incubação, que corresponde ao resíduo resistente à degradação ruminal.

A metodologia in situ para estudo da degradabilidade da proteína apresenta grandes variações entre laboratórios. As principais fontes de erro, e que requerem padronização metodológica são: tamanho de partícula, tamanho do saquinho e poros, além do material usado para confeccionar os sacos (Vanzant et al. 1998; Broderick \& Cochran, 2000).

Segundo revisão feita por Vanzant et al. (1998) e mais recentemente por Broderick \& Cochran (2000), uma das principais fontes de erro da técnica in situ é a contaminação microbiana do resíduo, podendo levar a sub estimativas da degradabilidade da matéria seca (MS), e principalmente da PB.

\subsection{Contaminação microbiana do resíduo da incubação ruminal}

A degradabilidade in situ apresenta, muitas vezes valores viciados em função da contaminação microbiana dos resíduos alimentares, subestimando a degradação protéica dos alimentos (Mathers \& Aithicson, 1981).

Dixon \& Chanchai (2000) e Beckers et al. (1995) relatam que as digestibilidade da matéria seca e da proteína são significativamente subestimadas quando não são feitas as correções para contaminação microbiana. Segundo Dixon \& Chanchai (2000), a proporção de N microbiano/N total no resíduo pode variar de 54 a $69 \%$ (6 e $24 \mathrm{~h}$ ) para feno de alfafa e de 76 a $85 \%$ ( 6 e $24 h$ ) para palha de cevada.

A adesão bacteriana dos alimentos quando expostos ao ambiente ruminal comporta-se de maneira diferente, principalmente devido à composição química de cada ingrediente em particular, sendo que alimentos mais fibrosos e com 
menor teor de $\mathrm{N}$ tendem a apresentar maior proporção de $\mathrm{N}$-bacteriano (Wanderley et al. 1993; Beckers et al. 1995; Perez et al., 1996).

Várias são as técnicas que podem ser utilizadas para a determinação da contaminação microbiana. As mais utilizadas são as técnicas do ácido diaminopimélico (DAPA) (Ling \& Buttery, 1978) e derivados de purinas (Zinn \& Owens, 1986) como marcadores internos, e a diluição isotópica através da técnica do ${ }^{15} \mathrm{~N}$ como marcador externo (Broderick \& Merchen, 1992).

A técnica do DAPA apresenta limitações, pois este composto está presente em alguns alimentos (Von Keyserlingk et al., 1996), apresentando alta variabilidade nos resultados e superestimando a proteina microbiana (Sadik et al., 1990) além de ser degradado no rúmen (Masson, et al., 1991). Segundo Broderick \& Merchen (1992), baseando-se em diversos trabalhos que narram a síntese de proteina microbiana, esta técnica não é adequada para quantificar o crescimento microbiano.

Os marcadores microbianos devem apresentar as seguintes características: 1) não estar presente no alimento; 2) não ser absorvido; 3) ser biologicamente estável; 4) fácil metodologia de determinação, 5) ocorrer similarmente entre os microrganismos e 6) ser constante na célula em todos os estágios de crescimento. Baseando-se em vários trabalhos Broderick e Merchen (1992) afirmam que os derivados de purinas e a técnica do isótopo estável do ${ }^{15} \mathrm{~N}$ satisfazem a maioria destas exigências.

Trabalhos realizados por Wanderley et al. (1993), Varvikko et al. (1983) e a revisão feita por Broderick \& Merchen (1992), indicam que a técnica da diluição isotópica do ${ }^{15} \mathrm{~N}$ é aplicável para estimar a colonização do resíduo, usando correções para estimar a degradabilidade da MS e do nitrogênio dos alimentos com maior precisão.

Por definição, isótopos são átomos de um mesmo elemento químico onde existe uma diferença no número de nêutrons no núcleo mas com mesmo número de prótons (Trivellin, 1990). Os isótopos podem ser estáveis, que não emitem radiações, ocorrendo na natureza em proporções quase constantes. Da 
mesma forma podem ocorrer de maneira natural os radio-isótopos, ou seja isótopos radioativos que emitem radiaçōes (Alfa ou Beta), assim como é possivel a produção de tais elementos de maneira artificial. Portanto nem todo isótopo é radioativo.

A abundância isotópica de isótopos estáveis dos elementos ocorre na natureza em proporções quase que constantes, sendo a do ${ }^{14} \mathrm{~N}$ de $99,634 \%$ e do ${ }^{15} \mathrm{~N}$ de $0,366 \%$ (Trivelin, 2002). Os isótopos pesados são usados como traçadores em diversos tipos de estudos, usando-se elementos com proporções de isótopos diferentes daquela da ocorrência natural (compostos enriquecidos com isótopo pesado).

Trabalhos realizados por Wanderley et al. (1993), Varvikko et al.(1983) e na revisão feita Broderick \& Merchen (1992) indicam que a técnica da diluição isotópica é aplicável para estimar a correção da colonização do resíduo, e estimar a degradabilidade da MS e do nitrogênio dos alimentos com maior precisão.

Para a estimativa da contaminação microbiana através da técnica de diluição isotópica do ${ }^{15} \mathrm{~N}$ (Broderick \& Merchen, 1992), pode ser feita através da infusão ruminal diária (continua ou pulso) de ${ }^{15} \mathrm{~N}$ na forma de sulfato de amônio $\left(\left({ }^{15} \mathrm{NH}_{4}\right)_{2} \mathrm{SO}_{4}\right)$, devendo ser mantida até ao final das incubações. A incubação dos saquinhos deve ser feita após a o enriquecimento atingir o platô às $48 \mathrm{~h}$, (Beckers et al., 1995). Amostras do conteúdo ruminal devem ser tomadas para separação das bactérias associadas às fases sólida e líquida (BAS e BAL) para determinação do enriquecimento.

Outra forma de determinar a contaminação microbiana é a incorporação do $15 \mathrm{~N}$ como marcador interno das plantas a serem usadas, através da fertilização nitrogenada de produtos enriquecidos (Varvikko et al., 1983; Wanderley et al., 1993), possibilitando redução nos custos com o marcador. A contaminação microbiana é determinada após a incubação ruminal também através da diluição isotópica. Entretanto Broderick \& Merchen (1992) relatam que tal metodologia pode subestimar a contaminação microbiana, em função da 
possibilidade das bactérias incorporarem o $15 \mathrm{~N}$ do alimento, estando aderidas ao mesmo.

Beckers et al. (1995) avaliaram a contaminação microbiana do farelo de soja, farelo de trigo e farinha de ossos e carne em vários tempos de incubação ruminal, utilizando a técnica da diluição isotópica com ${ }^{15} \mathrm{~N}$. A contaminação microbiana do farelo de soja e do farelo de trigo aumentou linearmente com o tempo de incubação até 32 e $50 \%$ Nbact (\% nitrogênio bacteriano no resíduo) com o tempo de incubação de $48 \mathrm{~h}$. A farinha de ossos e carne manteve valores constantes de colonização ( $5 \%$ Nbact) durante o período de incubação ruminal. Os autores relataram diferenças para todos os alimentos entre a degradação aparente e a corrigida.

Dixon \& Chanchai (2000), trabalhando com carneiros, observaram interação entre fonte de alimento e tempo de incubação ruminal para a colonização microbiana do resíduo através da técnica do ${ }^{15} \mathrm{~N}$. Os autores, assim como Beckers et al. (1995) relatam que a digestibilidade da MS e da proteína são significativamente subestimadas quando não são feitas as correções.

A técnica de diluição isotópica com ${ }^{15} \mathrm{~N}$ como marcador microbiano é a de maior precisão para determinação da sintese de proteína microbiana ou contaminação da proteína microbiana, pois é um composto de fácil assimilação pela bactéria, sendo distribuído de forma homogênea (Broderick e Merchen, 1992). Porém, assim como outros marcadores, as vantagens esbarram quando se diz respeito a protozoários, pois estes apresentam concentrações de $\mathrm{N}$ e enriquecimentos de ${ }^{15} \mathrm{~N}$ diferentes.

\subsection{Aminoácidos para ruminantes}

Animais ruminantes e não ruminantes necessitam receber quantidade adequadas de aminoácidos essenciais nos tecidos para atender as suas exigências de crescimento e ou produção. Estas exigências são influenciadas por diferentes fatores, como genótipo, sexo, ambiente, tipo de produção (leite 
ou carne) e estádio fisiológico. As diferenças nas quantidades de aminoácidos exigidos, não alteram o seu perfil. Assim as alterações nas exigências podem referir-se a quantidade de proteína balanceada, ou proteina ideal (Boisen et al., 2000).

Segundo Boisen et al. (2000), a proteína ideal pode ser definida como "a perfeita relação entre os aminoácidos essenciais e o $\mathrm{N}$ exigido para o ótimo desempenho". Segundo os autores, a aplicação do conceito de proteína ideal na formulação de ração para animais de produção é uma ferramenta importante na diminuição não só na quantidade de $\mathrm{N}$ na dieta, mas como também na excreção deste composto via fezes e urina.

Dietas podem ser facilmente formuladas para satisfazer as exigências de aminoácidos e energia para animais monogástricos. Por outro lado, quando se trata de ruminantes a tarefa é mais difícil, pois o suprimento de aminoácidos para absorção no duodeno dos ruminantes é uma mistura da proteína do alimento que escapa à degradação e da proteína produzida no rúmen. $A$ alteração na estrutura do alimento, e a eficiência com que isto é feito no rúmen, não é constante entre as dietas (Boisen et al., 2000).

A proteína de origem microbiana é de alta qualidade pois possui o perfil de aminoácidos semelhante ao do tecido animal e leite, porém muitas não é capaz de satisfazer as exigências de novilhos com elevadas taxas de crescimento, e o desempenho pode ser menor que o esperado, a não ser que sejam fornecidos aminoácidos de origem "não microbiana" (O'Connor et al., 1993; NRC, 2000; Beermann et al., 1998, Kunkle \& Hopkins, 1999).

A estimativa do perfil de aminoácidos disponiveis para absorção intestinal em bovinos, feita pelo Cornell Net Carbohydrate and Protein System (CNCPS), depende de estimativas da composição dos aminoácidos essenciais (metionina (Met), lisina (Lis), histidina (His), fenilalanina (Fen), triptofano (Trp), treonina (Tre), leucina (Leu), isoleucina (Iso), valina (Val), e arginina (Arg)) disponiveis na proteína microbiana e na proteína dietética resistentes à degradação no rúmen (O’Connor et al., 1993). 
A suplementação de fontes de proteína (verdadeira e não verdadeira) para ruminantes visa suprir as exigências de nitrogênio ruminal para síntese de proteina microbiana, e fornecer aminoácidos essenciais para a absorção intestinal (Ludden \& Cecava, 1995).

Bovinos em crescimento têm alta deposição de proteina nos tecidos, e conseqüentemente, altos requerimentos de aminoácidos digestíveis. Nestas condições, os requerimentos não podem ser satisfeitos somente por proteína de origem microbiana, havendo a necessidade de suplementar com proteína não degradada no rúmen, aumentando o fluxo total e alterando o perfil de aminoácidos para o intestino delgado (NRC, 1985; Merchen \& Titgemeyer, 1992; Ludden et al.,1995, Schwab, 1996).

Para a ótima deposição de proteína no tecido muscular é necessária a absorção intestinal adequada não só na quantidade mas o perfil ideal de aminoáciodos. Qualquer desbalanço no perfil, ou deficiência de um único aminoácido na dieta, vai limitar o crescimento animal (Merchen e Titgemeyer, 1992). Esse desbalanceamento está provavelmente relacionado com a competição de absorção entre aminoácidos que compartilham do mesmo tipo de transporte tanto para entrar como para sair do enterócito. Além da competição entre aminoácidos, existe a competição entre aminoácidos e peptídeos (di e tri), pois esses possuem uma maior taxa de absorção, contribuindo para uma menor absorção intestinal dos aminoácidos devido a concentração interna ser maior que a concentração externa do enterócito (Fox \& Tedeschi, 2003).

A Met, Cis, Lis, His, e possivelmente a Tre, Val e Iso, podem ser limitantes ou co-limitantes para o crescimento satisfatório de bovinos de corte (Merchen \& Titgemeyer, 1992). Poppi \& Mclennan (1995) relatam que Met, Lis, His, Arg, Trp e Cis são os principais aminoácidos que limitam o desempenho de bovinos, provavelmente devido a composição de aminoácidos dos tecidos.

A lisina e metionina são os aminoácidos mais limitantes para vacas em lactação (Rulquin \& Vérité, 1996; Schwab et al. 1996) e para animais em 
crescimento sugere-se além destes, a treonina como sendo o terceiro aminoácido limitante (Richardson \& Hatfield, 1978; Church, 1990). Entretanto, essas limitações dependem da dieta, tipo de animal, ambiente, e outros fatores inerentes ao animal. Por exemplo, tem-se demonstrado que His é limitante em animais em pastejo ao passo que Met geralmente é limitante em animais em confinamento.

Vários trabalhos relatam que a metionina é o principal amino ácido limitante para o crescimento de bovinos de corte (Merchen \& Titgemeyer, 1992; Wilkerson et al., 1993; Kunkle \& Hopkins, 1999). Por outro lado, ao suplementar apenas metionina, não há suficiente melhorar dos ganhos, ou no balanço de nitrogênio, devido ao desbalanço no perfil de aminoácidos. Porém ao utilizar misturas de aminoácidos essenciais adequadamente balanceados as respostas em ganhos são superiores (Merchen \& Titgemeyer, 1992; Poppi \& Mclennan, 1995). Löest et al (2001) demonstraram que leucina e valina foram limitantes quando a proteína microbiana era a única fonte de proteína metabolizável para bovinos. Esse fato por estar relacionado às deficiências de ácidos graxos ramificados em nivel ruminal (Tedeschi et al., 2000b), devido a menor degradabilidade destes aminoácidos em relação aos demais, independente do tipo de alimento (Varvikko, et al., 1986; Erasmus et al., 1994; Harstad e PrestØKen, 2000; Miranda, 2002) .

Sloan et al. (1998) recomenda o uso de $6,82 \%$ e $2,19 \%$ de proteína metabolizável para os respectivos teores de lisina e metionina digestiveis, no balanceamento de misturas para vacas em lactação. Schwab (1996) considera que os teores de lisina e metionina na digesta duodenal devem ser de 14,7 a 16,7 e de 5,3 a $5,6 \%$ do total de aminoácidos essenciais, respectivamente, semelhante às proposições de Rulquin \& Vérité (1993) de 15 e de $5 \%$ de lisina e metionina (\% do total de aminoácidos essenciais) na digesta duodenal. Sempre deve ser respeitada a relação de 3:1 entre lisina e metionina (Rulquin e Vérité, 1993; Schwab, 1996; Sloan et al., 1998). Quando dietas são formuladas para fornecimento de lisina e metionina de acordo com os autores supra 
citados, observam-se aumentos significativos na produção e no teor de proteina do leite. Por outro lado, respostas negativas são observadas na produção de leite e consumo de matéria seca quando há excesso de metionina em relação a lisina (Garthwaite et al., 1998).

Segundo Schwab et al. (1993), o balanço perfeito de aminoácidos absorvidos no duodeno é o fator mais importante para aumentar a produção de proteína láctea do que o teor de proteína na dieta. Fato este também foi constatado por Bach et al. (2000), onde vacas recebendo dietas com $15 \%$ de proteína, mas com balanço adequado de aminoácidos, apresentaram produções de leite e de proteína láctea semelhantes às vacas recebendo dietas com $18 \%$ de $\mathrm{PB}$, mas com balanço de aminoácidos inadequado. Isto implica que o correto balanceamento de aminoácidos promove o uso mais eficiente de $\mathrm{N}$ na síntese de proteina do leite.

Wilkerson et al. (1993) sugerem que as exigências de aminoácidos em relação às de proteína metabolizável, para bovinos de corte em crescimento, são de $3,0 \%$ de metionina, $8,0 \%$ de lisina, $1,0 \%$ triptofano, $5,2 \%$ treonina, $5,7 \%$ valina, $6,9 \%$ leucina, $3,9 \%$ fenilalanina e $1,6 \%$ de histidina. A relação entre lisina e metionina foi de $2,7: 1$, sendo bem próximo das relações de $3: 1$ sugeridas para vacas leiteiras.

Alguns autores afirmam que a composição de aminoácidos da proteína microbiana é constante, e independentemente da dieta oferecida ao animal (Varvikko, 1986; Von Keyserlingk et al., 1996). Sendo assim, qualquer alteração na composição de aminoácidos da digesta duodenal irá ocorrer devido ao perfil de aminoáciodos do alimento que escapa a degradação ruminal. Por outro lado, Clark et al. (1992) relatam que a composição química de bactérias isoladas no rúmen de vacas podem diferir de maneira significativa em função da dieta.

Quando a quantidade de proteína não degradada no rúmen é aumentada, o balanço de aminoácidos desta parcela se torna muito importante, indicando que a seleção e combinação de várias fontes são importantes para assegurar a 
absorção com um adequado balanceamento de aminoácidos (Wilkerson et al., 1993; Palmiquist et al., 1993; Maiga et al., 1996).

Desta forma ao preconizar o incremento de aminoácidos na dieta para ruminantes, deve-se considerar: a degradabilidade da proteína do alimento no rúmen; o conteúdo de aminoácidos da proteína não degradável no rúmen; e a digestibilidade intestinal dos aminoácidos da proteína não degradada no rúmen (Mupeta et al., 1997). Também deve ser considerado que a degradação dos alimentos ocorrida no rúmen pode alterar o perfil de aminoácidos, quer no aspecto qualitativo ou quantitativo, em relação a composição original do alimento (Oldhan, 1993; Cozzi et al., 1995; Beermann et al., 1998). Entretanto, Tedeschi et al. (2001) não encontraram diferenças entre o perfil de aminoácidos de forragens e de seus resíduos após tratamento com tampão de boratofosfato, que é utilizado para estimar a quantidade de proteina solúvel no ambiente ruminal.

A diminuição da degradabilidade dos aminoácidos da proteína está relacionada ao tratamento físico-químico dos alimentos (Prestøkken, 1999; Harstad e Prestløkken, 2000), ou pelo aumento na proporção de concentrado na dieta que resulta em aumento da taxa de diluição (NRC, 1985; Church, 1988).

Harstad e Prestløkken (2000) avaliaram a degradabilidade intestinal e ruminal do farelo de soja e da soja tratada com xilose (SoyPass ${ }^{\circledR}$ ). A degradabilidade ruminal efetiva dos aminoácidos totais foram respectivamente de 53,3 e $28,7 \%$.

Lycos e Varga (1995) realizaram estudo para determinar efeitos do tamanho da particula e tratamento pelo calor na degradação cinética dos aminoácidos na soja crua, quebrada, moída e tostada. O tratamento pelo calor diminuiu a degradabilidade e o padrão de degradação fracionada no rúmen para todos os aminoácidos, exceto para lisina, porém a redução do tamanho da partícula teve efeito contrário. Metionina, leucina e treonina foram os aminoácidos que apresentaram menor degradação. Os autores também 
relataram diferenças no perfil de aminoácidos no alimento após a incubação ruminal.

Prestløkken (1999) trabalhando com cevada e aveia, e Von Keyserlingk et al. (1996) avaliando 19 silagens de gramíneas, concluiram que a degradação ruminal da proteína e dos aminoácidos totais não podem ser usadas para determinação da degradação ruminal de aminoácidos individuais, pois estes apresentaram diferentes taxas de degradação ruminal. Prestløkken (1999) ainda observou que a arginina, ácido glutâmico, cisteína e histidina têm maior degradabilidade, enquanto que isoleucina, leucina, metionina, tirosina, valina, e fenilalanina, têm menor degradação.

Os aminoácidos essenciais, segundo Varvikko et al. (1986), têm degradação mais lenta que os não essenciais, aumentando as proporções relativas dos essenciais. Os aminoácidos de cadeia ramificada (isoleucina, leucina e valina) são mais resistentes à degradação microbiana que os outros aminoácidos (Varvikko, 1986).

Ao avaliar os efeitos do nivel de ingestão de dietas com proteínas de diferentes degradabilidade, Volden (1999) observou alterações no fluxo duodenal de aminoácidos. Nas dietas com fontes protéicas de menor degradabilidade houve maior fluxo duodenal de aminoácidos totais. Nos menores níveis de ingestão de concentrado houve aumento nas proporções de cistina, isoleucina, ornitina, e histidina, enquanto que o conteúdo de metionina diminuiu. Concluiu-se que o nivel de ingestão e a quantidade de proteína não degradável no rúmen alteraram a quantidade e a composição do fluxo de aminoácidos para o intestino.

Em outro ensaio, Volden et al. (1998) estudou a cinética da lisina, metionina e treonina após infusão intra-ruminal em vacas lactentes, com dois niveis de ingestão de alimento. Com o aumento na dosagem, todos os aminoácidos mostraram diminuição linear na degradação ruminal. $A$ taxa de degradação relativa da metionina foi menor que a da lisina para o maior nível de 
ingestão, por outro lado o menor nível de ingestão resultou na maior degradação da metionina.

Crooker et al. (1987) alimentaram vacas em lactação com dietas mistas (25\% silagem de milho, $25 \%$ feno de alfafa, $50 \%$ mistura de grãos com sete suplementos protéicos) e utilizaram-se do DAPA (ácido diaminopimélico) como marcador da contaminação microbiana. Os autores concluíram que a fermentação ruminal altera o perfil de aminoácidos do resíduo após incubação em relação ao alimento original. A determinação da extensão dessas alterações em função do tempo, assim como a taxa de proteina sobre passante, permitirá estimar a contribuição da dinâmica dos aminoácidos da dieta no intestino.

Cozzi et al. (1995) revisou que há diferenças nas taxas de degradação de aminoácidos específicos in vitro e in vivo, indicando a remoção seletiva pelos microrganismos ruminais. Em alguns trabalhos (Varvikko et al., 1983; Weakley et al., 1983 e Maiga et al., 1996) o perfil de aminoácidos dos resíduos após exposição ruminal continuavam semelhantes aos do alimento original. Outros trabalhos (Cozzi et al., 1995; Crooker et al., 1986 e Von Keyserlingk et al. 1998) que avaliaram a composição de aminoácidos nas frações de proteína não degradáveis no rúmen, após correção para contaminação microbiana do resíduo, observaram diferenças no perfil de aminoácidos entre a proteína ingerida e a proteína não degradada no rúmen.

Maiga et al. (1996) incubaram por $12 \mathrm{~h}$ amostras de farinha de sangue, glúten de milho, farelo de soja e farinha de ossos e sangue. Os autores relatam que não houve diferença entre o perfil de aminoácidos do alimento e do resíduo. Isto, segundo os autores, pode ter ocorrido em função da contaminação de aminoácidos de origem microbiana, já que não foram feitas as correções por marcadores.

Foi avaliada a degradação de aminoácidos, corrigindo para contaminação microbiana, após periodo de incubação de quatro fontes de proteina no rúmen de vacas Holandesas. Cozzi et al. (1995) concluíram que o padrão de desaparecimento dos aminoácidos é diferente entre os alimentos. $A$ 
degradação ruminal modificou a concentração dos aminoácidos essenciais em relação à proteína original. Isto indica a necessidade da determinação do perfil de aminoácidos nas frações não degradadas do rúmen, pois a utilização dos aminoácidos do alimento para estimar a absorção intestinal não é precisa.

Varvikko (1986) trabalhando com amostras de alimentos marcadas com ${ }^{15} \mathrm{~N}$, e utilizando a técnica de diluição isotópica, quantificou a contaminação microbiana das amostras após incubação ruminal. Os autores concluíram que o ambiente ruminal altera a composição de aminoácidos do alimento original.

As observações feitas por Varvikko (1986), Crooker et al. (1986), Cozzi et al. (1995) e Von Keyserlingk et al. (1996) indicam a necessidade do uso de marcadores microbianos para a correta determinação do perfil de aminoácidos das frações da proteina não degradável no rủmen.

Para que o ajuste de proteína visando as exigências de aminoácidos nas dietas para bovinos de corte tenha a mesma precisão que em monogástricos, é necessário detalhar o perfil de aminoácidos de alimentos disponíveis para digestão intestinal sob diferentes condições de rúmen. Modelos como o CNCPS vem sendo desenvolvidos para determinar as exigências e as proporções de aminoácidos para absorção intestinal. Desta forma, há uma necessidade de detalhar informações sobre a composição dos alimentos. Dados na literatura sobre alimentos para bovinos utilizados no Brasil ainda são escassos.

O objetivo desse estudo foi de avaliar o efeito da proporção de concentrado da dieta no tempo de colonização, nas características da fermentação ruminal, na degradação de alimentos concentrados e na composição de aminoácidos da proteína não degradada no rúmen. 
3 EFEITO DA DIFERENTES PROPORÇÕES DE CONCENTRADO NA CONTAMINAÇÃO MICROBIANA PELA TÉCNICA DO ${ }^{15} \mathrm{~N}$ NOS RESÍDUOS dOS ALIMENTOS E NAS CARACTERÍSTICAS DE FERMENTAÇÃO RUMINAL

\section{Resumo}

Foi avaliada a contaminação microbiana nos resíduos de incubação ruminal de alguns alimentos $e$ as características da fermentação ruminal utilizando seis novilhos Nelore, canulados no rumem, alojados em gaiolas de metabolismo e dispostos em Quadrado Latino (3x3) com repetição, recebendo aleatoriamente um das três proporções de concentrado $(20,40,60 \%)$. Os alimentos testados foram: casca de soja, milho, sorgo, farelo de algodão, farelo de soja e farelo proteinoso de milho. Após adaptação, a dose pulso diária de $360 \mathrm{mg}{ }^{15} \mathrm{~N}$ foi inoculada no rúmen por seis dias. Os alimentos foram incubados no rúmen pelo método dos saquinhos de nylon no terceiro dia de infusão durante $3,6,12,24$ e 48h, além de $60 \mathrm{~h}$ para o farelo proteinoso de milho e a casca de soja. O líquido ruminal foi coletado ao final das incubações saquinhos com $0,1,2,3,4,6$ e 8h após a alimentação. Foi observada interação entre alimento e tempo de incubação $(P<0,05)$, para a contaminação microbiana. A contaminação do resíduo de incubação ruminal aumentou, de forma geral, com o tempo de exposição ruminal, sendo que as principais variações ocorreram em relação a \% de nitrogênio bacteriano no resíduo (\%Nbact). O milho, e farelo de algodão e sorgo apresentaram maiores \%Nbact nos tempos de 24 e $48 \mathrm{~h}$ $(P<0,05)$ e o farelo de soja apenas com $48 \mathrm{~h}$. $O$ farelo proteinoso do milho e a 
casca de soja apresentaram maiores \%NBact nos tempos de 24,48 e $60 \mathrm{~h}$ $(\mathrm{P}<0,05)$. O tratamento com $60 \%$ quando comparado com os tratamentos com 20 e $40 \%$ de concentrado apresentou menor valor médio de $\mathrm{pH}(\mathrm{P}<0,05)$, maior produção de AGV's $(P<0,05)$, menor proporção de ácido acético $(P<0,05)$, em decorrência do aumento da proporção molar de ácido propiónico $(P<0,05)$, levando a menores relações entre acético:propiónico $(P<0,05)$, e maior proporção molar de ácido butírico $(P<0,05)$,e menor concentração $\mathrm{N}-\mathrm{NH}_{3}$ $(\mathrm{P}<0,05)$.

Effects of different concentrate ratios on bacterial contamination with ${ }^{15} \mathrm{~N}$ technique of feed residues and rumen fermentation characteristics.

\section{Summary}

Six rumen cannulated Nelore steer were used in replicated latin square design $(3 \times 3)$, with the objective of analyze the effects of different ratios of concentrate $(20,40,60 \%)$ on microbial contamination of incubated feed residues with ${ }^{15} \mathrm{~N}$ stable isotope technique and ruminal fermentative characteristics. The tested feed were soy bean hulls, corn, sorghum grain, soy bean meal, cottonseed meal and corn gluten feed. After 8 days of adaptation period, a daily pulse dose of $360 \mathrm{mg}{ }^{15} \mathrm{~N}$ were infused into the rumen during 6 days. The feed were incubated in the rumen using the nylon bag technique starting on the third day of infusion during 3, 612,24 and 48h, and an extra period of $60 \mathrm{~h}$ for corn gluten feed and soy bean hulls. Rumen liquor were collected at $0,1,2,3,4,6$ and $8 \mathrm{~h}$ post feeding. There was an interaction among feed and incubation period $(P<0,05)$ for microbial contamination. The residue contamination increased with rumen exposure for all feeds, and the main variations detected were with $\%$ o residual bacterial nitrogen (\%Nbact). The corn, cottonseed meal and the sorghum showed higher \%Nbact after 24 and $48 \mathrm{~h}$ of rumen exposure, and the soy bean meal only after $48 \mathrm{~h}$. The corn gluten 
feed and soy bean hulls had the largest \%Nbact contamination after 24,48 and $60 \mathrm{~h}$ of rumen exposure. The treatment with $60 \%$ of concentrated, when compared with 20 and $40 \%$ had lower mean $\mathrm{pH}(\mathrm{P}<0,05)$, higher volatile fatty acids production $(P<0,05)$, lower acetic acid proportion $(P<0,05)$, because of a increased proportion of propionic acid $(P<0,05)$, which caused a lower ratios of acetate:propionate $(P<0,05)$, higher molar proportion of butyric acid $(P<0,05)$, and lower rumen ammonia nitrogen $\left(\mathrm{N}-\mathrm{NH}_{3} ; \mathrm{P}<0,05\right)$.

\subsection{Introdução}

A digestão ruminal é um sistema anaeróbio e dinâmico envolvendo microorganismos, como bactérias, protozoários e fungos. Para tal, a adesão microbiana a superfícies é muito importante no qual tem numerosas implicações em um ecossistema onde é constante a introdução e remoção de material (Church, 1990). A adesão bacteriana aos alimentos, quando expostos ao ambiente ruminal, comporta-se de maneira diferente em função da composição química de cada ingrediente, sendo que alimentos mais fibrosos e com menor teor de nitrogênio tendem a apresentar maior proporção de nitrogênio bacteriano (Wanderley et al. 1993; Beckers et al. 1995; Perez et al., 1996). Dixon e Chanchai (2000) relatam que a proporção de $\mathrm{N}$ microbiano/ $\mathrm{N}$ total no resíduo pode variar de 54 a $69 \%$ ( 6 e $24 \mathrm{~h}$ ) para feno de alfafa e de 76 a $85 \%$ (6 e 24h) para palha de cevada. A capacidade de adesão dos microrganismos ao resíduo podem ser influenciadas por fatores como temperatura, $\mathrm{pH}$ e produtos finais da digestão do substrato (Church, 1990).

A técnica de saquinho de nylon para avaliação da degradabilidade in situ é a ferramenta usada em diversos estudos para estimar a disponibilidade e a cinética da degradação de substratos no rúmen. Entretanto, a degradabilidade in situ apresenta, muitas vezes, valores viciados em função da contaminação microbiana dos resíduos alimentares, subestimando a degradação protéica dos alimentos (Mathers \& Aithinson, 1981). Dixon \& Chanchai (2000) e Beckers et 
al. (1995) relatam que as degradabilidade da matéria seca e da proteína são significativamente subestimadas quando não são feitas as correções para contaminação microbiana. Várias são as técnicas que podem ser utilizadas para a determinação da contaminação microbiana. As mais utilizadas são as técnicas que usam o ácido diaminopimélico (DAPA) (Ling \& Buttery, 1978), derivados de purinas (Zinn \& Owens, 1986) como marcadores internos e a diluição isotópica através da técnica do ${ }^{15} \mathrm{~N}$ como marcador externo (Broderick \& Merchen, 1992). Trabalhos realizados por Wanderley et al. (1993), Varvikko et al. (1983) e em revisão feita por Broderick e Merchen (1992) indicam que a técnica da diluição isotópica do ${ }^{15} \mathrm{~N}$ é aplicável para estimar a colonização do resíduo, possibilitando correções para estimar a degradabilidade da MS e do nitrogênio dos alimentos com maior precisão

Como resultado do processo de fermentação microbiana do substrato temse a produção de metabólitos, os ácidos graxos voláteis (AGV's) e lactato, principais responsáveis pela diminuição do pH ruminal. Os AGV's (ácido acético, ácido propiónico e ácido butírico) são absorvidos por difusão através da parede ruminal, participando do metabolismo energético dos animais como principais fontes de energia (50 a 70\%; Church, 1990; Van Soest, 1994; Allen, 1997). A inclusão de concentrado na dieta, e consequentemente maior disponibilidade de amido para degradação ruminal, causa um aumento na concentração total de ácidos graxos voláteis (Chen, 1994), com alteração nas proporções, principalmente com aumento de ácido propiónico, e redução de ácido acético, e consequentemente redução na proporção acetato:propionato (Church, 1990; Vanzant et al., 1990; Chen, 1994; Theurer et al., 1996).

Para que este processo de fermentação e digestão seja eficiente, em função da otimização do crescimento/atividade microbiana, deve-se garantir um balanço de adequado de $\mathrm{N}$ (Tedeschi et al., 2000a) e pH adequado (Dixon \& Stockdale 1999). Para a otimização da digestão da fibra a concentração nitrogênio amoniacal $\left(\mathrm{N}-\mathrm{NH}_{3}\right)$ no rúmen deve estar entre 2,0 a 5,0 mg/dl (Satter e Roffler (1979) e em relação ao pH, a digestão da fibra é intensamente 
reduzida quando for inferior a 6,2, e mínima, quando os valores apresentados forem inferiores a 6,0 (Dixon \& Stockdale, 1999)).

Bactérias celulolíticas usam basicamente apenas amônia como fonte de nitrogênio, e sua capacidade fermentativa é consideravelmente reduzida na ausência de $\mathrm{N}-\mathrm{NH}_{3}$, já que sua capacidade de usar $\mathrm{N}$ na forma de aminoácidos e peptídeos é bastante reduzida. Já as bactérias amilolíticas apresentam crescimento mais rápido, utilizando cerca de $64 \%$ de peptídeos e aminoácidos e 34 \% de amônia, como fontes de N para seu crescimento (Bryant, 1973; Russell et al., 1992). Além disso, as bactérias que degradam amido, pectina ou açúcares são capazes de continuar a degradação do substrato mesmo quando $\mathrm{N}$ é limitante (Tedeschi et al., 2000a), ao passo que as bactérias que degradam fibra não. Esse fenômeno é conhecido como "energy spilling" ou gasto inútil de energia. Por outro lado, os microrganismos dependem da energia oriunda da fermentação dos carboidratos para que a biosíntese de proteína microbiana, caso contrário os peptídeos e aminoácidos passam a ser utilizados como fontes de energia, ocorrendo acúmulo de amônia no meio (Russell et al., 1992). Desta forma, a concentração de $\mathrm{N}-\mathrm{NH}_{3}$ no rúmen depende da degradabilidade da fonte protéica e da disponibilidade de carboidratos (Satter \& Roffler, 1979, Nocek \& Russell, 1988) e do equilibrio entre sua produção e utilização pelos microrganismos.

O objetivo do presente trabalho foi determinar os efeitos das diferentes proporções de concentrado na adesão microbiana em resíduos de alimentos após a incubação ruminal, utilizando-se da técnica do isótopo do ${ }^{15} \mathrm{~N}$ e as variações nos parâmetros de fermentação ruminai. 


\subsection{Material e métodos}

\subsubsection{Animais e dieta experimental}

O trabalho foi realizado na Estação Experimental Central do Instituto de Zootecnia, localizado no município de Nova Odessa, SP. Foram utilizados seis bovinos Nelore providos de fistula ruminal com peso inicial de aproximadamente $380 \mathrm{~kg}$, alojados em gaiolas de metabolismo, em um delineamento do tipo Quadrado Latino $3 \times 3$, com duas repetições por tratamento em cada período. No primeiro período experimental os 6 animais foram distribuídos por sorteio para os diferentes tratamentos, sendo 2 animais para cada tratamento, e nos periodos subsequentes os animais mudavam de tratamento.

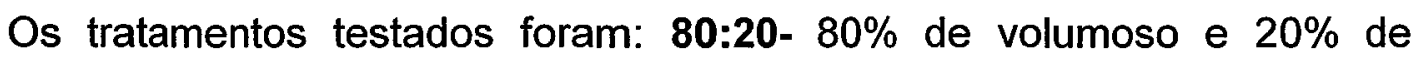
concentrado, $60: 40-60 \%$ de volumoso e $40 \%$ de concentrado ou $40: 60-40 \%$ de volumoso e $60 \%$ de concentrado. O volumoso utilizado foi a silagem de milho, e no concentrado utilizou-se milho triturado, farelo de soja, farelo de algodão, casca de soja, sorgo em grão moído e farelo proteinoso de milho. Os alimentos bem como as proporções de concentrado utilizadas foram escolhidas pois são tipicamente utilizadas em confinamentos no Brasil para bovinos Nelore.

$\mathrm{Na}$ Tabela 1 são apresentadas as composições químicas de cada ingrediente utilizados na formulação das diferentes dietas (Tabela 2), balanceadas em função dos tratamentos.

As dietas foram formuladas com base no "Cornell Net Carbohydrate and Protein System" (CNCPS 4.2; Fox et al., 2000), com a otimização da função ruminal. A quantidade de alimento fornecido foi de $100 \mathrm{~g}$ de $\mathrm{MS} / \mathrm{kg} \mathrm{PVJ}{ }^{0,75}$, sendo realizados ajustes quando necessário, de modo que não ocorressem sobras. A ração foi fornecida em duas refeições diárias as 8:00 e 15:00 horas. 
Tabela 1. Composição química dos ingredientes

\begin{tabular}{lcccccccc}
\hline Alimento & MS & PB & EE & FDN & FDA & $\begin{array}{c}\text { PBFDA } \\
\text { (\%PB) }\end{array}$ & Lig & MM \\
\hline Milho & 87,5 & 10,4 & 4,3 & 25,6 & 5,1 & 6,8 & 1,1 & 1,1 \\
Casca de soja & 89,7 & 13,6 & 3,1 & 69,0 & 51,7 & 3,7 & 2,2 & 4,6 \\
Sorgo & 84,4 & 10,1 & 2,5 & 32,6 & 7,3 & 5,6 & 4,5 & 1,6 \\
F. p. Milho & 90,4 & 25,7 & 3,0 & 44,6 & 10,9 & 10,3 & 1,2 & 5,0 \\
F. soja & 90,3 & 54,5 & 0,7 & 16,6 & 11,6 & 4,3 & 0,8 & 6,5 \\
F. algodão & 92,2 & 37,0 & 1,1 & 51,5 & 33,7 & 9,3 & 14,8 & 5,1 \\
Silagem de milho & 29,1 & $\mathbf{8 , 3}$ & 1,6 & 61,2 & 32,9 & - & 2,7 & 5,3 \\
\hline
\end{tabular}

MS- Matéria seca; PB-Proteína bruta, EE- Extrato etéreo. FDN- Fibra em detergente neutro, FDA- Fibra em detergente ácido, PBFDA-Proteína bruta ligada ao FDA ( $\%$ da PB) Lig.- lignina, MM- matéria mineral, EB- Energia bruta.

Tabela 2. Proporções dos ingredientes e composição química dos concentrados

\begin{tabular}{|c|c|c|c|}
\hline Ingredientes (\%MS) & $80: 20$ & $60: 40$ & $40: 60$ \\
\hline Silagem de milho & 79,6 & 58,5 & 39,4 \\
\hline Farelo de Soja & 3,5 & 3,6 & 5,4 \\
\hline Farelo de grã̃o de milho & 4,2 & 9,4 & 13,5 \\
\hline f. algodão & 2,2 & 3,6 & 4,1 \\
\hline Sorgo em grãos & 2,8 & 8,0 & 13,5 \\
\hline F. proteinoso de milho & 2,1 & 4,7 & 6,1 \\
\hline Cas & 2,8 & 9,8 & 16,2 \\
\hline Uré & 1,3 & 1,0 & 0,5 \\
\hline Mistura Mineral* & 1,5 & 1,4 & 1,4 \\
\hline \multicolumn{4}{|c|}{ Composição química das dietas } \\
\hline MS (\%MO) & 40,7 & 52,8 & 63,7 \\
\hline PB (\%MS) & 15,6 & 17,8 & 16,8 \\
\hline EE (\%MS) & 2,2 & 2,2 & 2,3 \\
\hline FDN (\%MS) & 50,7 & 47,4 & 44,8 \\
\hline FDA (\%MS) & 30,5 & 27,6 & 25,8 \\
\hline MM (\%MS) & 6,2 & 6,0 & 5,4 \\
\hline \multicolumn{4}{|l|}{ Consumo da ração } \\
\hline $\begin{array}{l}\text { KgMS/dia } \\
\text { g/PV }\end{array}$ & $\begin{array}{c}7,9 \\
84,6\end{array}$ & $\begin{array}{c}9,1 \\
97,6\end{array}$ & $\begin{array}{c}9,0 \\
96,5\end{array}$ \\
\hline
\end{tabular}




\subsubsection{Infusão ${ }^{15} \mathrm{~N}$ no rúmen}

Após sete dias de adaptação à dieta foram feitas infusões diárias no rúmen de uma dose pulso com $360 \mathrm{mg}$ de ${ }^{15} \mathrm{~N}$ na forma de $\left({ }^{15} \mathrm{NH}_{4}\right)_{2} \mathrm{SO}_{4} \quad(35,6$ atm\% ${ }^{15} \mathrm{~N} / \mathrm{N}$ total), imediatamente após o fornecimento da ração da manhã, durante seis dias (Broderick e Merchen, 1992).

A incubação dos saquinhos para estudo da degradabilidade iniciou-se três dias após a primeira infusão, quando as bactérias apresentam o máximo do seu enriquecimento (Firkins et al. 1987; Beckers et al. 1995).

\subsubsection{Separação do pool de bactérias do conteúdo ruminal}

No quinto dia de aplicação de ${ }^{15} \mathrm{~N}$ no rúmen e quatro horas após o fornecimento da primeira refeição, foram coletados $500 \mathrm{~g}$ de conteúdo ruminal em cinco pontos diferentes do rúmen, em cada um dos animais. O conteúdo ruminal foi imediatamente misturado a solução salina $0,9 \%$, e homogeneizado em liqüidificador por 20 segundos, sendo em seguida congelado.

A separação das bactérias foi feita segundo metodologia descrita por Cecava et al. (1990). Após descongelamento o conteúdo ruminal era centrifugado a $500 \times \mathrm{g}$ por 20 minutos, o sobrenadante foi novamente centrifugado a $27000 \times \mathrm{g}$ durante 30 minutos. O precipitado (pellet de bactérias) foi coletado e congelado, para liofilização e encaminhados para determinação do ${ }^{15} \mathrm{~N}$.

\subsubsection{Avaliação da contaminação do resíduo de incubação ruminal}

Os saquinhos $(12 \times 21 \mathrm{~cm})$ com porosidade de $50 \mu$ foram preenchidos com aproximadamente 12 gramas de amostras das diferentes fontes alimentares, tendo-se uma relação de tamanho da amostra por área do saquinho de $23,8 \mathrm{mg} / \mathrm{cm}^{2}$, próximo ao intervalo de 10 a $20 \mathrm{mg} \mathrm{cm}$ proposto por 
Nocek (1988). Os saquinhos continham 2 bolas de gude para manter os sacos submersos no rúmen, e uma argola de metal para serem fixados a mosquetão, que estava amarrado a corda de nylon de $50 \mathrm{~cm}$ de comprimento. Os saquinhos eram posicionados e submersos no rúmen em triplicata por $0,3,6,12,24,48 \mathrm{~h}$, sendo que o farelo proteinoso de milho e a casca de soja tiveram um periodo extra referentes a $60 \mathrm{~h}$ de incubação ruminal. As incubações foram feitas imediatamente após fornecimento da ração aos animais. As incubações dos saquinhos foram feitas seguindo os esquema do quadro 1 :

\begin{tabular}{|l|l|}
\hline Dia & Atividade: \\
\hline 1 a 7 & Adaptação as dietas experimentais \\
\hline 8 a 13 & Dosagem de $360 \mathrm{mg}{ }^{15} \mathrm{~N}$. \\
\hline 10 & Incubação dos saquinhos $48 \mathrm{~h}$ e $60 \mathrm{~h}$ \\
\hline 11 & Incubação dos saquinhos $24 \mathrm{~h}$ \\
\hline 12 & $\begin{array}{l}\text { Retirada dos saquinhos } 48 \text { e } 24 \mathrm{~h} \text {, incubação e retirada } \\
\text { dos saquinhos de } 12 \mathrm{~h} \text {, e retirada dos saquinhos de } 60 \mathrm{~h} .\end{array}$ \\
\hline 13 & Incubação e retirada dos saquinhos $3 \mathrm{~h}$ e $6 \mathrm{~h}$. \\
\hline
\end{tabular}

Após a retirada dos sacos, estes foram lavados em lavadora automática por cerca de 20 minutos com 4 enxágües no modo para tecidos delicados, para que a água fluísse incolor. Após lavagem os mesmos foram secos em estufa com ventilação de ar forçada a $60^{\circ} \mathrm{C}$ por 72 horas, sendo em seguida pesados.

\subsubsection{Determinação do ${ }^{15} \mathrm{~N}$ e $\mathrm{N}$ e da contaminação microbiana do resíduo}

As amostras dos resíduos de alimentos após a incubação ruminal ou de bactérias ruminais foram colocadas em capsulas de estanho em auto amostrador, sendo que a quantidade pesada foi a estimada para conter no mínimo $50 \mu \mathrm{g}$ de $\mathrm{N}$ aproximadamente. A combustão total da amostra foi obtida a temperatura de $1700^{\circ} \mathrm{C}$. Os produtos da combustão $\left(\mathrm{CO}_{2}, \mathrm{~N}_{2}, \mathrm{NO}_{2}\right.$ e $\left.\mathrm{H}_{2} \mathrm{O}\right)$ eram levados para um tubo de redução a $600^{\circ} \mathrm{C}$, onde os óxidos de nitrogênio 
eram reduzidos a $\mathrm{N}_{2}$, sendo retido o excesso de $\mathrm{O}_{2}$. Em seguida os gazes foram conduzidos para uma coluna preenchida com perclorato de magnésio $\left[\mathrm{Mg}\left(\mathrm{ClO}_{4}\right)_{2}\right]$ retendo o vapor de água. $\mathrm{O} \mathrm{CO}_{2}$ era retido em uma armadilha de carbosob, e por último uma coluna cromatográfica separava as impurezas do $\mathrm{N}_{2}$. O efluente entrava no espectrofotômetro de massa atômica para analise do $\mathrm{N}$-total e a razão ${ }^{15} \mathrm{~N} /{ }^{14} \mathrm{~N}$ por meio das intensidade das massas atômicas $28\left({ }^{14} \mathrm{~N}^{14} \mathrm{~N}\right), \quad 29\left({ }^{15} \mathrm{~N}^{14} \mathrm{~N}\right)$ e $30\left({ }^{15} \mathrm{~N}^{15} \mathrm{~N}\right)$, sendo calculado automaticamente a abundância de ${ }^{15} \mathrm{~N}$ (\% de átomos).

As determinações foram realizadas no Laboratório de Isótopos Estáveis do CENA /USP, Piracicaba, SP, em espectrômetro de massas contendo analisador automático para nitrogênio, modelo ANCA-SL, da Europa Scientific LTDA (Barrie \& Prosser, 1996).

A contaminação microbiana do resíduo foram calculados da seguinte forma (Beckers et al., 1995):

$\%$ Nbact $=\frac{\left({ }^{15} \mathrm{~N} \% \text { atm no resíduo- }{ }^{15} \mathrm{~N} \% \text { atm no alimento }\right) \times 100}{\left({ }^{15} \mathrm{~N} \% \text { atm no pool bacteriano }-{ }^{15} \mathrm{~N} \% \text { atm no alimento }\right)}$

$\%$ MSbact $=\frac{\% \text { Nbact } \times \% \mathrm{~N} \text { resíduo }}{\% \mathrm{~N} \text { no pool bacteriano }}$

onde:

\%Nbact é a \% de nitrogênio bacteriano no resíduo em relação ao nitrogênio total, \%MSbact é a \% de matéria seca microbiana no resíduo, ${ }^{15} \mathrm{~N} \%$ atm é a $\%$ de átomos de ${ }^{15} \mathrm{~N}$ no residuo, no alimento ou no pool bacteriano.

$\mathrm{O}$ excesso de ${ }^{15} \mathrm{~N}$ no resíduo para cálculo da contaminação microbiana foi calculado assumindo a abundância natural de cada alimento, determinado antes da incubação ruminal. Os valores da abundância natural de ${ }^{15} \mathrm{~N}$ em cada alimento foram de $0,367 \%$ para o farelo de algodão, farelo proteinoso de milho e sorgo, $0,366 \%$ para soja e milho e $0,365 \%$ para casca de soja. 


\subsubsection{Coleta de líquido ruminal}

As coletas de líquido ruminal nos tempos de $0,1,2,3,4,6,8$ horas após a alimentação da manhã, ao término do período de incubação ruminal. Cerca de 500 gramas de conteúdo ruminal foi coletado, em cinco pontos diferentes no rúmen e peneirado em fralda de pano dobrada formando dupla camada.

$\mathrm{O} \mathrm{pH}$ do líquido ruminal era imediatamente aferido após a colheita e filtragem do com potenciômetro digital portátil.

Cerca de $5 \mathrm{ml}$ de líquido ruminal foram acondicionados em 2 tubos de ensaio, e imediatamente congelados. Um dos tubos era destinado as avaliações de ácidos graxos voláteis e outro para nitrogênio amoniacal.

As dietas foram fornecidas apenas pelo periodo da manhã, pois após as coletas de liquido ruminal os animais iniciavam o jejum completo para se submeterem a pesagem no dia seguinte

\subsubsection{Determinação de nitrogênio amoniacal do rúmen}

O princípio da técnica envolve a reação da amônia com hipoclorito e fenol na presença de catalizador (nitroprussiato de sódio) para formar indofenol (reação de Berthelot). A concentração da amônia é diretamente proporcional a absorbância de indofenol medida por colorimetria.

Na preparação das amostras para determinação das concentrações de amônia no líquido ruminal, foram colocados $2 \mathrm{ml}$ de fluido ruminal em tubos de ensaios contendo $1 \mathrm{ml}$ de ácido sulfúrico $1 \mathrm{~N}$ e armazenados sob refrigeração até a realização das análises. As determinações de amônia foram feitas segundo método proposto por Chaney \& Marbach (1962), adaptado para leitura em leitor de microplaca (BIO-RAD, Hercules, CA, EUA) utilizando-se filtro para absorbância de $550 \mathrm{~nm}$. As soluções padrões utilizadas foram de $0 ; 1 ; 2 ; 4 ; 8$; 16; e $32 \mathrm{mg} / \mathrm{dL}$ de amônia. Foram utilizadas alíquotas de $40 \mu \mathrm{l}$ de amostra ou padrão incubados em banho-maria a $37^{\circ} \mathrm{C}$ por 10 minutos, juntamente com 2,5 
$\mathrm{ml}$ de reagente fenol e $2,0 \mathrm{ml}$ de reagente hipoclorito. As amostras foram submetidas ao leitor de microplacas. Somente foram aceitos resultados provenientes de placas com $r^{2}=0,99$ e coeficiente de variação entre duplicatas $\leq 5 \%$.

As avaliações de amônia ruminal foram realizadas no laboratório de análises químicas do Departamento de Nutrição e Produção Animal da Escola Superior de Agricultura "Luiz de Queiroz"/USP.

\subsubsection{Determinação de ácidos graxos voláteis}

Uma alíquota de aproximadamente $100 \mathrm{ml}$ de liquido ruminal foi centrifugada a $3500 \mathrm{rpm}$ por 15 minutos; $1 \mathrm{ml}$ do sobrenadante foi colocado em tubo de ensaio contendo $0,2 \mathrm{ml}$ de ácido fórmico P.A., sendo armazenado à $20^{\circ} \mathrm{C}$ até o momento da análise.

A determinação de ácidos graxos voláteis foi feita, em duplicata, por cromatografia gasosa (Modelo 9001 Gas Chromatograph, Marca Finnigan) equipado com coluna de vidro de 02 metros de comprimento x 1/4", empacotada com 80/120 Carbopack B-DA/4\% Carbowax 20M. Os gases utilizados foram o nitrogênio, como gás de arraste na vazão de $25 \mathrm{ml} /$ minuto, oxigênio, como gás comburente na vazão de $175 \mathrm{ml} /$ minuto, e hidrogênio, como gás combustivel na vazão de $15 \mathrm{ml} /$ minuto. As temperaturas utilizadas para operação foram, do vaporizador $240^{\circ} \mathrm{C}$, da coluna de separação iniciou-se com $175{ }^{\circ} \mathrm{C}$ aumentando $10^{\circ} \mathrm{C}$ por minuto até $205^{\circ} \mathrm{C}$ e detector de ionização de chamas $260{ }^{\circ} \mathrm{C}$, segundo método preconizado por Erwin et al. (1961), no laboratório de analises químicas do Departamento de Nutrição e Produção Animal (VNP) da Faculdade de Medicina Veterinária da Universidade de São Paulo (FMVZ-USP), campus Pirassununga".

As determinações foram realizadas injetando-se 01 micrometro de amostra em cromatografo, integrado a um computador, que processava os 
cálculos de quantificação, utilizando-se do software BORWIN versão 1.21 para cromatografia.

\subsubsection{Análise Bromatológica}

As amostras dos alimentos determinadas para os seguintes componentes: matéria seca a $105^{\circ} \mathrm{C}(\mathrm{MS})$, matéria mineral (MM), extrato etéreo (EE), proteína bruta (PB) através do método micro Keejdahl (A.O.A.C.,1990), fibra detergente neutro (FDN) e fibra detergente ácido (FDA; Van Soest, et al, 1991).

\subsubsection{Analise estatística}

A análise estatística da contaminação microbiana e das características de fermentação ruminal foram realizadas através da análise de medidas repetidas pelo procedimento Mixed do programa computacional Statistical Analysis System (SAS Institute Inc., 1999), testando-se efeitos de alimento, tempo e suas interações. A comparação das médias foi feita através do teste de tukey ajustado.

\subsection{Resultados e discussão}

A proporção de ${ }^{15} \mathrm{~N}$ e o teor de $\mathrm{N}$ encontrado no pool bacteriano após 4 dias da infusão foi em média de $0,527 \%$ e $6,71 \%$ da MS, respectivamente, não havendo diferenças significativas entre tratamentos e períodos (Tabela 3). A abundância natural do isótopo ${ }^{15} \mathrm{~N}$ é de $0,366 \%$, desta forma o enriquecimento médio foi de $0,161 \%$. Gonzales et al. (1998) observaram proporção de ${ }^{15} \mathrm{~N}$ nas bactérias de $0,521 \%$ e teor de nitrogênio de $7,03 \%$. Valores próximos aos observados no presente trabalho. Por outro lado os valores de enriquecimento do ${ }^{15} \mathrm{~N}$ encontrados por Beckers et al (1995) foram mais elevados que o do 
presente trabalho, sendo de 0,243 e $0,194 \%$ para bactéria associadas a fração líquida e a fração sólida, respectivamente.

Tabela 3. Teor de nitrogênio, proteína bruta e abundância isotópica do pool de bactérias do rúmen de bovinos nelore recebendo diferente proporções de volumoso e concentrado $(\mathrm{V}: \mathrm{C})$

\begin{tabular}{lccc}
\hline Tratamento (V:C) & $\mathbf{N}(\% \mathbf{M S})$ & PB(\%MS) & ${ }^{15} \mathbf{N}(\%$ atm) \\
\hline $\mathbf{8 0 : 2 0}$ & 6,64 & 41,48 & 0,537 \\
$\mathbf{6 0 : 4 0}$ & 6,63 & 41,44 & 0,530 \\
$\mathbf{4 0 : 6 0}$ & 6,87 & 42,96 & 0,515 \\
Média & 6,71 & 41,96 & 0,527 \\
\hline
\end{tabular}

Os valores de $\mathrm{N}$ determinados nas bactérias isoladas no rúmen foi de $6,71 \% \mathrm{~N}$, valor aproximadamente $13,0 \%$ menor que o recomendado pelo NRC (1985). A composição química da bactéria varia com o tempo após a alimentação, nivel e freqüência do fornecimento da dieta e taxa e estágio de crescimento das bactérias. Segundo Clark et al. (1992) a composição química das bactérias isoladas no rúmen de vacas podem diferir de maneira significativa em função da dieta. Em sua revisão \%Nbact em 441 trabalhos variou de 4,8 a $10,9 \%$, estando os resultados no trabalho atual dentro deste intervalo.

A análise de variância indicou efeitos significativos para contaminação de nitrogênio (\%Nbact) e matéria seca de origem bacteriana (\%MSbact) nos resíduos após diferentes tempos de incubação ruminal $(P<0,05)$, não sendo observada diferenças entre as dietas $(P>0,05)$. De modo semelhante Dixon e Chanchai (2000) trabalhando com ovinos e fornecendo dietas apenas de feno de alfafa e aveia, ou com a adição de grãos de cevada, não observaram influência da dieta na proporção de nitrogênio bacteriano, porém houve efeito do tipo de alimento incubado. 
As análises das médias para \%MSbact e \%Nbact nos resíduos nos diferentes tempos de incubação são apresentadas nas tabelas 4 e 5 , respectivamente.

Tabela 4. Contaminação de matéria seca bacteriana (\%MSbact) nos resíduos após diversos tempos de incubação ruminal de alguns alimentos

\begin{tabular}{lcccccc}
\hline Tempo h & Milho & $\begin{array}{c}\text { Sorgo } \\
\end{array}$ & $\begin{array}{c}\text { Casca de } \\
\text { soja }\end{array}$ & $\begin{array}{c}\text { f. soja } \\
\text { \%MSbact }\end{array}$ & f. Algodão & $\begin{array}{c}\text { f. proteinoso } \\
\text { de milho }\end{array}$ \\
$\mathbf{3}$ & 1,8 & $1,5^{\mathrm{ab}}$ & $2,0^{\mathrm{a}}$ & $\begin{array}{c}\text { \%MS, } \\
\text { ab }\end{array}$ & 2,6 & $2,0^{\mathrm{a}}$ \\
$\mathbf{6}$ & 2,0 & $1,6^{\mathrm{ab}}$ & $1,4^{\mathrm{a}}$ & $2,2^{\mathrm{ab}}$ & 2,4 & $1,6^{\mathrm{a}}$ \\
$\mathbf{1 2}$ & 1,2 & $1,1^{\mathrm{b}}$ & $1,4^{\mathrm{a}}$ & $1,7^{\mathrm{b}}$ & 1,9 & $1,3^{\mathrm{a}}$ \\
$\mathbf{2 4}$ & 2,0 & $2,2^{\mathrm{ab}}$ & $3,8^{\mathrm{b}}$ & $2.9^{\mathrm{a}}$ & 2,7 & $2,2^{\mathrm{a}}$ \\
$\mathbf{4 8}$ & 2,1 & $2,7^{\mathrm{a}}$ & $3,6^{\mathrm{b}}$ & $2,1^{\mathrm{ab}}$ & 2,3 & $5,0^{\mathrm{b}}$ \\
$\mathbf{6 0}$ & - & & $3,5^{\mathrm{b}}$ & & - & $4,1^{\mathrm{b}}$ \\
EPM $^{2}$ & 0,3 & 0,3 & 0,4 & 0,4 & 0,4 & 0,5 \\
\hline
\end{tabular}

${ }^{1}$ Matéria seca bacteriana/matéria seca resíduo; ${ }^{2}$ Erro padrão da média

a, b, cMédias seguidas por letras sobrescritas distintas na mesma coluna são diferentes estatisticamente $(P<0,05)$.

Tabela 5. Contaminação nitrogênio bacteriana (\%N-bact/ $\mathrm{N}$-total) nos residuos após diversos tempos de incubação ruminal de alguns alimentos

\begin{tabular}{lcccrcc}
\hline Tempo $h$ & Milho & Sorgo & $\begin{array}{c}\text { Casca de } \\
\text { soja }\end{array}$ & f. soja & f. Algodão & $\begin{array}{c}\text { f. proteinoso } \\
\text { de milho }\end{array}$ \\
& & & & $\%$ Nbact & & \\
$\mathbf{3}$ & $4,7^{\mathrm{ab}}$ & $3,7^{\mathrm{a}}$ & $8,9^{\mathrm{bc}}$ & $1,8^{\mathrm{ab}}$ & $4,1^{\mathrm{a}}$ & $5,9^{\mathrm{c}}$ \\
$\mathbf{6}$ & $5,2^{\mathrm{ab}}$ & $2,6^{\mathrm{a}}$ & $6,5^{\mathrm{c}}$ & $1,4^{\mathrm{ab}}$ & $3,3^{\mathrm{a}}$ & $5,8^{\mathrm{c}}$ \\
$\mathbf{1 2}$ & $4,3^{\mathrm{b}}$ & $3,2^{\mathrm{a}}$ & $7,2^{\mathrm{c}}$ & $1,2^{\mathrm{a}}$ & $3,9^{\mathrm{a}}$ & $6,9^{\mathrm{c}}$ \\
$\mathbf{2 4}$ & $8,4^{\mathrm{c}}$ & $6,1^{\mathrm{b}}$ & $16,8^{\mathrm{a}}$ & $2,9^{\mathrm{b}}$ & $7,5^{\mathrm{b}}$ & $11,2^{\mathrm{b}}$ \\
$\mathbf{4 8}$ & $15,5^{\mathrm{d}}$ & $6,8^{\mathrm{b}}$ & $13,1^{\mathrm{ab}}$ & $4,7^{\mathrm{c}}$ & $8,9^{\mathrm{b}}$ & $21,0^{\mathrm{a}}$ \\
$\mathbf{6 0}$ & & & $11,4^{\mathrm{abc}}$ & & - & $15,6^{\mathrm{ab}}$ \\
EPM $^{2}$ & 1,1 & 0,6 & 2,2 & 0,6 & 0,6 & 2,1 \\
\hline
\end{tabular}

${ }^{1} \mathrm{~N}$-bacteriano/N-resíduo; ${ }^{2}$ Erro padrão da média

$a, b, c$ Médias seguidas por letras sobrescritas distintas na mesma coluna são diferentes estatisticamente $(P<0,05)$.

Alexandrov (1998) encontrou padrão de contaminação de nitrogênio bacteriano no resíduo de milho semelhante ao do presente trabalho, porém os valores encontrados para $24 \mathrm{~h}$ e $48 \mathrm{~h}$ de incubação ruminal foram de $18,0 \mathrm{e}$ $40,0 \%$ Nbact, respectivamente. Os valores encontrados pelos autores citados 
para \%MSbact no resíduo variou de 1,0 a 6,1 para os tempos de incubação de 2 e $48 \mathrm{~h}$, respectivamente.

Wanderley et al. (1993) usando a técnica de diluição isotópica com o isótopo estável de ${ }^{15} \mathrm{~N}$, porém trabalhando com alimentos enriquecidos através da fertilização com $\left({ }^{15} \mathrm{NH}_{4}\right)_{2} \mathrm{SO}_{4}$, observaram aumento linear na \%Nbact no resíduo de milho de 8 a $31 \%$ Nbact ( 3 e 48 h de incubação, respectivamente). Valores estes bem superiores ao do presente trabalho.

A contaminação bacteriana dos resíduos de milho foi maior nos tempos de 24 e 48 h $(8,4$ e 15,5 \%Nbact, $P<0,05)$. A \%MSbact não mostrou variações nos tempos de exposição ruminal, dessa forma a proporção de nitrogênio bacteriano aumentou em função do desaparecimento da proteína do alimento.

Os resíduos de sorgo apresentaram a maior \%Nbact com 24 e $48 \mathrm{~h}(6,8$ e $6,1 \%$ Nbact), e a \%MSbact foi diferente apenas entre os tempos de incubação de 12 e 48 h $(1,1 \times 2,7 \%$ MSbact, $P<0,05)$.

A casca de soja teve uma rápida contaminação microbiana com $3 \mathrm{~h}$ de exposição ruminal do alimento, tendo um pico com $24 \mathrm{~h}(16,8 \%)$, reduzindo-se nos tempos subseqüentes (48 e $60 \mathrm{~h}$ ). A \%MSbact nos resíduos apresentaram as mesmas tendências que $\mathrm{\%}$ Nbact.

Devido ao maior teor de proteína dos resíduos do farelo de soja, este apresentou menores proporções de Nbact em relação ao milho, sendo que a maior contaminação de nitrogênio de origem bacteriana no resíduo ocorreu apenas após $48 \mathrm{~h}$ de exposição $(4,7 \%, P<0,05)$, quando quase que praticamente toda a proteína da soja fora degradada. A \%MSbact do resíduo não apresentou variações ao longo do tempo, exceto entre 12 e $24 \mathrm{~h}(1,7 \times 2,9 \%$ MSbact, $\mathrm{P}<0,05)$.

Os valores de contaminação microbiana encontrados neste trabalho, especialmente nos resíduos do farelo de soja, foram inferiores aos descritos por Beckers et al. (1995), que observaram que a contaminação microbiana do farelo de soja e no farelo de trigo aumentou linearmente até 32 e $50 \%$ Nbact com o tempo de incubação de $48 \mathrm{~h}$, respectivamente. A farinha de carne e ossos 
manteve valores constantes de colonização $(5 \% \mathrm{Nbact})$ durante o período de incubação ruminal.

As contaminações encontradas nos resíduos alimentares do presente trabalho foram inferiores aos relatados por Wanderley et al. (1993), Beckers et al. (1995) e Alexandrov et al. (1998). Possivelmente esta diferença pode estar relacionada aos valores de $\mathrm{N}$ na composição bacteriana utilizados por aqueles autores, que adotaram $7,6 \% \mathrm{~N}(\mathrm{NRC}, 1985)$, enquanto que em nosso trabalho os teores de $\mathrm{N}$ utilizados foram os determinados após isolamento do pool bacteriano.

A contaminação do residuo de farelo de algodão com $\mathrm{N}$ bacteriano apresentou maiores valores $(P<0,05)$ para 24 e $48 \mathrm{~h}$ de incubação $(7,5$ e 8,9\% do $\mathrm{N}$-total), em relação aos outros tempos $(3,6,12)$. Entretanto não houve diferença significativa para os valores de \%MSbact no resíduo. A menor proporção de $\mathrm{N}$-bacteriano nos tempos iniciais é função da maior concentração de PB da amostra (Varvikko, 1986; Wanderley et al., 1993), aumentando ao longo do tempo com o desaparecimento desta. Provavelmente, em função da baixa degradabilidade dos constituintes da parede celular do farelo de algodão, diferente da fração protéica, não houve um correspondente aumento na MS microbiana.

O farelo proteinoso de milho apresentou um aumento significativo na $\% \mathrm{~N}$ microbiana após $24 \mathrm{~h}$ e $48 \mathrm{~h}$ de exposição ruminal $(11,2$ e $21,0 \%$ ), com diminuição após $60 \mathrm{~h}(15,6 \%)$. A \%MSbact no resíduo foi maior com o tempo de $48 \mathrm{~h}$ e $60 \mathrm{~h}$ (5,0 e 4,1\%). O aumento na contaminação do residuo com 24 e $48 \mathrm{~h}$ pode ser explicado pela alta solubilidade da proteína do produto aumentando a relação Nbact/Ntotal.

Nocek (1985), usando o DAPA como marcador mostrou que a \% Nbact no resíduo do farelo de soja apresentou um comportamento quadrático ao longo dos períodos de incubação, com uma rápida contaminação microbiana durante as primeiras 4 horas de incubação, e o pico com $12 \mathrm{~h}$ de incubação. De forma semelhante Wanderley et al. (1993) e Perez et al. (1996) observaram que a 
contaminação de bactéria nos resíduos dos alimentos estudados foi rápida entre 12 e $24 \mathrm{~h}$, com diminuição após 24 e $48 \mathrm{~h}$.

As observações apresentadas na tabela 5 estão de acordo com os autores supracitados, sendo que a maior contaminação microbiana para os resíduos de milho, casca de soja, sorgo e farelo de algodão foi maior entre 12 e $24 \mathrm{~h}$. Já os resíduos da soja e do farelo proteinoso do milho apresentaram elevada contaminação entre 12 até $48 \mathrm{~h}$.

Segundo Nocek (1985) e posteriormente Gonzales et al. (1998), as bactérias continuam a se aderir as partículas até que os sítios de adesão sejam saturados. Após o máximo de contaminação microbiana na casca de soja (24h) e no farelo proteinoso de milho (48h) houve redução na proporção de Nbact no resíduo, talvez pelo esgotamento de tais sítios, e aumento na concentração da proteina (proteína de baixa degradabilidade ruminal) do alimento em relação ao resíduo dos saquinhos. Segundo Church (1990) conforme digestão vai ocorrendo, a população bacteriana aderida se multiplica no substrato até que as células se soltam do residuo em busca de recolonizar novo substrato ou sair do rúmen. A redução na proporção de bactérias aderidas ao resíduo também poderia ser observado nos demais alimentos, desde que houvesse tempo adicional de incubação.

A contaminação bacteriana de cada alimento, quando expostos ao ambiente ruminal, ocorre de maneira diferente principalmente devido à composição química de cada ingrediente em particular, sendo que alimentos mais fibrosos e com menor teor de $\mathrm{N}$ tendem a apresentar maior \% Nbact (Varvikko et al., 1986; Wanderley et al. 1993; Perez et al., 1996; Alexandrov, 1998).

As alterações no $\mathrm{pH}$ do líquido ruminal apresentaram interação entre tratamento e tempo de avaliação $(P<0,05$, tabela 6$)$. Os resultados demostram rápida queda $(\mathrm{P}<0,05)$ com 1 e $2 \mathrm{~h}$ após a alimentação para o tratamento com $60 \%$ de concentrado $(P<0,05)$, em relação as outras duas proporções de 
concentrado. Esta rápida queda do $\mathrm{pH}$ se deve a degradação dos ingredientes altamente fermentecíveis do concentrado, como o milho.

Os tratamentos com 20 e $40 \%$ de concentrado apresentaram valores similares de $\mathrm{pH}(\mathrm{P}>0,05)$ durante todos os tempos de coleta de líquido ruminal após a alimentação. Apenas nas determinações feitas com 3 e $4 \mathrm{~h}$ os animais recebendo $40 \%$ de concentrado apresentaram pH intermediário $(P<0,05)$ as proporções de 20 e $60 \%$ de concentrado. As mensurações de $\mathrm{pH}$ ao longo dos diferentes períodos após a alimentação refletiram em médias menores para o tratamento $60 \%$ em relação a 20 e $40 \%(6,5 \times 6,7$ and 6,$8 ; P<0,05)$.

Tabela 6. Efeitos de diferentes proporções de concentrado no pH do líquido ruminal de bovinos Nelore

\section{Tempo}

\begin{tabular}{lcccccccc} 
Tratamento & $\mathbf{0}$ & $\mathbf{1}$ & $\mathbf{2}$ & $\mathbf{3}$ & $\mathbf{4}$ & $\mathbf{6}$ & $\mathbf{8}$ & Média \\
$\mathbf{8 0 : 2 0}$ & 6,9 & $6,9^{\mathrm{a}}$ & $6,8^{\mathrm{a}}$ & $6,8^{\mathrm{a}}$ & $6,7^{\mathrm{a}}$ & 6,6 & $6,9^{\mathrm{a}}$ & $6,8^{\mathrm{a}}$ \\
$\mathbf{6 0 : 4 0}$ & 6,9 & $6,9^{\mathrm{a}}$ & $6,8^{\mathrm{a}}$ & $6,6^{\mathrm{a}}$ & $6,6^{\mathrm{ab}}$ & 6,6 & $6,8^{\mathrm{a}}$ & $6,7^{\mathrm{a}}$ \\
$\mathbf{4 0 : 6 0}$ & 6,8 & $6,6^{\mathrm{b}}$ & $6,5^{\mathrm{b}}$ & $6,4^{\mathrm{b}}$ & $6,4^{\mathrm{b}}$ & 6,3 & $6,5^{\mathrm{b}}$ & $6,5^{\mathrm{b}}$ \\
Média & 6,9 & 6,8 & 6,7 & 6,6 & 6,6 & 6,7 & 6,7 & - \\
\hline
\end{tabular}

$\overline{a, b}$ medias na mesma coluna seguidas por letras distintas são significativamente diferentes $(P<0,05)$

Detmann et al. (2001) não encontraram diferenças entre as fontes de energia, milho (amido) ou farelo de trigo (fibra de alta digestão), e nem das quantidades de suplementos ( 1 ou $2 \mathrm{~kg}$ por cabeça por dia) sobre os valores de $\mathrm{pH}$ ruminal. $\mathrm{O}$ único efeito significativo foi o horário de coleta, onde se observou valor minimo de 6,32, ocorrendo 3,2 horas após a suplementação. Observação esta condizentes com os resultados da tabela 6, especialmente para os tratamentos com 60 e $40 \%$ de concentrado.

Já para o tratamento com $20 \%$ de concentrado o menor valor ocorreu após $6 \mathrm{~h}$ da alimentação, indicando que para este tratamento o que afetou a redução do $\mathrm{pH}$ foi a fermentação da forragem que a do concentrado. De forma semelhante, Soriano et al. (2000) sugeriram que as reduções no $\mathrm{pH}$ do líquido 
ruminal foram afetadas mais pela fermentação da forragem que pela fermentação do amido contido nos suplementos.

Sabe-se que o pH é um dos fatores de maior importância na eficiência de crescimento dos microrganismos e que pode afetar a adesão destes as partículas dos alimentos (Church, 1990). No presente trabalho, pode-se observar que os valores de $\mathrm{pH}$, mesmo para a maior proporção de concentrado na dieta esteve acima do valor mínimo $(6,2)$ para a ótima função ruminal (Dixon \& Stockdale, 1999). Pode-se especular, em função da ausência de efeitos de tratamento para \%Msbact e \%Nbact (Tabelas 4 e 5 , respectivamente) nos resíduos, não houve nenhum efeito negativo quanto a capacidade de adesão microbiana (tabela 4 e 5), podendo estender estas suposições e inferir que a proliferação bacteriana também não tenha sido afetada.

Na tabela 7 são apresentados as concentrações totais de AGV's no fluido ruminal, bem como as proporções individuais de cada AGV. As concentrações totais dos AGV's foi maior $(\mathrm{P}<0,05)$ para o tratamento com $60 \%$ de após $2 \mathrm{~h}$ da alimentação em relação ao tratamento com $20 \%$. No entanto apesar de não ter sido observadas diferenças significativas $(P>0,05)$ nos outros tempos após a alimentação, a concentração dos AGV's sempre apresentaram numericamente maiores valores em relação aos outros tratamentos. Este tendência refletiu na média final em concentrações superiores $(P<0,05)$ para o tratamento com $60 \%$ em relação aos tratamentos com 20 e $40 \%$ de concentrado $(91,4 \times 71,7$ e 79,7 $\mathrm{mM} / \mathrm{ml}$, respectivamente).

Os menores valores observados para o $\mathrm{pH}$ do liquido ruminal dos animais quando consumiram $60 \%$ de concentrado, muito provavelmente está diretamente relacionada com as maiores produções de ácidos graxos voláteis, além do provável aumento na produção de lactato (Dixon \& Stockdale 1999), que no presente trabalho não foi avaliado. 
Tabela 9. Efeitos de diferentes proporções de concentrado, na produção de ácidos graxos voláteis $(\mathrm{mM} / \mathrm{ml})$, nas proporções molares $(\% \mathrm{mM})$ de ácido acético, ácido propiónico, ácido butírico e na relação do ácido acético:propiónico no líquido ruminal d e bovinos Nelore

\section{Tempo}

$\begin{array}{lllllllll}\text { Tratamento } & 0 & 1 & 2 & 3 & 4 & 6 & 8 & \text { Media }\end{array}$

AGV totais $(\mathrm{mM} / \mathrm{ml})$

$\begin{array}{llllllllc}\mathbf{8 0 : 2 0} & 66,1 & 79,2 & 75,6^{\mathrm{a}} & 76,3 & 80,3 & 70,2 & 53,7 & 71,7^{\mathrm{a}} \\ \mathbf{6 0 : 4 0} & 69,0 & 83,5 & 87,2^{\mathrm{ab}} & 87,8 & 85,7 & 75,3 & 62,3 & 79,7^{\mathrm{a}} \\ \mathbf{4 0 : 6 0} & 75,6 & 92,1 & 106,0^{\mathrm{b}} & 96,2 & 95,1 & 89,2 & 78,9 & 91,4^{\mathrm{b}} \\ \text { Média } & 70,4 & 84,9 & 89,6 & 86,8 & 87,0 & 78,2 & 65,0 & -\end{array}$

Ácido acético (\%mM)

80:20

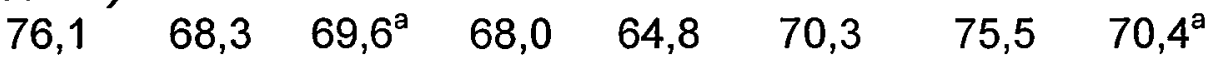

$60: 40$

$79,4 \quad 68,4 \quad 65,0^{\text {ab }} \quad 65,9$

$67,0 \quad 70,5$

$75,7 \quad 70,2^{\mathrm{a}}$

40:60

75,5

$62,8 \quad 62,3^{\mathrm{b}} \quad 63,5$

$64,3 \quad 67,5$

$72,4 \quad 66,9^{\mathrm{b}}$

Média

$77,0 \quad 66,5$

$65,6 \quad 65,8$

$65,4 \quad 69,5$

74,5

Ácido propiónico (\%mM)

\begin{tabular}{|c|c|c|c|c|c|c|c|c|}
\hline $80: 20$ & 15,3 & 20,7 & $19,9^{\mathrm{a}}$ & 21,7 & 22,9 & 18,3 & 16,0 & $19,3^{a}$ \\
\hline $60: 40$ & 13,1 & 21,3 & $22,8^{\mathrm{ab}}$ & 21,7 & 20,9 & 18,3 & 16,2 & $19,2^{\mathrm{a}}$ \\
\hline $40: 60$ & 14,4 & 24,9 & $24,4^{\mathrm{b}}$ & 23,3 & 21,8 & 20,7 & 17,9 & $21,0^{b}$ \\
\hline Média & 14,3 & 22,3 & 22,4 & 22,2 & 21,9 & 19,1 & 16,7 & \\
\hline \multicolumn{2}{|c|}{ Ácido butírico (\%mM) } & 10,9 & 10,5 & 10,3 & 12,5 & 11,3 & 8,4 & $10,4^{a}$ \\
\hline $60: 40$ & 7,5 & 10,2 & 13,5 & 12,3 & 12,4 & 11,2 & 8,2 & $10,8^{a b}$ \\
\hline 40:60 & 10,3 & 12,4 & 13,5 & 13,4 & 17,8 & 11,8 & 9,9 & $12,8^{b}$ \\
\hline Média & 8,8 & 11,2 & 12,5 & 12,0 & 14,2 & 11,4 & 8,8 & - \\
\hline \multicolumn{9}{|c|}{ Acético:propiónico } \\
\hline $60: 40$ & $6,3^{a}$ & 3,2 & 2,9 & 3,1 & 3,3 & 3,9 & 4,7 & $3,9^{a}$ \\
\hline $40: 60$ & $5,3 b$ & 2,6 & 2,6 & 2,8 & 3,0 & 3,3 & 4,1 & $3,4^{\mathrm{b}}$ \\
\hline Média & 5,6 & 3,1 & 3,0 & 3,0 & 3,0 & 3,7 & 4,5 & \\
\hline
\end{tabular}

${ }^{a, b}$ medias na mesma coluna seguidas por letras distintas são significativamente diferentes $(P<0,05)$ 
De maneira semelhante às concentrações totais de AGV's, as proporções individuais de cada ácido graxo, exceto para o ácido butírico, ao longo dos diferentes períodos pós alimentação. As proporção molar de ácido acético foi menor para o tratamento $60 \%$ em relação ao tratamento $20 \%(62,3 \times 69,6 \%$, $P<0,05$ ), enquanto o tratamento $40 \%$ apresentou proporções intermediárias $(65,0 \%)$. A média geral ao longo dos tempos de coleta indicou menores proporções de ácido acético para o tratamento $60 \%$ em relação aos com 20 e $40 \%$ de concentrado ( $66,9 \times 70,2$ e $70,4 \%, P<0,05)$.

A redução da proporção de ácido acético em relação ao aumento ao tratamento com maior proporção de concentrado, esta diretamente relacionado com o aumento de proporção de ácido propiónico, onde o tratamento $60 \%$ apresentou maiores proporções que o tratamento com $20 \%$ de concentrado $(24,4 \times 19,9 \%, P<0,05)$. Na média geral as maiores proporções foram observados para o tratamento 60 em relação a 20 e $40 \%(19,3,19,2 \times 21,0 \%$, $P<0,05)$.

Quanto a proporção molar de ácido butírico só foi possivel observar efeitos significativos para média geral dos tempos de coleta de líquido ruminal, onde o fornecimento de $60 \%$ de concentrado promoveu aumento em relação ao tratamento $20 \%(12,8 \times 10,4, P<0,05)$, e os valores para os animais recebendo $40 \%$ de concentrado foram intermediários. Grigsby et al. (1997) observaram aumento nos níveis de ácido butírico, com o incremento da dose de amido em substituição à fibra da casca de soja, em suplementos fornecidos para bovinos alimentados com feno de baixo valor nutritivo. Elizalde et al. (1999) observou incrementos lineares nas concentrações de ácido butírico com aumento no fornecimento de milho moido para animais consumindo alfafa como volumoso.

Heldt et al. (1999a) e Heldt et al. (1999b) observaram maiores proporções de ácido propiónico e ácido butírico e diminuição de ácido acético com a suplementação de bovinos com diferentes fontes de carboidratos. Os autores mencionam sobre uma relação inversa entre a produção de acetato e butirato, que seria razoável em função de ambos os ácidos graxos serem derivados da 
acetilCOA. Satter \& Esdale (1968) referem-se que o aumento de lactato no rúmen e seu metabolismo por outras bactérias ruminais, estaria associado em parte ao aumento do propionato e do butirato.

Em algumas condições as dietas com concentrados podem aumentar a população de algumas espécies de protozoários, que podem estar associados a ao aumento da produção de butirato (Veira, 1986, Church, 1990).

A relação acetado propionato apresentou diferenças significativas apenas para o tempo 0 , onde o tratamento $60 \%$ apresentou a menor relação $(P<0,05)$ que os animais recebendo 20 e $40 \%$ de concentrado. Apesar da ausência de diferenças estatísticas entre os tratamentos no demais tempos de colheita de líquido ruminal, os animais recebendo $60 \%$ de concentrado apresentaram uma diferença numérica com menores valores para a relação acetato:propionato. Estas diferenças numéricas, por fim refletiram em menores valore médios de todos os tempos para o tratamento $60 \%$ quando comparado com 20 e $40 \%$ (3,4 $X 3,8$ e $3,9, P<0,05)$. Isto se deve basicamente pelo aumento na proporção de ácido propiónico e diminuição do ácido acético em função da fermentação de carboidratos não estruturais.

A alimentação com concentrado rico em grãos reduz a proporção molar de ácido acético e aumenta a proporção molar de acido propiônico no fluido ruminal de animais (Church 1990, Van Soest, 1994), reduzindo a relação acetato:propionato (Church, 1990).

As concentrações de nitrogênio amoniacal $\left(\mathrm{N}-\mathrm{NH}_{3}\right)$ no líquido ruminal ao longo do tempo após alimentação são apresentados na Tabela 8. A análise de variância indicou efeito altamente significativo da interação entre tratamento e tempo após alimentação $(P=0,0001)$. No entanto as diferenças entre tratamentos foram detectadas apenas com 2 horas após a alimentação, onde as concentrações de $\mathrm{N}-\mathrm{NH}_{3}$ foram maiores para os tratamentos 20 e $40 \%$ em relação ao $60 \%$ de concentrado $(18,2,19,7 \times 12,9 \mathrm{mg} / \mathrm{L}, \mathrm{P}<0,05)$. A média geral manteve as mesmas tendências, onde os tratamentos 20 e $40 \%$ 
apresentaram concentrações de $\mathrm{N}-\mathrm{NH}_{3}$ superiores ao $60 \%(11,3$ e 11,3 $\times 9,0$ $\mathrm{mg} / \mathrm{L}, \mathrm{P}<0,05)$.

Tabela 8. Efeitos de diferentes proporções de concentrado na concentração de nitrogênio amoniacal ( $\mathrm{N}-\mathrm{NH}_{3} \mathrm{mg} / \mathrm{L}$ ) no líquido ruminal de bovinos Nelore

\begin{tabular}{lcccccccc}
\hline & \multicolumn{8}{c}{ Tempo } \\
Tratamento & $\mathbf{0}$ & $\mathbf{1}$ & $\mathbf{2}$ & $\mathbf{3}$ & $\mathbf{4}$ & $\mathbf{6}$ & $\mathbf{8}$ & Media \\
& & \multicolumn{7}{c}{$\mathbf{m g} / \mathbf{L}$} \\
$\mathbf{8 0 : 2 0}$ & 6,3 & 17,4 & $18,2^{\mathrm{a}}$ & 17,0 & 14,2 & 4,2 & 2,1 & $11,3^{\mathrm{a}}$ \\
$\mathbf{6 0 : 4 0}$ & 6,3 & 14,3 & $19,7^{\mathrm{a}}$ & 17,3 & 14,7 & 4,0 & 2,5 & $11,3^{\mathrm{a}}$ \\
$\mathbf{4 0 : 6 0}$ & 5,7 & 12,1 & $12,9^{\mathrm{b}}$ & 12,7 & 11,8 & 5,3 & 2,6 & $9,0^{\mathrm{b}}$ \\
Media & 6,1 & 14,5 & 16,9 & 15,7 & 13,6 & 4,5 & 2,4 & - \\
\hline
\end{tabular}

${ }^{a, b}$ medias na mesma coluna seguidas por letras distintas são significativamente diferentes $(P<0,05)$

O pico de produção de amônia ocorreu após 2 horas do fornecimento dos alimentos, mantendo-se relativamente elevadas até $4 \mathrm{~h}$ após a alimentação dos animais. Segundo Church (1990) o pico em dietas com uréia se dá em torno de 1-2 h, e dietas com grande quantidade de proteína vegetal o pico se dá entre 3 a $5 \mathrm{~h}$. As concentrações de amônia ao longo do tempo manteve-se acima da concentração mínima (2 a $5 \mathrm{mg} / \mathrm{L}$ ) propostos por Satter \& Roffler (1979) para ótima atividade microbiana.

Aparentemente, os tratamentos com 20 e $40 \%$ de concentrado apresentaram maiores concentrações de amônia, em função da menor eficiência de utilização da amônia pelas bactérias ruminais. A concentração de nitrogênio amoniacal no rúmen, depende da degradabilidade da proteína da fonte protéica utilizada, e do equilíbrio entre sua produção e utilização pelos microrganismos.

Para otimização da síntese de proteína microbiana é necessária a sincronização entre fermentação dos carboidratos com a degradação das proteína (Firkins, 1996), desta forma a concentração de $\mathrm{N}-\mathrm{NH}_{3}$ no rúmen 
depende basicamente da degradabilidade da proteína, disponibilidade de carboidratos (Satter \& Roffler, 1979, Nocek \& Russell, 1988; Church, 1990, Russel et al., 1992; Firkins, 1996) e do equilíbrio entre sua produção e utilização pelos microrganismos.

Muito provavelmente a menor eficiência no uso do nitrogênio amoniacal ocorreu devido a possivel deficiência de energia (carboidratos) na dieta. Os microrganismos dependem da energia oriunda da fermentação dos carboidratos para a biosíntese de proteína microbiana, caso contrário os peptídeos e aminoácidos passam a ser utilizados como fontes de energia, ocorrendo acúmulo de amônia no meio (Russell et al., 1992).

Um efeito marcante do $\mathrm{pH}$ na fermentação ruminal seria sobre as perdas de nitrogênio amoniacal, que são mais elevadas quando há condição de acidez ruminal, ocasionadas pela redução na taxa de degradação da fibra (Hoover 1986). Isto no entanto não é o caso em relação as observações feitas acima para os tratamentos 20 e $40 \%$, pois o $\mathrm{pH}$ esteve sempre acima de 6,5 nestes tratamentos.

\subsection{Conclusões}

O aumento na proporção de nitrogênio bacteriano nos resíduos de 24 e 48 $\mathrm{h}$ pode ser explicado pela perda de substrato (proteína), que diminuiu a diluição do ${ }^{15} \mathrm{~N}$ microbiano, desta forma aumentando a $\%$ Nitrogênio bacteriano no resíduo. A contaminação do resíduo de incubação ruminal aumentou, de forma geral, com o tempo de exposição ruminal, porém a intensidade com que ocorreu variou em função da estrutura física e composição química dos ingredientes avaliados. A ausência de efeitos de tratamentos para determinação da contaminação microbiana pode ser explicada pelas pequenas alterações em relação ao ambiente ruminal, sendo que as mais significativas ocorreram nas dietas com $60 \%$ de concentrado, com menores valores de $\mathrm{pH}$, porém dentro da amplitude aceitável para a ótima atividade ruminal. Este menor ph ocorreu em 
decorrência da maior produção de ácidos graxos voláteis. Nesta variável destaca-se a alteração nas proporções individuais, onde houve diminuição relativa de ácido acético, e aumento de ácido propiónico e butírico no tratamento com $60 \%$ de concentrado. Os maiores valores de amônia encontrados para os tratamentos com 20 e $40 \%$ de concentrado indicam uma baixa eficiência de uso do nitrogênio pelos microrganismos ruminais, que provavelmente ocorreu devido a baixa disponibilidade de carboidratos. 


\section{EFEITO DA DIFERENTES PROPORÇÕES DE CONCENTRADO NA NA CINÉTICA DE DEGRADAÇÃO DOS ALIMENTOS CORRIGIDOS OU NÃO PARA CONTAMINAÇÃO MICROBIANA.}

\section{Resumo}

Foram utilizados seis bovinos Nelore canulados no rúmen dispostos em quadrado latino duplo $3 \times 3$ com repetição, com o objetivo de avaliar os efeitos de diferentes proporções de concentrado (20, 40 e 60\%) na dieta sobre a degradação de diferentes fontes alimentares com ou sem correção para contaminação microbiana. Os alimentos testados foram farelo de soja, farelo de algodão, milho, sorgo, casca de soja e farelo de glúten de milho. As incubações ruminais dos saquinhos para as avaliações das degradabilidade da MS e PB foram feitas às $0,3,6,12,24,48 \mathrm{~h}$, e concomitantemente, foram realizadas infusões ruminais de ${ }^{15} \mathrm{~N}$ para determinação da contaminação microbiana através da diluição isotópica nos tempos de incubação ruminal. A casca de soja apresentou valores de degradabilidade efetiva (DE) da PB corrigida para contaminação microbiana maiores $(P<0,10)$ para todas as taxas de passagem que as estimativas feitas sem correção. O milho teve efeito maior $(P<0,05) \mathrm{DE}$ para o tratamento com $60 \%$ de concentrado para $M S(2,0,5,0$ e $8,0 \% / h)$, e para PB $(k p=8,0 \% / h)$. As DE's da PB do farelo proteinoso de milho com $k p$ de 2, 5 e $8 \% / h$ apresentaram efeito significativos $(P<0,10)$ para correção da contaminação microbiana do resíduo. O farelo de soja apresentou efeito de tratamento $(P<0,10)$ para a DE da MS com $k p$ de 5,0 e $8,0 \% / h$ e da PB com $k p$ de $8,0 \% / h$, sendo menor os valores $(P<0,10)$ para o tratamento com $60 \%$ de concentrado. A correção do resíduo do farelo de algodão para contaminação 
microbiano apresentou efeito significativo $(P<0,10)$ na $D E$ da MS para todas as taxas de passagem e na DE da PB apenas para $k p$ de $2 \% / h$. Os maiores valores $(P<0,10)$ para digestibilidade intestinal da $P N D R$ foram observados para casca de soja $(81,7 \%)$, milho $(87,1 \%)$ e sorgo $(82,4 \%)$, enquanto que os menores foram os do farelo proteinoso de milho $(57,6 \%)$ e do farelo de soja $(53,4 \%, P<0,10)$, e o farelo de algodão $(70,9 \%)$ valor intermediário. A digestibilidade total da proteína dos alimentos diferiram entre si $(P<0,10)$, sendo que apenas o milho e o farelo proteinoso de milho apresentaram digestibilidade semelhantes $(P>0,10)$.

Effects of different concentrate ratios on rumen degradation kinetics of feedstuffs corrected or not for microbial contamination

\section{Summary}

Six rumen cannulated Nelore steer were used in replicated latin square design $(3 \times 3)$, with the objective of analyze the effects of different ratios of concentrate $(20,40,60 \%)$ on in situ ruminal degradation kinetics corrected or not for the microbial contamination or. The tested feed were soy bean hulls, corn, sorghum grain, soy bean meal, cottonseed meal and corn gluten feed. The soy bean hulls had higher rumen effective degradability when corrected for microbial contamination $(P<0,10)$ for all estimated passages rates. The corn had higher rumen dry matter effective degradability $(E D, P<0,10)$ with animals on $60 \%$ concentrated treatment, and the crude protein $(C P)$ were higher $(P<0,010)$ only with passage rates of $5 \% / h$. The $\mathrm{CP}$ effective degradability of the corn gluten feed showed a significant difference when corrected for microbial nitrogen contamination $(P<0,10)$. The dry matter $E D$ of soy bean meal of animal on $60 \%$ concentrate diet showed lower values with passage rates of 5 and $8 \% / h$. The microbial contamination correction of the cottonseed meal residues had a significant effect $(P<0,10)$ of dry matter ED with all the passage rates, and for 
the CP were significant only with estimates of $2 \% / \mathrm{h}$. The in vitro intestinal digestibilities rumen undegradable protein (RUP) were higher $(P<0,10)$ to soy bean hulls $(81,7 \%)$, corn $(87,1 \%)$ and sorghum $(82,4 \%)$ than corn gluten meal $(57,6)$. The total digestibility estimate (rumen and intestine) were different $(P<10)$ and only corn and corn gluten meal ha similar values.

\subsection{Introdução}

A digestão em ruminantes é um sistema complexo, envolvendo a atividade simbiótica de microrganismos com o hospedeiro. A eficiência dessa simbiose é altamente susceptível a alterações do meio. Os sistemas de avaliação e formulação de dietas têm aprimorado os modelos usando de informações sobre cinética da degradação das diferentes frações dos alimentos, e suas implicações nos padrões de fermentação, síntese de proteína microbiana e sobre a disponibilidade e qualidade dos compostos a serem absorvidos.

Os trabalhos realizados nos últimos anos têm demonstrado que a taxa e a quantidade de nutrientes degradados no rúmen podem ter grande impacto nos produtos finais da fermentação ruminal, e consequentemente no desempenho animal. Com isto, nos últimos anos, nutricionistas vêm buscando balancear e sincronizar a degradação das frações nitrogenadas e de carboidratos. Se a taxa de degradação de proteína exceder a de carboidratos, grande quantidade de nitrogênio pode ser perdida na forma de amônia. Por outro lado, se a degradação de carboidratos for maior que a de proteína, a síntese microbiana vai ser menor (Russell et al., 1992; Van Kessel e Russell, 1996). A extensão com que os nutrientes são degradados é determinada estreitamente pela competição entre taxa de degradação e de passagem, sendo que o conhecimento de ambas é necessário para estimar a quantidade de energia e proteina disponíveis no rúmen (Russell et al., 1992). 
Sistemas de formulação de ração requerem informações, não só das exigências do animal, mas também das frações realmente disponiveis dos nutrientes de cada alimento. As metodologias adotadas pelos principais modelos (AFRC, 1995; INRA, 1989; NRC 1984, 2000, 2001) para determinação da cinética de degradação da proteína no rúmen têm sido os métodos in situ com sacolas de nylon e os in vitro.

O método in situ, apesar das grandes variações entre laboratórios (Broderick \& Cochran, 2000) é o mais utilizado. O modelo matemático exponencial proposto por Ørskov \& McDonald (1979) é comumente usado para descrever a cinética de degradação ruminal dos alimentos. As constantes matemáticas identificadas no modelo podem ser interpretadas como porção solúvel (a) e potencialmente degradável (b), e a taxa de degradação desta fração (c). Para estimar a degradabilidade efetiva pelo modelo usa-se a taxa de passagem do alimento, podendo usar um valor determinado experimentalmente ou um pré-estabelecido.

O NRC (2001) para gado leiteiro adotou o método in situ para identificar e estimar as três frações nitrogenadas, definidas como $A, B$ e $C$, e a taxa de degradação $\left(k_{d}\right)$ da fração $B$. Onde A representa o NNP, a proteína rapidamente solubilizada e a proteína presente no alimento em partículas menores que a porosidade dos sacos de nylon/poliester usados nos ensaios. A fração $\mathrm{B}$ corresponde à proteína potencialmente degradável, cuja extensão de degradação depende da taxa de degradação $\left(K_{d}\right)$ e da taxa de passagem $\left(K_{p}\right)$. $A$ fração $C$ é definida como sendo a fração de proteína indisponivel para degradação ruminal.

Valores de degradação obtidos pela metodologia in situ apresentam grandes variações entre laboratórios. É importante uma padronização da metodologia com relação às principais fontes de erros, como tamanho de partícula, tamanho do saquinho e dos poros, e material usado na confecção dos sacos (Vanzant et al. 1998; Broderick \& Cochran, 2000). 
Segundo revisão feita por Vanzant et al. (1998) e mais recentemente por Broderick e Cochran (2000), uma outra importante fonte de erro da técnica in situ é a contaminação microbiana do resíduo, podendo levar a subestimativas da degradabilidade da MS e principalmente da proteína bruta.

Os objetivos do presente trabalho foram avaliar, os efeitos das diferentes proporções de concentrado na cinética de degradação de diversos alimentos usando a metodologia in situ, com ou sem correção para contaminação microbiana dos resíduos, e estimar a digestibilidade intestinal in vitro da PB não degradada no rúmen.

\subsection{Material e Métodos}

\subsubsection{Animais e dieta experimental}

O trabalho foi realizado na Estação Experimental Central do Instituto de Zootecnia, localizado no municipio de Nova Odessa, SP. Foram utilizados seis bovinos Nelore providos de fistula ruminal com peso inicial de aproximadamente $380 \mathrm{~kg}$, alojados em gaiolas de metabolismo, em um delineamento do tipo Quadrado Latino $3 \times 3$, com duas repetições por tratamento em cada período. No primeiro período experimental os 6 animais foram distribuídos por sorteio para os diferentes tratamentos, sendo 2 animais para cada tratamento, e nos períodos subsequentes os animais mudavam de tratamento.

Os tratamentos testados foram: $80: 20-80 \%$ de volumoso e $20 \%$ de concentrado, 60:40- $60 \%$ de volumoso e $40 \%$ de concentrado ou $40: 60-40 \%$ de volumoso e $60 \%$ de concentrado. $O$ volumoso utilizado foi a silagem de milho, e no concentrado utilizou-se milho triturado, farelo de soja, farelo de algodão, casca de soja, sorgo em grão moído e farelo proteinoso de milho. Os alimentos bem como as proporções de concentrado utilizadas foram escolhidas pois são tipicamente utilizadas em confinamentos no Brasil para bovinos Nelore. 
$\mathrm{Na}$ Tabela 1 são apresentadas as composições químicas de cada ingrediente utilizados na formulação das diferentes dietas (Tabela 2), balanceadas em função dos tratamentos.

Tabela 1. Composição química dos ingredientes

\begin{tabular}{lcccccccc}
\hline Alimento & MS & PB & EE & FDN & FDA & $\begin{array}{c}\text { PBFDA } \\
\text { (\%PB) }\end{array}$ & Lig & MM \\
\hline Milho & 87,5 & 10,4 & 4,3 & 25,6 & 5,1 & 6,8 & 1,1 & 1,1 \\
Casca de soja & 89,7 & 13,6 & 3,1 & 69,0 & 51,7 & 3,7 & 2,2 & 4,6 \\
Sorgo & 84,4 & 10,1 & 2,5 & 32,6 & 7,3 & 5,6 & 4,5 & 1,6 \\
F. p. Milho & 90,4 & 25,7 & 3,0 & 44,6 & 10,9 & 10,3 & 1,2 & 5,0 \\
F. soja & 90,3 & 54,5 & 0,7 & 16,6 & 11,6 & 4,3 & 0,8 & 6,5 \\
F. algodão & 92,2 & 37,0 & 1,1 & 51,5 & 33,7 & 9,3 & 14,8 & 5,1 \\
Silagem de milho & 29,1 & 8,3 & 1,6 & 61,2 & 32,9 & - & 2,7 & 5,3 \\
\hline
\end{tabular}

MS- Matéria seca; PB-Proteina bruta, EE- Extrato etéreo. FDN- Fibra em detergente neutro, FDA- Fibra em detergente ácido, PBFDA-Proteina bruta ligada ao FDA (\% da PB) Lig.- lignina, MM- matéria mineral, EB- Energia bruta.

Tabela 2. Proporções dos ingredientes e composição química dos concentrados

\begin{tabular}{|c|c|c|c|}
\hline Ingredientes (\%MS) & $80: 20$ & $60: 40$ & $40: 60$ \\
\hline Silagem de milho & 79,6 & 58,5 & 39,4 \\
\hline Farelo de Soja & 3,5 & 3,6 & 5,4 \\
\hline Farelo de grão de milho & 4,2 & 9,4 & 13,5 \\
\hline f. algodão & 2,2 & 3,6 & 4,1 \\
\hline Sorgo em grãos & 2,8 & 8,0 & 13,5 \\
\hline F. proteinoso de milho & 2,1 & 4,7 & 6,1 \\
\hline Casca de soja & 2,8 & 9,8 & 16,2 \\
\hline Uréia & 1,3 & 1,0 & 0,5 \\
\hline Mistura Mineral* & 1,5 & 1,4 & 1,4 \\
\hline \multicolumn{4}{|c|}{ Composição química das dietas } \\
\hline MS (\%MO) & 40,7 & 52,8 & 63,7 \\
\hline PB (\%MS) & 15,6 & 17,8 & 16,8 \\
\hline EE (\%MS) & 2,2 & 2,2 & 2,3 \\
\hline FDN (\%MS) & 50,7 & 47,4 & 44,8 \\
\hline FDA (\%MS) & 30,5 & 27,6 & 25,8 \\
\hline MM (\%MS) & 6,2 & 6,0 & 5,4 \\
\hline \multicolumn{4}{|l|}{ Consumo da ração } \\
\hline $\begin{array}{l}\text { KgMS/dia } \\
\text { g/PV }^{0,75}\end{array}$ & $\begin{array}{c}7,9 \\
84,6\end{array}$ & $\begin{array}{c}9,1 \\
97,6\end{array}$ & $\begin{array}{c}9,0 \\
96,5\end{array}$ \\
\hline
\end{tabular}


As dietas foram formuladas com base no "Cornell Net Carbohydrate and Protein System" (CNCPS 4.2; Fox et al., 2000), com a otimização da função ruminal. A quantidade de alimento fornecido inicialmente foi de $100 \mathrm{~g}$ de MS / kg PV ${ }^{0,75}$, sendo realizados ajustes quando necessário, de modo que não ocorressem sobras. A ração foi fornecida em duas refeições diárias as 8:00 e 15:00 horas.

\subsubsection{Degradabilidade ruminal}

A incubação ruminal dos saquinhos (Orskov \& McDonald, 1979) para determinação da degradabilidade ruminal da MS e PB começou no $10^{\circ}$ dia após o início da adaptação dos animais às dietas.

Os saquinhos $(12 \times 21 \mathrm{~cm})$ com porosidade de $50 \mu$ foram preenchidos com aproximadamente 12 gramas de amostras das diferentes fontes alimentares, tendo-se uma relação de tamanho da amostra por área do saquinho de $23,8 \mathrm{mg} / \mathrm{cm}^{2}$, próximo ao intervalo de 10 a $20 \mathrm{mg} \mathrm{cm}$ proposto por Nocek (1988). Os saquinhos continham 2 bolas de gude para manter os sacos submersos no rúmen, e uma argola de metal para serem fixados ao mosquetão que estava amarrado a corda de nylon de $50 \mathrm{~cm}$ de comprimento. Os saquinhos eram posicionados e submersos no rúmen em triplicata por $0,3,6,12,24,48 \mathrm{~h}$, sendo que o farelo proteinoso de milho e a casca de soja tiveram um período extra referentes a $60 \mathrm{~h}$ de incubação ruminal. As incubações foram feitas imediatamente após fornecimento da ração aos animais. As incubações e retirada dos saquinhos foram feitas seguindo os esquema do quadro 1:

Após a retirada dos sacos, estes foram lavados em lavadora automática por cerca de 20 minutos com 4 enxágües no modo para tecidos delicados, para que a água fluisse incolor. Após lavagem os mesmos foram secos em estufa com ventilação de ar forçada a $60^{\circ} \mathrm{C}$ por 72 horas, sendo em seguida pesados. 


\begin{tabular}{|l|l|}
\hline Dia & Atividade: \\
\hline 1 a 7 & Adaptação as dietas experimentais \\
\hline 8 a 13 & Dosagem de $360 \mathrm{mg}{ }^{15} \mathrm{~N}$. \\
\hline 10 & Incubação dos saquinhos $48 \mathrm{~h}$ e $60 \mathrm{~h}$ \\
\hline 11 & Incubação dos saquinhos $24 \mathrm{~h}$ \\
\hline 12 & $\begin{array}{l}\text { Retirada dos saquinhos } 48 \text { e } 24 \mathrm{~h} \text {, incubação e retirada } \\
\text { dos saquinhos de } 12 \mathrm{~h}, \text { e retirada dos saquinhos de } 60 \mathrm{~h} .\end{array}$ \\
\hline 13 & Incubação e retirada dos saquinhos $3 \mathrm{~h}$ e $6 \mathrm{~h}$. \\
\hline
\end{tabular}

Quadro 1- Esquematização das atividades de dosagem de $15 \mathrm{~N} \mathrm{e}$ incubação dos saquinhos de nylon no rúmen

Os cálculos foram feitos utilizando-se a seguinte formula:

$$
\text { DgMS\% }=\frac{100 \times(1-\text { PSPI-PSV })}{\text { (PSAI-PSV) }}
$$

onde: $\mathrm{DgMS} \%$ é a degradabilidade da matéria seca em porcentagem, PSPI é o peso do saco pós-incubação ruminal, PSAl é o peso do saco antes da incubação ruminal, e PSV é o peso do saco vazio.

A degradabilidade da PB foi calculada através da mesma fórmula, usando valores de PB no lugar dos valores de MS. Os dados de degradabilidade (MS e PB) foram ajustados ao modelo matemático exponencial proposto por Orskov e Mcdonald (1979):

$$
P=a+b\left(1-e^{-c t}\right)
$$

Onde, "P" é a quantidade de nutriente degradada no tempo "t", "a" é o intercepto da curva no tempo zero, "b" a fração potencialmente degradável no rúmen, e "c" é a taxa de degradação $(k d)$ por hora da fração "b". A letra "e" é o log natural de -ct.

A degradabilidade efetiva (DE) foi calculada segundo a equação:

$$
D E=\frac{a+(b \times c)}{(c+k)}
$$

onde, " $k$ " representa a taxa de passagem do alimento pelo rúmen (\% por hora), de acordo com Orskov et al. (1980), sendo que para este trabalho foram consideradas taxas de $2,0,5,0$ e $8,0 \% / h$. 
Os parâmetros de degradabilidade foram determinados pelo procedimento não linear do programa computacional SAS (Statistical Analisys System, 1997).

\subsubsection{Infusão de ${ }^{15} \mathrm{~N}$ no rúmen e determinação da contaminação microbiana dos resíduos}

Após sete dias de adaptação dos animais às dietas, foram feitas infusões diárias no rúmen de dose pulso com $360 \mathrm{mg}$ de ${ }^{15} \mathrm{~N}$ na forma de $\left({ }^{15} \mathrm{NH}_{4}\right)_{2} \mathrm{SO}_{4}$ (35,6 atm\% ${ }^{15} \mathrm{~N} / \mathrm{N}$ total), imediatamente após o fornecimento da ração da manhã, sendo a infusão mantida por seis dias (Broderick \& Merchen, 1992).

A incubação dos saquinhos para estudo da degradabilidade iniciou-se três dias após a primeira infusão, quando as bactérias apresentam o máximo do seu enriquecimento (BECKERS et al. 1995). No quinto dia de aplicação de ${ }^{15} \mathrm{~N}$ no rúmen foram coletados $500 \mathrm{~g}$ de conteúdo ruminal para separação das bactérias (Cecava et al., 1990).

A amostra de conteúdo ruminal era imediatamente misturada a solução salina $(0,9 \%)$, e homogeneizado em liqüidificador por 20 segundos, sendo em seguida congelada até ao final do experimento para centrifugação. Após descongelamento o conteúdo ruminal era centrifugado a $500 \mathrm{~g}$ por 20 minutos, e o sobrenadante novamente centrifugado a $27000 \mathrm{~g}$ durante $30 \mathrm{~min}$. 0 precipitado (pellet de bactérias) foi coletado, congelado e liofilização para determinação do enriquecimento com ${ }^{15} \mathrm{~N}$.

\subsubsection{Determinação do ${ }^{15} \mathrm{~N}$ e $\mathrm{N}$ e da contaminação microbiana do resíduo}

As determinações foram realizadas no Laboratório de Isótopos Estáveis do CENA NSP, Piracicaba, SP, em espectrômetro de massa contendo analisador automático para nitrogênio, modelo ANCA-SL, da Europa Scientific LTDA (BARRIE \& PROSSER, 1996). O enriquecimento com ${ }^{15} \mathrm{~N}$ para cálculo 
da contaminação microbiana foi calculado assumindo a abundância natural desse elemento de cada alimento, determinado antes da incubação ruminal.

A contaminação microbiana do resíduo foram calculados da seguinte forma (Beckers et al., 1995):

$\%$ Nbact $=\frac{\left({ }^{15} \mathrm{~N} \% \text { atm no resíduo- }{ }^{15} \mathrm{~N} \% \text { atm no alimento }\right) \times 100}{\left({ }^{15} \mathrm{~N} \% \text { atm no pool bacteriano }-{ }^{15} \mathrm{~N} \% \text { atm no alimento }\right)}$

$\%$ MSbact $=\frac{\% \text { Nbact } \times \% \mathrm{~N} \text { resíduo }}{\% \mathrm{~N} \text { no pool bacteriano }}$

onde, \%Nbact é a \% de nitrogênio bacteriano no resíduo em relação ao nitrogênio total, \%MSbact é a \% de matéria seca microbiana no resíduo, ${ }^{15} \mathrm{~N}$ $\%$ atm é a \% de átomos de ${ }^{15} \mathrm{~N}$ no resíduo, no alimento ou no pool bacteriano.

\subsubsection{Digestibilidade intestinal in vitro da proteína bruta.}

A digestibilidade intestinal da proteína bruta foi realizada segundo técnica descrita por Casamiglia \& Stern (1995). Resíduos de incubação ruminal de $12 \mathrm{~h}$, referente à taxa de passagem de $8 \% \mathrm{~h}$, foram amostrados para conter $15 \mathrm{mg}$ de $\mathrm{N}$ e colocados em tubos de vidro pyrex de $50 \mathrm{ml}$. Foram adicionados à amostra no tubo; $10 \mathrm{ml}$ de solução de $\mathrm{HCL}(0,1 \mathrm{~N})$, contendo $1 \mathrm{~g}$ de pepsina, com pH ajustado em torno de 1,9. Após homogeneização, foi feita incubação por $1 \mathrm{~h}$ em banho-maria a $38^{\circ} \mathrm{C}$. Em seguida foram adicionados $0,5 \mathrm{ml}$ de solução de $\mathrm{NaOH} 1 \mathrm{~N}$ e 13,5 $\mathrm{ml}$ de pancreatina $(\mathrm{pH}=7,6,3 \mathrm{~g} / \mathrm{L}$ de pancreatina, $50 \mathrm{mg}$ de timol, 68g/L $\mathrm{KH}_{2} \mathrm{PO}_{4}$ e $16 \mathrm{~g} \mathrm{NaOH} / \mathrm{L}$ ), e após homogeneização, incubação em banho por $24 \mathrm{~h}$ a $38^{\circ} \mathrm{C}$, sendo os tubos agitados a cada $8 \mathrm{~h}$. Os tubos foram retirados do banho, as amostras foram filtradas e lavadas com 100 $\mathrm{ml}$ de água destilada. Após secagem das amostras em estufa de circulação forçada $\left(50^{\circ} \mathrm{C} / 24 \mathrm{~h}\right)$ foi realizada análise de nitrogênio residual (A.O.A.C., 1990). As análises foram realizadas no laboratório de Bromatologia do Instituto de Zootecnia. 


\subsubsection{Análise Bromatológica}

As amostras dos alimentos foram determinados os seguintes componentes: matéria seca a $105^{\circ} \mathrm{C}(\mathrm{MS})$, matéria mineral $(\mathrm{MM})$, extrato etéreo (EE), proteína bruta (PB) (A.O.A.C., 1990), fibra detergente neutro (FDN), fibra detergente ácido (FDA; Van Soest, et al, 1991). Os teores de $\mathrm{N}$ dos resíduos da incubação ruminal e das bactérias foram determinados durante a análise de abundância isotópica do ${ }^{15} \mathrm{~N}$ (Barrie \& Prosser, 1996).

\subsubsection{Análise estatística}

O experimento de degradação "in situ" foi desenvolvido em delineamento de Quadrado Latino $3 \times 3$ com repetição (periodos $x$ animais), em esquema de parcelas subdivididas, sendo avaliado nas parcelas períodos, animais e os niveis de concentrado $20 \%, 40 \%$ e $60 \%$ e nas subparcelas a correção microbiana (corrigido e não corrigido) e a interaçao concentrado $x$ tratamento (corrigido e não corrigido). As análises estatísticas foram efetuadas pelo Proc Mixed do programa estatístico SAS (Statistical Analisys System, 1999). Considerou-se 10 \% como nivel de significância para a probabilidade do teste $F$ para a análise de variância. A comparação entre médias de níveis de concentrados e de tratamentos (corrigidos e não corrigidos) foi realizada através do teste de Kramer-Tukey a $10 \%$ de probabilidade.

\subsection{Resultados e discussão}

As constantes de degradabilidade $a, b$ e $c$ segundo a equação de Orskov e McDonald (1979), e as degradabilidade efetivas para as taxas de passagem (kp) de 2, 5 e $8 \% / h$, bem como a comparação dos valores corrigidos ou não para contaminação microbiana da MS e PB dos diferentes alimentos, estão 
apresentados nas tabelas $3,4,5,6,7,8$. Para nenhum dos alimentos avaliados houve interação entre tratamento e correção microbiana (corrigido ou não)

Tabela 3. Componentes da curva exponencial de degradação $(a, b)$, taxa de degradação da fração $b(\mathrm{kd})$ e degradabilidade efetiva (DE) para taxas de passagem (kp) de 2, 5 e $8 \% / \mathrm{h}$, com dados corrigidos ou não para contaminação microbiana - casca de soja

\begin{tabular}{|c|c|c|c|c|c|c|c|}
\hline \multirow[b]{2}{*}{ Parâmetro } & \multicolumn{3}{|c|}{ Tratamentos } & \multicolumn{2}{|c|}{ Contaminação ${ }^{1}$} & \multicolumn{2}{|c|}{ P. } \\
\hline & $80: 20$ & $60: 40$ & $40: 60$ & Corr & Ncorr & Trat. $^{2}$ & Corr. $^{3}$ \\
\hline \multicolumn{8}{|l|}{$a(\%)$} \\
\hline MS & $20,2^{a}$ & $20,9^{\mathrm{a}}$ & $21,9^{\mathrm{b}}$ & 21,9 & 21,3 & 0,0018 & 0,0819 \\
\hline \multicolumn{7}{|l|}{$\boldsymbol{b}(\%)$} & - \\
\hline MS & 72,7 & 78,0 & 75,2 & 75,1 & 75,5 & ـ & - \\
\hline PB & $47,9^{a}$ & $47,6^{\mathrm{ab}}$ & $44,5^{b}$ & 46,6 & 46,7 & 0,0629 & - \\
\hline \multicolumn{8}{|c|}{ Taxa de degradação da fração $b, k d(\% / h)$} \\
\hline MS & $5,0^{\mathrm{a}}$ & $4,0^{b}$ & $3,0^{\mathrm{b}}$ & 4,0 & 4,0 & 0,0337 & - \\
\hline PB & 6,0 & 6,0 & 9,0 & 9,0 & 5,0 & - & - \\
\hline \multicolumn{8}{|c|}{ Degradabilidade efetiva, $k p$ de $2 \% / h$} \\
\hline MS & 69,1 & 69,9 & 68,7 & 69,6 & 68,2 & _ & _ \\
\hline PB & 81,3 & 80,5 & 79,1 & 82,4 & 78,2 & - & 0,0092 \\
\hline \multicolumn{8}{|c|}{ Degradabilidade efetiva, $\mathrm{kp}$ de $5 \% / \mathrm{h}$} \\
\hline MS & 53,3 & 52,5 & 51,9 & 53,0 & 52,1 & - & - \\
\hline PB & 71,5 & 70,7 & 70,6 & 73,5 & 68,4 & - & 0,0035 \\
\hline \multicolumn{8}{|c|}{ Degradabilidade efetiva, $\mathrm{kp}$ de $\mathbf{8 \%} / \mathbf{h}$} \\
\hline MS & 45,4 & 44,3 & 44,0 & 45,0 & 44,1 & - & - \\
\hline PB & 66,2 & 65,3 & 65,7 & 68,3 & 63,2 & - & 0,0041 \\
\hline
\end{tabular}

a,b,c Médias na mesma linha seguidas por letras diferentes são significativas $(P<0,10)$; ${ }^{1}$ Parâmetros corrigidos (Corr) ou não (NCorr) para contaminação microbiana;

${ }^{2}$ Probabilidade de efeito de tratamento, ${ }^{3}$ Probabilidade de efeito para correção.

A casca de soja (tabela 3) apresentou efeito significativo para tratamento $(P=0,004)$ para a constante "a" da equação de degradabilidade da MS, onde os valores foram superiores para animais recebendo dietas com $60 \%$ de concentrado em relação a 20 e $40 \%(21,9 \times 20,2$ e $20,9, P<0,10)$. Para a constante "b", foi verificada diferença significativa para tratamento para PB entre os tratamentos $60 \%$ e $20 \%$ de concentrado $(P<0,09)$, sendo que esses dois tratamentos não diferiram do tratamento com $40 \%$ de concentrado $(P>0,10)$. Para taxa de degradação da fração " $b$ " (Kd, \%/h) foi observada diferença 
significativa de efeito de tratamento para $M S(P<0,10)$, mas não para $P B$ $(P>0,10)$. As estimativas da degradabilidade efetiva para diferentes taxas de passagem $(2,5$ ou $8 \% / h)$ não foram significativas entre os tratamentos, tanto para a MS como para PB.

Os dados indicam que a casca de soja apresenta alta degradação da MS e da proteína bruta, estando os dados de acordo com a revisão recente de Iphaarraguerre \& Clark (2003), onde a extensão da degradação da MS da casca variou de 50,6 em $24 \mathrm{~h}$ a $100 \%$ com $72 \mathrm{~h}$ de exposição ruminal, com taxas de degradação variando de 2,5 a $5,0 \% / \mathrm{h}$. Os autores mencionam sobre a elevada degradação da porção fibrosa da casca de soja, que é devido ao baixo teor de lignina e compostos fenólicos, bem como a maior espessura e tamanho da parede celular da casca de soja, que permitem a rápida e elevada fermentação e degradação da porção fibrosa.

Os valores encontrados para os parâmetros da curva de degradação da MS e PB da casca de soja foram bastante diferentes dos relatados por Woods et al. (2002). O valor médio para MS da constante "a" foi de $6,7 \%$, para a " $b$ " de $92,0 \%$, com taxa de degradação de $4,0 \% / h$, enquanto a proteína as estimativas médias das constantes "a", " $b$ " e $k d$ foram de 18,0, 75,0 e 3,8\%/h, respectivamente. A DE estimada pelos autores com $5 \% k p$ foi de 45,8 e de $49,3 \%$ para MS e PB, respectivamente. Esses valores são bem menores que os determinados no presente trabalho para a mesma taxa de passagem, onde foi possivel observar DE de 53,0 e $73,5 \%$ para MS e PB corrigidas para contaminação microbiana, respectivamente.

As diferenças com relação ao trabalho de Woods et al. (2002) pode ter ocorrido principalmente em função das estimativas feitas para o componente "a" da equação que representa a fração solúvel, pois os autores descrevem que foram feitas correções para as perdas de partículas durante o processo de lavagem, determinando desta forma a "fração verdadeiramente solúvel em água”. 
Batajoo \& Shaver (1998) encontraram valores semelhantes ao do presente trabalho para degradação da MS da casca de soja determinado pelo método in situ, onde os valores de "a", "b", $k d$ e DE com $7 \%$ kp foram de 21,8 , $75,9,4,0$ e 48,8\%, respectivamente. Entretanto, os valores para os parâmetros de degradação da PB, foram diferentes dos encontrados neste trabalho, sendo que a DE foi de apenas $58,2 \%$ para $k p$ de $7,0 \% / h$.

Apesar de não terem sido observadas diferenças significativas $(P>0,10)$ entre os parâmetros de degradabilidade com correção ou não para contaminação microbiana, foi possível constatar efeitos significativos nas estimativas para degradabilidade efetiva da $P B(P<0,10)$ para todas as taxas de passagem. A contaminação microbiana do resíduo subestimou a DE estimada para as $k p$ de 2, 5 e $8 \% / h$ em 5,1, 6,9 e 7,5\%, respectivamente

$\mathrm{Na}$ Tabela 4 é possivel observar que no estudo da degradação da MS do milho, foram observados efeitos significativos de tratamento $(P<0,10)$ para todos os parâmetros da curva $(a, b, k d)$ e para DE. A fração "a" foi 1,1 unidade, ou $3,5 \%$ menor $(P=0,0070)$ para o tratamento com $60 \%$ de concentrado, enquanto a fração " $b$ " foi maior para o tratamento o tratamento $20 \%(P=0,02)$ em 1,8 e 1,5 unidades (2,7 e 2,3 \%) em relação aos tratamentos 40 e $60 \%$, respectivamente. $O$ tratamento com $60 \%$ de concentrado apresentou $k d$ maior em relação aos outros tratamentos $(10,0 \times 7,0$ e 8,0 \%/h; $P<0,10)$. A DE da $M S$, em todas as taxas de passagem usadas para cálculo, foi maior $(P<0,10)$ para 0 tratamento com $60 \%$ de concentrado.

Com relação aos parâmetros da curva de degradação da PB do milho, ocorreu efeito significativo de tratamento para a constante "a" $(P=0,0040)$, onde o tratamento com maior nível de concentrado $(60 \%)$ foi menor $(P<0,10)$ em relação ao tratamento com $20 \%$ de concentrado $(43,6 \times 45,9 \%$, respectivamente). A velocidade de desaparecimento da fração " $b$ " da proteina bruta foi significativamente superior $(P<0,10)$ para o tratamento com $60 \%$ de concentrado, resultando em $\mathrm{DE}$ com $k p$ de $8,0 \% / \mathrm{h}(\mathrm{P}=0,0004)$ de $69,9 \%$, ou 
cerca de 3 e $5 \%$ a mais do os valores encontrados para os tratamentos com 20 e $40 \%$ de concentrado. Para as DE estimadas com $k p$ de 2,0 e $5,0 \% / h$.

Os valores determinados no estudo de degradação da MS e PB do milho foram maiores que os encontrados por Batajoo \& Shaver (1998), que observaram degradabilidade efetiva com $k p$ de $7 \% / h$ de 51,1 e 40,0 para MS e $\mathrm{PB}$, respectivamente. Os maiores valores que encontramos para os parâmetros da curva de degradação do milho em relação aos da literatura (Nocek 1987; Herrera-Saldana et al., 1990; Batajoo \& Shaver, 1998; Moron et al., 1999), podem estar associados ao fato do milho ter sido finamente moído (aproximadamente $1,5 \mathrm{~mm}$ ).

Tabela 4. Componentes da curva exponencial de degradação (a, b), taxa de degradação da fração $b$ (kd) e degradabilidade efetiva (DE) com taxa de passagem $(\mathrm{kp})$ de 2,5 e $8 \% / \mathrm{h}$, corrigidos ou não para contaminação microbiana - milho

\begin{tabular}{|c|c|c|c|c|c|c|c|}
\hline \multirow[b]{2}{*}{ Parâmetro } & \multicolumn{3}{|c|}{ Tratamentos } & \multicolumn{2}{|c|}{ Contaminação } & \multicolumn{2}{|c|}{ P. } \\
\hline & $80: 20$ & $60: 40$ & $40: 60$ & Corr & Ncorr & Trat. $^{2}$ & Corr. ${ }^{3}$ \\
\hline \multicolumn{8}{|l|}{$a(\%)$} \\
\hline MS & $31,1^{\mathrm{a}}$ & $31,1^{\mathrm{a}}$ & $30,0^{b}$ & 30,9 & 30,6 & 0,0037 & - \\
\hline $\begin{array}{l}\text { PB } \\
\text { b (\%) }\end{array}$ & $45,9^{a}$ & $44,7^{\mathrm{ab}}$ & $43,6^{b}$ & 45,0 & 44,5 & 0,0025 & - \\
\hline MS & $66,8^{a}$ & $65,0^{b}$ & $65,3^{b}$ & 65,5 & 65,9 & 0,0122 & - \\
\hline PB & 60,2 & 61,5 & 54,7 & 57,0 & 60,6 & - & - \\
\hline \multicolumn{8}{|c|}{ Taxa de degradação da fração $b, k d(\% / h)$} \\
\hline MS & $7,0^{\mathrm{a}}$ & $8,0^{b^{3}}$ & $10,0^{c}$ & 8,0 & 8,0 & 0,0002 & _ \\
\hline PB & $5,0^{\mathrm{a}}$ & $5,0^{\mathrm{a}}$ & $8,0^{b}$ & 6,0 & 5,0 & 0,0001 & - \\
\hline \multicolumn{8}{|c|}{ Degradabilidade efetiva, kp de $2 \% / \mathrm{h}$} \\
\hline MS & $82,4^{a}$ & $82,4^{\mathrm{a}}$ & $83,3^{\mathrm{b}}$ & 82,8 & 82,6 & 0,0422 & - \\
\hline PB & 86,2 & 86,2 & 86,6 & 86,3 & 86,5 & - & - \\
\hline \multicolumn{8}{|c|}{ Degradabilidade efetiva, $k p$ de $5 \% / \mathrm{h}$} \\
\hline MS & $69,2^{a}$ & $70,3^{\mathrm{a}}$ & $72,0^{\mathrm{b}}$ & 70,7 & 70,3 & 0,0150 & - \\
\hline PB & $73,4^{a}$ & $73,2^{\mathrm{a}}$ & $76,2^{b}$ & 74,6 & 73,9 & 0,0005 & - \\
\hline \multicolumn{8}{|c|}{ Degradabilidade efetiva, $k p$ de $8 \% / h$} \\
\hline MS & $61,4^{\mathrm{a}}$ & $62,8^{a}$ & $64,7^{\mathrm{b}}$ & 63,2 & 62,8 & 0,0004 & - \\
\hline PB & $66,9^{a}$ & $66,5^{a}$ & $69,9^{b}$ & 68,2 & 67,3 & 0,0004 & - \\
\hline
\end{tabular}

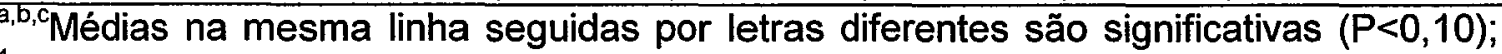
${ }^{1}$ Parâmetros corrigidos (Corr) ou não (NCorr) para contaminação microbiana; ${ }^{2}$ Probabilidade de efeito de tratamento, ${ }^{3}$ Probabilidade de efeito para correção. 
No caso do milho, as estimativas dos parâmetros da curva de degradabilidade, bem como as DE calculadas com correção para contaminação microbiana do resíduo, não apresentaram diferenças estatísticas significativas em relação aos valores estimados sem fazer a correção para contaminação. Isto provavelmente se deve ao fato da contaminação de nitrogênio bacteriano nos resíduos do milho ter sido significativamente maior apenas nos tempos de 24 e 48 h $(8,4$ e 15,5 \%Nbact, $P<0,05$, Capitulo 1$)$, não sendo suficiente para alterar parâmetros de degradabilidade.

Alexandrov (1998) relataram valores de $a, b, k d$, e de DE com $k p$ de 6 e $3 \% / h$, de $38,0,54,8,7,3,66,8$ e $76,0 \%$ para MS e $28,070,3,7,54,9$ e $67,4 \%$ para $\mathrm{PB}$, respectivamente. Ao comparem os valores dos parâmetros de degradabilidade corrigidos ou não para contaminação microbiana do resíduo, houve diferença significativa para a degradabilidade efetiva da $\mathrm{PB}$, sendo as diferenças da ordem de 7,6 e 6,4 \% para $k p$ de 6,0 e 3,0\%. As contaminações encontradas para os tempos de $0 \mathrm{~h}$ a $48 \mathrm{~h}$ de incubação ruminal apresentaram um comportamento linear, variando de 4,0 a $40,0 \%$ de nitrogênio bacteriano/nitrogênio total, enquanto que as contaminações determinadas no milho no presente trabalho foram menores principalmente para os tempos finais (24 e 48 h), comportamento esse não suficiente para alterar as constantes da curva exponencial de degradação e a degradabilidade efetiva.

Os resultados obtidos com o sorgo (Tabela 5) mostram a ausência de efeito de tratamento ou de correção para contaminação microbiana para as constantes da curva de degradação, para $k d$ e para as estimativas de DE. $O$ sorgo, semelhante ao milho, apresentou a maior \% nitrogênio bacteriano com 24 e $48 \mathrm{~h}(6,8$ e 6,1 \%Nbact). A \%MSbact máxima observada foi com $48 \mathrm{~h}$, porém de apenas $2,7 \%$ MSbact, provavelmente muito baixo para que interferisse nas estimativas dos parâmetros de degradação estudados.

Moron et al. (1999) compararam diferentes formas de processamento do sorgo sobre os parâmetros de degradabilidade ruminal da MS, sendo que o grão moído apresentou valores para "a", "b" e DE ( $k p=5 \%)$ de 18,8, 80,0 e 
$41,6 \%$, respectivamente. Zeoula et al. (1998) usando saquinhos com 23,5 mg de amostra por $\mathrm{cm}^{2}$ obtiveram valores para MS de 15,4, 83,7, 2,4, 59,9 e $31,9 \%$ para "a", "b", $k d(\% / h)$, DE com 2 e $8 \%$ de $k p$, respectivamente. Os resultados são menores que os observados neste trabalho

Valadares et al. (1991) relataram que a degradabildade da PB do sorgo foi $26 \%$ inferior à do milho, enquanto que a degradabilidade da MS dos dois alimentos foram bastante similares. Resultados semelhantes foram no presente trabalho, com DE da PB do sorgo inferior à do milho em 20,5, 28,3 e 32,5\% para os tratamentos com 20,40 e $60 \%$ de concentrado, respectivamente.

Tabela 5. Componentes da curva exponencial de degradação $(a, b)$, taxa de degradação da fração $b(k d)$ e degradabilidade efetiva (DE) com taxa de passagem $(\mathrm{kp})$ de 2,5 e $8 \% / \mathrm{h}$, corrigidos ou não para contaminação microbiana - sorgo

\begin{tabular}{|c|c|c|c|c|c|c|c|}
\hline \multirow[b]{2}{*}{ Parâmetro } & \multicolumn{3}{|c|}{ Tratamentos } & \multicolumn{2}{|c|}{ Contaminação $^{\top}$} & \multicolumn{2}{|c|}{ P. } \\
\hline & $80: 20$ & $60: 40$ & $40: 60$ & Corr & NCorr & Trat. $^{2}$ & Corr. $^{3}$ \\
\hline \multicolumn{8}{|l|}{$a(\%)$} \\
\hline MS & 35,9 & 36,1 & 36,0 & 35,7 & 36,2 & - & - \\
\hline $\begin{array}{l}\text { PB } \\
\text { b (\%) }\end{array}$ & 23,3 & 24,1 & 23,8 & 24,1 & 23,3 & - & - \\
\hline MS & 59,9 & 60,9 & 61,8 & 60,1 & 60,8 & - & - \\
\hline PB & 69,2 & 72,9 & 69,2 & 70,1 & 70,8 & - & - \\
\hline \multicolumn{8}{|c|}{ Taxa de degradação da fração $b, k d(\% / h)$} \\
\hline MS & 5,0 & 6,0 & 5,0 & 6,0 & 5,0 & - & - \\
\hline PB & 4,0 & 4,0 & 4,0 & 4,0 & 4,0 & - & - \\
\hline \multicolumn{8}{|c|}{ Degradabilidade efetiva, $k p$ de $2 \% / h$} \\
\hline MS & 79,1 & 79,7 & 79,6 & 79,8 & 79,1 & - & - \\
\hline PB & 67,6 & 70,4 & 70,2 & 70,1 & 68,7 & - & - \\
\hline \multicolumn{8}{|c|}{ Degradabilidade efetiva, $\mathrm{kp}$ de $5 \% / \mathrm{h}$} \\
\hline MS & 66,5 & 67,2 & 66,4 & 67,2 & 66,2 & - & - \\
\hline PB & 52,3 & 54,2 & 55,0 & 54,7 & 53,0 & - & - \\
\hline \multicolumn{8}{|c|}{ Degradabilidade efetiva, $k p$ de $8 \% / \mathbf{h}$} \\
\hline MS & 59,6 & 60,3 & 59,3 & 60,2 & 59,3 & - & - \\
\hline PB & 45,0 & 46,4 & 47,4 & 47,1 & 45,4 & - & - \\
\hline
\end{tabular}

a,b,c Médias na mesma linha seguidas por letras diferentes são significativa $(P<0,10)$; ${ }^{1}$ Parâmetros corrigidos (Corr) ou não (NCorr) para contaminação; ${ }^{2}$ Probabilidade de efeito de tratamento, ${ }^{3}$ Probabilidade de efeito para correção. 
Efeitos significativos para tratamento $(P=0,0600)$ foram observados para a constante $b$ da equação de degradabilidade da MS do farelo proteinoso de milho (Tabela 6 ), sendo a média do tratamento com $40 \%$ de concentrado maior $(P<0,10)$ do que as médias dos outros dois tratamentos $(20$ e $60 \%)$. A DE da MS apresentou efeitos significativos para tratamento apenas com a taxa de passagem de $2 \% / h(P=0,0600)$, onde as dieta com $60 \%$ de concentrado apresentou o menores valor.

Tabela 6. Componentes da curva exponencial de degradação $(a, b)$, taxa de degradação da fração $b$ (kd) e degradabilidade efetiva (DE) com taxa de passagem $(\mathrm{kp})$ de 2,5 e $8 \% / \mathrm{h}$, corrigidos ou não para contaminação microbiana - farelo proteinoso de milho

\begin{tabular}{|c|c|c|c|c|c|c|c|}
\hline \multirow[b]{2}{*}{ Parâmetro } & \multicolumn{3}{|c|}{ Tratamentos } & \multicolumn{2}{|c|}{ Contaminação ${ }^{1}$} & \multicolumn{2}{|c|}{ P. } \\
\hline & $80: 20$ & $60: 40$ & $40: 60$ & Corr & Ncorr & Trat. $^{2}$ & Corr. $^{3}$ \\
\hline \multicolumn{8}{|l|}{ a (\%) } \\
\hline MS & 47,8 & 48,3 & 48,5 & 48,3 & 48,1 & - & - \\
\hline $\begin{array}{l}\text { PB } \\
b(\%)\end{array}$ & $66,0^{\mathrm{a}}$ & $66,1^{a}$ & $65,5^{\mathrm{b}}$ & 66,0 & 65,8 & 0,0076 & - \\
\hline MS & $48,3^{a b}$ & $50,3^{a}$ & $42,2^{b}$ & 46,7 & 47,2 & 0,0368 & - \\
\hline PB & $30,2^{a}$ & $29,2^{b}$ & $30,2^{a}$ & 30,1 & 29,6 & 0,0003 & 0,0517 \\
\hline \multicolumn{8}{|c|}{ Taxa de degradação da fração $b, k d(\% / h)$} \\
\hline MS & 4,0 & 5,0 & 5,0 & 5,0 & 4,0 & - & - \\
\hline PB & $12,0^{\mathrm{a}}$ & $14.0^{\mathrm{ab}}$ & $15^{\mathrm{b}}$ & 14.0 & 13.0 & 0.0261 & _ \\
\hline \multicolumn{8}{|c|}{ Degradabilidade efetiva, $k p$ de $2 \% / h$} \\
\hline MS & $79,9 a$ & $79,3 a b$ & $77,8 \mathrm{~b}$ & 79,3 & 78,7 & 0,0432 & _ \\
\hline PB & 91,9 & 91,6 & 91,9 & 92,2 & 91,4 & - & 0,0048 \\
\hline \multicolumn{8}{|c|}{ Degradabilidade efetiva, $\mathrm{kp}$ de $5 \% / \mathrm{h}$} \\
\hline MS & 69,3 & 69,3 & 68,8 & 69,6 & 68,7 & - & - \\
\hline PB & 87,3 & 87,5 & 87,8 & 88,0 & 87,1 & - & 0,0239 \\
\hline \multicolumn{8}{|c|}{ Degradabilidade efetiva, $k p$ de $8 \% / h$} \\
\hline MS & 64,1 & 64,3 & 64,1 & 64,6 & 63,7 & - & - \\
\hline PB & 84,1 & 84,6 & 84,8 & 85,0 & 84,1 & - & 0,0365 \\
\hline
\end{tabular}

$\overline{a, b, c}$ Médias na mesma linha seguidas por letras diferentes são significativa $(P<0,10)$. ${ }^{1}$ Parâmetros corrigidos (Corr) ou não (NCorr) para contaminação. ${ }^{2}$ Probabilidade de efeito de tratamento, ${ }^{3}$ Probabilidade de efeito para correção.

Para degradabilidade da PB foram constatados efeitos de tratamentos $(P=0,10)$ para os parâmetros "a", " $b$ " $e$ "kd". Para a constante "a", a média foi 
menor $(P<0,10)$ para $\circ$ tratamento com $60 \%$ de concentrado $(65,5 \%)$, em relação aos outros dois tratamentos $(66,0$ e 66,1\%, respectivamente para 20 e $40 \%$ de concentrado). Para o parâmetro " $b$ " o menor valor $(P<0,10)$ foi anotado para o tratamento com $40 \%$ de concentrado $(29,2 \%)$. As diferenças estatísticas para tratamentos com relação às constantes da curva exponencial, não foram suficientes para causar diferenças estatísticas para as estimativas de DE da PB para as diferentes $k p$ usadas.

Os parâmetros de degradação encontrados por Possenti (1998) e Woods et al. (2002), tanto para a MS como para a PB do farelo proteinoso de milho são bastante semelhantes aos obtidos nesse trabalho apresentados na tabela 6 . Woods et al. (2002) ainda mencionam que não foram detectados efeitos significativos para proporção de concentrado na dieta e para nível de ingestão de MS.

O farelo proteinoso de milho mostrou-se alimento de lenta degradabilidade da MS, que segundo Firkins et al. (1991) se deve pela degradação lenta do FDN, sendo benéfico para o ambiente ruminal acarretando assim em menor sobrecarga láctica. A fração protéica apresentou degradabilidade bastante elevada, pois grande parte está na fração solúvel (Possenti, 1998), na forma de nitrogênio não protéico e de peptídeos livres.

Ao avaliar a DE da PB com $k p$ de 2, 5 e $8 \% / h$, constatou-se diferenças estatísticas $(P<0,10)$ entre os valores corrigidos e não corrigidos para contaminação microbiana do resíduo da ordem de uma unidade percentual. Apesar de significativa, a diferença é de pouca magnitude do ponto de vista prático.

Nas determinações feitas para o farelo de soja (tabela 7), a constante " $b$ " da degradação da MS e as "a" e " $b$ " da proteína bruta mostraram efeito de tratamento $(P<0,01)$. A constante $b$ da equação de degradação da MS foi maior para o tratamento com $60 \%$ de concentrado em relação aos tratamentos com 20 e $40 \%(57,5 \times 55,2$ e 55,7; $P<0,10)$. O valor da constante a da equação para PB foi cerca de 7 e $11 \%$ menor $(P<0,10)$ para o tratamento com $60 \%$ quando 
comparado com os tratamentos com 20 e $40 \%$ de concentrado, respectivamente. Para o componente " $b$ " ocorreu o contrário, com o tratamento $60 \%$ de concentrado apresentado valor maior do que os observados para os tratamentos com 20 e $40 \%$ (7 e $8 \%$, respectivamente). Não foram observadas diferenças estatísticas em nenhum dos parâmetros avaliados para correção da contaminação microbiana.

Tabela 7. Componentes da curva exponencial de degradação (a,b), taxa de degradação da fração $b(k d)$ e degradabilidade efetiva (DE) com taxa de passagem $(\mathrm{kp})$ de $2,5 \mathrm{e} 8 \% / \mathrm{h}$, corrigidos ou não para contaminação microbiana - farelo de soja

\begin{tabular}{|c|c|c|c|c|c|c|c|}
\hline \multirow[b]{2}{*}{ Parâmetro } & \multicolumn{3}{|c|}{ Tratamentos } & \multicolumn{2}{|c|}{ Contaminação ${ }^{1}$} & \multicolumn{2}{|c|}{$\mathbf{P}$. } \\
\hline & $80: 20$ & $60: 40$ & $40: 60$ & Corr & Ncorr & Trat. $^{2}$ & Corr. $^{3}$ \\
\hline \multicolumn{8}{|l|}{$a(\%)$} \\
\hline MS & 45,3 & 45,2 & 43,9 & 45,1 & 44,5 & - & - \\
\hline $\begin{array}{l}\text { PB } \\
b(\%)\end{array}$ & $36,7^{\mathrm{a}}$ & $38,2^{\mathrm{a}}$ & $34,2^{b}$ & 36,5 & 36,3 & 0,0011 & - \\
\hline MS & $55,2^{a}$ & $55,7^{\mathrm{a}}$ & $57,5^{b}$ & 55,8 & 56,4 & 0,0040 & - \\
\hline PB & $64,5^{\mathrm{a}}$ & $63,9^{\mathrm{a}}$ & $69,5^{\mathrm{b}}$ & 66,2 & 65,7 & 0,0001 & - \\
\hline \multicolumn{8}{|c|}{ Taxa de degradação da fração $b, k d(/ h)$} \\
\hline MS & 7,0 & 7,0 & 6,0 & 7,0 & 7,0 & - & - \\
\hline PB & 8,0 & 15,0 & 7,0 & 8,0 & 12,0 & - & - \\
\hline \multicolumn{8}{|c|}{ Degradabilidade efetiva, $k p$ de $2 \% / h$} \\
\hline MS & 88,2 & 88,0 & 86,6 & 87,5 & 87,5 & - & - \\
\hline PB & 87,7 & 88,2 & 87,0 & 87,8 & 87,5 & ـ & - \\
\hline \multicolumn{8}{|c|}{ Degradabilidade efetiva, $\mathrm{kp}$ de $5 \% / \mathrm{h}$} \\
\hline MS & $77,5^{\mathrm{a}}$ & $77,0^{\text {ab }}$ & $75,0^{\mathrm{b}}$ & 76,5 & 76,5 & 0,0800 & - \\
\hline PB & 75,7 & 76,8 & 73,4 & 75,3 & 75,3 & - & - \\
\hline \multicolumn{8}{|c|}{ Degradabilidade efetiva, $k p$ de $8 \% / h$} \\
\hline MS & $71,1^{\mathrm{a}}$ & $70,6^{a}$ & $68,4^{b}$ & 70,1 & 70,0 & 0,0500 & - \\
\hline PB & $68,3^{\mathrm{ab}}$ & $70,0^{\mathrm{a}}$ & $65,5^{b}$ & 67,8 & 68,1 & 0,0846 & - \\
\hline
\end{tabular}

a,b,c Médias na mesma linha seguidas por letras diferentes são significativas $(P<0,10)$. ${ }^{1}$ Parâmetros corrigidos (Corr) ou não (NCorr) para contaminação. ${ }^{2}$ Probabilidade de efeito de tratamento, ${ }^{3}$ Probabilidade de efeito para correção.

Para $k p$ de $2 \%$, não foi verificado efeito de tratamento na DE da MS e da PB. No caso de kp de $5 \%$, ocorreu efeito significativo de tratamento na DE da MS, enquanto que para $\mathrm{kp}$ de $8 \%$, o efeito de tratamento foi significativo tanto para DE da MS como da PB. Os valores de DE foram maiores para a maior 
proporção de concentrado. Weakley et al. (1983), encontraram menor desaparecimento da MS e do $\mathrm{N}$ do farelo de soja no rúmen de vacas recebendo dietas com $25 \%$ de feno de alfafa do que de vacas recebendo, 40 , 60 ou $80 \%$ de feno.

Para os parâmetros da curva de degradação ruminal do farelo de algodão (Tabela 8) apenas a $k d$ da proteina apresentou efeito significativo de tratamento $(60: 40>80: 20=40: 60, P<0,10)$. Entretanto, isto não refletiu em alterações significativas nas estimativas da degradabilidade efetiva da PB. A correção do resíduo para contaminação microbiano teve efeito significativo $(\mathrm{P}<0,10)$ na $k d$ da proteína, nas DE da MS para todas as taxas de passagem e na DE da PB da taxa de passagem de $2 \% / \mathrm{h}$.

Tabela 9. Componentes da curva exponencial de degradação $(a, b)$, taxa de degradação da fração $b$ (kd) e degradabilidade efetiva (DE) com taxa de passagem $(\mathrm{kp})$ de $2,5 \mathrm{e} 8 \% / \mathrm{h}$ corrigidos ou não para contaminação microbiana - farelo de algodão

\begin{tabular}{|c|c|c|c|c|c|c|c|}
\hline \multirow[b]{2}{*}{ Parâmetro } & \multicolumn{3}{|c|}{ Tratamentos } & \multicolumn{2}{|c|}{ Contaminação } & \multicolumn{2}{|c|}{ P. } \\
\hline & $80: 20$ & $60: 40$ & $40: 60$ & Corr & NCorr & Trat. $^{2}$ & Corr. $^{3}$ \\
\hline \multicolumn{8}{|l|}{$a(\%)$} \\
\hline MS & 26,2 & 27,6 & 26,4 & 27,6 & 25,7 & - & 0,0562 \\
\hline \multicolumn{7}{|l|}{ b (\%) } & - \\
\hline MS & 39,0 & 37,7 & 36,1 & 37,9 & 37,3 & - & - \\
\hline PB & 54,9 & 51,8 & 54,0 & 54,4 & 52,8 & & - \\
\hline \multicolumn{8}{|c|}{ Taxa de degradação da fração $b, k d(\% / h)$} \\
\hline MS & 5,0 & 5,0 & 5,0 & 5,0 & 5,0 & - & - \\
\hline PB & $13,0^{\mathrm{a}}$ & $17,0^{\mathrm{b}}$ & $12,0^{\mathrm{a}}$ & 14,0 & 13,0 & 0,0300 & - \\
\hline \multicolumn{8}{|c|}{ Degradabilidade efetiva, $k p$ de $2 \% / h$} \\
\hline MS & 52,5 & 53,0 & 51,1 & 53,4 & 51,0 & - & 0,0722 \\
\hline PB & 77,8 & 75,9 & 76,7 & 78,1 & 75,5 & - & 0,0897 \\
\hline \multicolumn{8}{|c|}{ Degradabilidade efetiva, $k p$ de $5 \% / h$} \\
\hline MS & 44,2 & 45,1 & 43,4 & 45,4 & 43,0 & - & 0,0487 \\
\hline PB & 69,6 & 69,2 & 68,1 & 70,3 & 67,6 & - & - \\
\hline \multicolumn{8}{|c|}{ Degradabilidade efetiva, $k p$ de $8 \% / \mathrm{h}$} \\
\hline MS & 39,9 & 41,0 & 39,4 & 41,3 & 39,0 & - & 0,0401 \\
\hline PB & 63,9 & 64,5 & 62,4 & 64,9 & 62,3 & - & - \\
\hline
\end{tabular}


As DE da MS do farelo de algodão foram bastante baixas em relação aos outros alimentos protéicos, provavelmente pelo alto teor de lignina observado nesse alimento (14,8 \%). Por outro lado, a degradabilidade da PB foi elevada. Valadares Filho et al. (1991) observaram em vacas gestantes e lactentes DE's para $k p$ de 2,0,5,0 e 8,0\% de 72,5, 47,2 e 38,5, respectivamente.

O farelo de algodão demonstra ser uma importante fonte de proteína degradável no rúmen, tendo a $\mathrm{DE}$ da $\mathrm{PB}$ equivalente ao farelo do farelo de soja, observação semelhante ao do trabalho de Valadares Filho et al. (1991).

No presente trabalho, com exceção do sorgo e do farelo de algodão, foi possivel observar efeito de tratamento para alguns dos parâmetros da curva de degradação. Porém, para maioria dos alimentos, não foi observado efeito do nivel de concentrado para DE, tanto da MS como da PB. Woods et al. (2002) forneceram dietas com diferentes relações de volumoso:concentrado (25:75, 50:50 e 75:25 ), com dois níveis de ingestão de MS (11 e $17 \mathrm{~g} / \mathrm{kgPV} / \mathrm{dia}$ ), e não observaram efeitos significativos nem para dieta nem para nível de ingestão para as estimativas de $a, b, k d$ e de degradabilidade efetiva, tanto para a MS como para a PB.

Para os mesmos alimentos, os valores para a constante "a" (considerada a fração solúvel) encontrados na literatura apresentam grande variação. Essa grande variação é atribuída a vários fatores, como tamanho de partículas, método de processamento, porosidade do saco e material do saquinho, além do método utilizado na lavagem (Vanzant et al. 1998; Broderick e Cochram, 2000)

Herrera-Saldana et al. (1990) relatam desaparecimento da MS maior para o trigo, seguido pela aveia, cevada e milho. Observaram que a DE da MS dos respectivos alimentos, para taxa de passagem de $6 \% / \mathrm{h}$, foram de 87,$7 ; 86,7$; 78,1 e $54,4 \%$ e a do amido de 94,$8 ; 98,4 ; 90,2$ e $61,9 \%$. Os autores destacam que o tamanho das partículas dos alimentos incubados $(1 \mathrm{~mm})$, pode explicar os maiores valores de DE encontrados por eles em relação aos observados na literatura. Segundo Vanzant et al. (1998) as pequenas partículas podem 
atravessar os poros do saco de náilon e são consideradas como perda, mas alguns autores assumem também que estas são totalmente digestíveis.

Os resultados referentes à digestibilidade intestinal in vitro $e$ às estimativas da digestibilidade total de cada alimento estão apresentados na tabela 9. A análise de variância para as duas variáveis revelou efeito altamente significativo para alimento $(P=0,0001)$, não sendo identificado efeito para tratamento ou para a interação alimento e tratamento.

Os maiores valores $(P<0,10)$ para digestibilidade intestinal da PNDR foram observados para casca de soja, milho e sorgo, enquanto que os menores foram os do farelo proteinoso de milho e do farelo de soja $(P<0,10)$. $O$ farelo de algodão apresentou valor intermediário, porém diferente estatisticamente $(P<0,10)$ dos outros alimentos. Já ao calcular a digestibilidade total da proteína, ou seja, a soma da degradação no rúmen e da digestibilidade intestinal, os alimentos diferiram entre si $(P<0,10)$, sendo que apenas o milho e o farelo proteinoso de milho apresentaram digestibilidade semelhantes $(P>0,10)$, pois teoricamente a PNDR seria a mesma.

Tabela 9. Digestibilidade Intestinal in vitro (\% PNDR) e digestibilidade total (\% PB, rúmen e intestinal in vitro) da PB dos diferentes alimentos

\begin{tabular}{lcc}
\hline Alimento & $\begin{array}{c}\text { Digestibilidade Intestinal } \\
\text { (\% PNDR) }^{1}\end{array}$ & $\begin{array}{c}\text { Digestibilidade Total } \\
\text { (\% PB) }^{1}\end{array}$ \\
\hline Casca de soja & $81,7^{\mathrm{a}}$ & $94,7^{\mathrm{a}}$ \\
Milho & $87,1^{\mathrm{a}}$ & $96,4^{\mathrm{c}}$ \\
Sorgo & $82,4^{\mathrm{a}}$ & $91,5^{\mathrm{e}}$ \\
F. de algodão & $70,9^{\mathrm{c}}$ & $92,4^{\mathrm{b}}$ \\
F. Proteinoso de milho & $57,6^{\mathrm{b}}$ & $95,9^{\mathrm{c}}$ \\
Farelo de Soja & $53,4^{\mathrm{b}}$ & $87,2^{\mathrm{d}}$ \\
\hline
\end{tabular}

$a, b, c$ Médias na mesma coluna seguidas por letras distintas são significativamente diferente $(P<0,10)$.

${ }^{1}$ Efeito de alimento $P .=0,0001$.

Casamiglia \& Stern (1995) relatam coeficiente de determinação de 0,91 $(\mathrm{P}=0,0001)$ ao comparar a técnica in vitro $\mathrm{e}$ in situ para determinar a digestibilidade intestinal da PNDR em 34 amostras de diferentes alimentos concentrados. Broderick \& Cochran (2000) revișaram diversos trabalhos e concluíram que a metodologia da digestibilidade intestinal in vitro com pepsina- 
pancreatina se mostrou adequada para estimar a digestão pós-ruminal da proteína.

Alguns sistemas utilizam valores de PBFDA para determinar a digestão intestinal da proteina (ARC, 1984; Sniffen et al., 1992). Ao analisarmos os resultados da Tabela 10, a diferença entre a digestibilidade total e $100 \%$ são bastante próximos dos valores de PB ligada ao FDA (PBFDA, tabela 1), ou seja a porção protéica indisponivel para o animal. Apesar de não ter sido feita uma análise de correlação, estes achados aparentemente confirmam as proposições de Sniffen et al. (1992) e do ARC (1984). Por outro lado Britton et al. (1986) não encontraram correlação elevada entre a digestibilidade total da PB e o teor PBFDA.

\subsection{Conclusões}

Os parâmetros das curvas de degradação dos alimentos foram afetados pelas diferentes proporções de volumoso e concentrado na dieta, com exceção do sorgo. No entanto, tais alterações só afetaram as estimativas da degradabilidade efetiva do milho (MS e PB), do farelo proteinoso de milho (MS, $k p=2 \% / h$ ), e do farelo de soja (MS e PB, $k p=8 \% / h$ ).

Diferenças significativas foram encontradas entre estimativas da DE da PB feitas com e sem correção da contaminação microbiana do resíduo da casca de soja, do farelo proteinoso de milho e do farelo de algodão $(k p=2 \%)$. Apesar de efeitos estatísticos significativos para alguns alimentos, as diferenças numéricas entre a DE corrigida ou não para contaminação microbiana do resíduo foram muito pequenas neste trabalho. Com isto em função do alto custo da técnica e o pequeno benefício que houve com as correções para contaminação microbiana, tal prática não é recomendada para estudo da cinética de degradação de alimentos concentrados. 


\section{EFEITO DA DIFERENTES PROPORÇÕES DE CONCENTRADO NA DEGRADAÇÃO E PERFIL DOS AMINOÁCIDOS}

\section{Resumo}

Foram utilizados seis bovinos Nelore canulados no rúmen dispostos em quadrado latino duplo $3 \times 3 \mathrm{com}$ repetição, com objetivo de avaliar os efeitos de diferentes proporções de concentrado $(20,40$ e $60 \%$ ) na dieta sobre a degradação e alteração no perfil de aminoácidos de diferentes fontes alimentares, corrigindo-se para contaminação microbiana. Os alimentos testados foram farelo de soja, farelo de algodão, milho, sorgo, casca de soja e farelo de glúten de milho. As incubações ruminais de amostras dos alimentos em saquinhos de nylon foram feitas por $12 \mathrm{~h}$. Não houve alteração na composição química das bactérias, quer seja para o teor de PB ou para o perfil de aminoácidos. Houve efeito apenas entre o alimentos $(P<0,05)$ para a degradação de aminoácidos, onde as menores degradações foram observadas para o sorgo e as maiores para o farelo proteinoso de milho. A degradabilidade de cada aminoácido no alimento foi bastante variável, destacando a Iso, Leu e Val, que foram os de menor degradação em relação a média dos aminoácidos totais para quase todos os alimento, com exceção da casca de soja. Os aminoácidos individuais apresentam diferentes degradações, sendo variável entre os alimentos. Estas diferenças promoveram alterações significativas $(\mathrm{P}<0,05)$ no perfil de aminoácidos dos alimentos incubados em relação ao original, devendo ser considerada pelos sistemas de avaliação de dietas. 
Effects of different concentrate ratios of nelore steers diets on degradation rate and profile of amino acids.

\section{Summary}

Six rumen cannulated Nelore steer were used in replicated latin square design $(3 \times 3)$, with the objective of analyze the effects of different ratios of concentrate $(20,40,60 \%)$ on amino acids degradation and profile changes after $12 \mathrm{~h}$ of rumen exposure. The feed evaluated were soy bean hulls, corn, sorghum grain, soy bean meal, cottonseed meal and corn gluten feed. It was not detected variations on bacterial CP and amino acid composition among diets. There was a significant effect of feed $(P<0,05)$ for amino acids degradation, with the lower values for sorghum and the higher for corn gluten feed. The individual amino acid degradability were variable with different rates of degradability, and that resulted on profile changes $(P<0,05)$ after rumen exposure, these must be considered on feed evaluation systems.

\subsection{Introdução}

A formulação de dietas para ruminantes para suprir a quantidade de aminoácidos e o adequado balanço entre eles ainda é um desafio para a nutrição moderna. Para suprir a proteína ideal para ruminantes ao nível do duodeno é necessário conhecer a composição da proteína microbiana produzida no rúmen e a da proteína de alimentos que escapam à degradação ruminal. A proteína de origem microbiana é de alta qualidade, porém a quantidade e o balanço de aminoácidos essenciais que chega ao duodeno muitas vezes pode ser inadequada, sendo incapaz de satisfazer as exigências de novilhos com elevadas taxas de crescimento. Geralmente o desempenho é menor que o esperado a não ser que seja fornecido aminoácido de origem "não 
microbiana" (O'Connor et al. 1993; NRC, 1996; Beermann et al., 1998; Kunkle e Hopkins, 1999).

Clark et al. (1992) relatam que a composição química de bactérias isoladas do rúmen de vacas podem diferir de maneira significativa em função da dieta. No entanto, segundo Varvikko et al. (1986) e Von Keyserlingk et al. (1996) a composição de aminoácidos da proteína microbiana é constante, e independente da dieta oferecida ao animal, e que qualquer alteração na composição de aminoácidos da digesta duodenal irá ocorrer devido ao perfil de aminoáciodos do alimento que escapa a degradação ruminal.

A estimativa do perfil de aminoácidos disponivel para absorção intestinal em bovinos, feitas pelo Cornell Net Carbohydrate and Protein System (CNCPS), depende de estimativas da composiçăo dos aminoácidos essenciais (metionina, lisina, histidina, fenilalanina, triptofano, treonina, leucina isoleucina, valina e arginina) disponíveis na proteina microbiana e na proteina dietética resistente à degradação no rúmen (O'Connor et al., 1993). Os modelos CNCPS (2000) e NRC (2001) assumem que o perfil de aminoácidos da proteína não degradada no rúmen (PNDR) é semelhante ao da proteína original.

No entanto, contrariamente a esta suposição a degradação dos alimentos ocorridas no rúmen pode alterar o perfil de aminoácidos, quer no aspecto qualitativo quer no quantitativo, em relação à composição dietética (Oldham, 1993; Cozzi et al., 1995; Beermann et al., 1998).

Vários trabalhos relatam a necessidade do uso de marcadores microbianos para a correta determinação do perfil de aminoácidos das frações da proteína não degradável no rúmen (Varvikko et al., 1986; Crooker et al., 1986; Cozzi et al., 1995; Von Keyserlingk et al., 1996).

Neste contexto os objetivos do presente trabalho foi de avaliar se o efeito de diferentes proporções de concentrado na degradação ruminal dos aminoácidos individuais em vários alimentos, e comparar o perfil dos aminoácidos essenciais dos alimentos após incubação com o do alimento original, corrigindo-os da contaminação microbiana. 


\subsection{Material e Métodos}

\subsubsection{Animais e dieta experimental}

O trabalho foi realizado na Estação Experimental Central do Instituto de Zootecnia, localizado no município de Nova Odessa, SP. Foram utilizados seis bovinos da raça Nelore, providos de fistula ruminal, com peso inicial de aproximadamente $380 \mathrm{~kg}$, alojados em gaiolas de metabolismo, em um delineamento Quadrado Latino $3 \times 3 \mathrm{com}$ duas repetições por tratamento em cada período. No primeiro período experimental os 6 animais foram distribuídos por sorteio para os diferentes tratamentos, sendo 2 animais para cada tratamento, e nos períodos subsequentes os animais mudavam de tratamento.

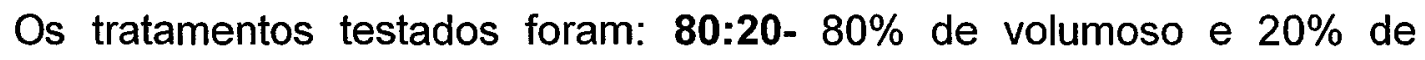
concentrado, 60:40- $60 \%$ de volumoso e $40 \%$ de concentrado ou $40: 60-40 \%$ de volumoso e $60 \%$ de concentrado. O volumoso utilizado foi a silagem de milho, e no concentrado utilizou-se milho triturado, farelo de soja, farelo de algodão, casca de soja, sorgo em grão moído e farelo proteinoso de milho. Os alimentos bem como as proporções de concentrado utilizadas foram escolhidas pois são tipicamente utilizadas em confinamentos no Brasil para bovinos Nelore.

As dietas foram formuladas com base nas exigências do "Cornell Net Carbohydrate and Protein System" (CNCPS 4.2; Fox et al., 2000), preconizando a otimização da função ruminal e balanço de nitrogênio. A quantidade de alimento fornecido (ad libitum) inicialmente foi de $100 \mathrm{~g}$ de $M S / \mathrm{kg} \mathrm{PVJ}{ }^{0,75}$, sendo realizados ajustes quando necessário, de modo que não ocorressem sobras.

$\mathrm{Na}$ tabela 1 estão os perfis de aminoácidos dos diferentes fontes alimentares estudadas. 
Tabela 1. Perfil de aminoácidos (mgAA/gAA), relação de aminoácidos e proteína bruta (\%AA/PB) e teor de proteína bruta (\%PB/MS) de diferentes fontes alimentares

\begin{tabular}{|c|c|c|c|c|c|c|}
\hline Aminoácidos \% & $\begin{array}{c}\text { F. } \\
\text { algodão }\end{array}$ & $\begin{array}{l}\text { F. de } \\
\text { soja }\end{array}$ & $\begin{array}{l}\text { F. Proteinoso } \\
\text { de milho }\end{array}$ & $\begin{array}{c}\text { Casca de } \\
\text { soja }\end{array}$ & Milho & Sorgo \\
\hline LIS & 5,8 & 8,7 & 5,1 & 10,8 & 4,4 & 3,9 \\
\hline MET & 0,9 & 0,8 & 3,9 & 0,4 & 0,9 & 0,9 \\
\hline TRE & 3,1 & 3,6 & 5,2 & 3,4 & 3,3 & 3,5 \\
\hline LEU & 5,3 & 6,3 & 13,7 & 5,8 & 10,5 & 11,7 \\
\hline ILE & 2,7 & 3,8 & 9,8 & 3,5 & 2,8 & 3,6 \\
\hline TRP & 2,2 & 3,1 & 7,0 & 1,8 & 2,6 & 2,5 \\
\hline ARG & 23,3 & 14,8 & 10,5 & 10,8 & 9,6 & 7,7 \\
\hline VAL & 4,1 & 4,2 & 1,4 & 4,5 & 5,8 & 6,1 \\
\hline PHE & 3,7 & 3,4 & 5,1 & 2,7 & 3,2 & 3,6 \\
\hline HIS & 4,2 & 3,7 & 1,2 & 4,2 & 4,7 & 3,4 \\
\hline AAEE $^{1}$ & 55,3 & 52,6 & 62,7 & 47,8 & 47,7 & 46,9 \\
\hline SER & 4,8 & 6,6 & 5,5 & 5,2 & 5,1 & 3,0 \\
\hline GLUT & 15,4 & 9,7 & 13,6 & 14,1 & 15,9 & 8,8 \\
\hline PRO & 2,9 & 5,5 & 4,4 & 9,7 & 6,4 & 1,8 \\
\hline GLI & 6,0 & 13,1 & 6,0 & 5,7 & 4,8 & 2,8 \\
\hline ALA & 5,2 & 5,7 & 5,3 & 9,2 & 11,5 & 5,0 \\
\hline TIR & 1,5 & 2,6 & 2,0 & 1,8 & 1,9 & 6,1 \\
\hline CIS & 1,1 & 0,7 & 1,07 & 1,4 & 1,1 & 8,9 \\
\hline ASP & 7,8 & 8,4 & 9,6 & 5,2 & 6,3 & 0,9 \\
\hline AANE $^{2}$ & 44,7 & 52,2 & 47,4 & 52,3 & 53,1 & 37,3 \\
\hline $\begin{array}{l}\% A A / P^{3} \\
\% P B / M^{4}\end{array}$ & $\begin{array}{l}81,0 \\
37,0 \\
\end{array}$ & $\begin{array}{l}83,6 \\
54,5 \\
\end{array}$ & $\begin{array}{l}70,3 \\
25,7\end{array}$ & $\begin{array}{l}78,5 \\
13,6 \\
\end{array}$ & $\begin{array}{l}71,9 \\
10,4 \\
\end{array}$ & $\begin{array}{l}96,0 \\
10,1\end{array}$ \\
\hline
\end{tabular}

\subsubsection{Degradabilidade dos aminoácidos.}

Os alimentos testados foram farelo de soja, farelo de algodão, farelo proteinoso de milho, casca de soja, milho moído e grão de sorgo moído, sendo 
que a escolha destes alimentos foi devido ao fato de serem freqüentemente utilizados em dietas de bovinos de corte no país.

A incubação ruminal em triplicata dos saquinhos de nylon para determinação da degradabilidade ruminal e determinação do perfil dos aminoácidos foi feita por $12 \mathrm{~h}$ (Piepenbrink e Schingoethe, 1998), sendo que as incubações foram feitas imediatamente após fornecimento da ração aos animais. Cerca de 12 gramas de cada alimento foram colocados em saquinhos de nylon $(12 \times 21 \mathrm{~cm})$ devidamente identificados, $23,8 \mathrm{mg} / \mathrm{cm}^{2}$, próximo ao intervalo de 10 a $20 \mathrm{mg} \mathrm{cm}{ }^{2}$ proposto por Nocek (1988). Os saquinhos continham 2 bolas de gude para manter os sacos submersos no rúmen, e uma argola de metal para serem fixados ao mosquetão que estava amarrado a corda de nylon de $50 \mathrm{~cm}$ de comprimento..

Após a retirada dos sacos, estes foram colocados em lavadora automática por cerca de 20 minutos, ou 4 enxágües no modo para tecidos delicados, para que a água fluísse incolor. Após lavagem os mesmos foram secos em estufa com ventilação de ar quente a $60^{\circ} \mathrm{C}$ por 72 horas, e pesados em seguida.

A degradabilidade dos aminoácidos na matéria seca foi calculada pela diferença entre quantidade do aminoácido antes e após a incubação. Os cálculos foram feitos utilizando-se a seguinte formula:

onde:

$$
\operatorname{DgAA} \%=\frac{100 \times(1-(\mathrm{AAPI})}{(\mathrm{AAAI})}
$$

DgAA\%= degradabilidade do aminoácido em porcentagem;

AAPI= gramas de aminoácidos no saco pós-incubação ruminal;

AAAl= gramas de aminoácidos no saco antes da incubação ruminal.

\subsubsection{Determinação de aminoácidos dos alimentos}

As determinações de aminoácidos essenciais (AAE): lisina, metionina, treonina, valina, leucina, isoleucina, arginina, triptofano, histidina fenilalanina e 
não essenciais (AANE): ac. aspartico, glutamina, glicina cistina, prolina, tirosina, serina e alanina das amostras dos alimentos incubadas por $12 \mathrm{~h}$ no rúmen e das bactérias isoladas foram feitas após hidrólise ácida e analisada em HPLC (cromatografia líquida de alto desempenho) no laboratório de Análises de Alimentos da Faculdade de Engenharia de Alimentos da Universidade Estadual de Campinas (FEA-UNICAMP), segundo metodologia descrita por Spackman et al. (1958). As determinações de triptofano foram feitas pelo método colorimétrico (Bernardo \& Sotelo, 1980).

Os aminoácidos foram expressos em \% de AA em relação aos aminoácidos totais (\%AA/AAT). O cálculo da relação entre proteína verdadeira (aminoácidos totais) e proteina bruta foi feito dividindo-se a quantidade de nitrogênio em cada aminoácido (AA-N) pelo $N$ total de cada amostra (CP/6,25; Tedeschi et al., 2001). A quantidade de AA-N foi calculada usando os seguintes conteúdos de $\mathrm{N}$ (\%) baseando-se em Lehninger et al. (1993): Metionina (Met), 9,4; Cistina (Cis), 11,6; Lisina (Lis), 19,2, Treonina (Tre), 11,8, Triptofano (Trp), 13,7; Arginina (Arg), 32,2; Isoleucina (lle), 10,7; Leucina (Leu), 10,7; Valina (Val), 12,0; Histidina (His), 27,1; Fenilalanina (Phe), 8,5; Glicina (Gli), 18,7; Serina (Ser), 13,3, Prolina (Pro), 12,2; Alanina (Ala), 15,7; Ac. Aspártico (Asp), 10,5 e Glutamina (Glu), 9,5 e Tirosina (Tir), 7,7.

\subsubsection{Determinação da contaminação microbiana:}

A contaminação microbiana dos resíduos de incubação ruminal foi determinada através do enriquecimento dos microrganismos com ${ }^{15} \mathrm{~N}$, com infusões diárias de sulfato de amônio enriquecido (360 mg de ${ }^{15} \mathrm{~N} / \mathrm{dia}, 35,6$ átomos\%). A separação das bactérias do conteúdo ruminal foi realizada segundo metodologia descrita por Cecava et al. (1990), para determinação do enriquecimento com ${ }^{15} \mathrm{~N}$ e do perfil de aminoácidos das mesmas. As amostras de bactérias dos animais no mesmo tratamento, dentro de cada período, foram compostas para permitir quantidade adequada. 
A contaminação microbiana do resíduo foram calculados da seguinte forma (Beckers et al., 1995):

$\%$ Nbact $=\frac{\left({ }^{15} \mathrm{~N} \% \text { atm no resíduo- }{ }^{15} \mathrm{~N} \% \text { atm no alimento }\right) \times 100}{\left({ }^{15} \mathrm{~N} \% \text { atm no pool bacteriano }-{ }^{15} \mathrm{~N} \% \text { atm no alimento }\right)}$

$\%$ MSbact $=\frac{\% \text { Nbact } x \% \mathrm{~N} \text { resíduo }}{\% \mathrm{~N} \text { no pool bacteriano }}$

onde:

$\%$ Nbact é a $\%$ de nitrogênio bacteriano no resíduo em relação ao nitrogênio total, \%MSbact é a \% de matéria seca microbiana no resíduo, ${ }^{15} \mathrm{~N}$ $\%$ atm é a \% de átomos de ${ }^{15} \mathrm{~N}$ no resíduo, no alimento ou no pool bacteriano.

A correção do perfil de aminoácidos do resíduo de incubação ruminal foi determinada da seguinte forma:

\%AAcor. = \%AAresíduo $-(\% A A b a c t ~ x \%$ MsmicrRes $) / 100$, onde:

\%AAcor é a \% de aminoácido no resíduo corrigido para contaminação microbiana; \%AAresíduo é a \% de aminoácido no resíduo da incubação ruminal (MS); \%AAbact é a \% de aminoácidos (MS) das bactérias isoladas do rúmen; e $\%$ MsmicrRes é a \% de matéria seca microbiana aderida ao resíduo.

\subsubsection{Analise estatística}

A análise estatística da degradação para cada aminoácido foi efetuada pelo SAS (Statistical Analisys System, 1999) utilizando-se o PROC MIXED com o método REML através do seguinte modelo estatístico:

$Y_{i j k l m}=\mu+\tau_{i}+\alpha_{j}+(\tau \alpha)_{i j}+P_{k}+A_{i}+\varepsilon_{i j k l m}$

onde, $\mu$ é a média geral, $\tau_{i}$ é o efeito fixo do i-ésimo tratamento, $\alpha_{j}$ é o efeito fixo do j-ésimo alimento, $(\tau \alpha)_{\mathrm{ij}}$ é o efeito fixo da interação entre o i-ésimo tratamento com o j-ésimo alimento, $P_{k}$ é o efeito aleatório do k-ésimo período, $A_{l}$ é o efeito aleatório do l-ésimo animal, e $\varepsilon_{i j k l}$ é o erro aleatório não controlável. 
Para verificar se o perfil de aminoácidos do resíduo diferiu do perfil de aminoácidos do alimento original, verificou-se se a diferença entre o teor de aminoácidos foi diferente de zero.

\subsection{Resultados e discussões}

$\mathrm{Na}$ tabela 2 são apresentados o perfil de aminoácidos de bactérias isoladas do rúmen de bovinos Nelore alimentados com dietas com diferentes proporções volumoso:concentrado. $\mathrm{Na}$ análise de variância não foi evidenciada diferença no perfil de aminoácidos das bactérias no rúmen entre os diferentes tratamentos $(P>0,05)$. Outros autores relataram observações semelhantes, onde o perfil de aminoácidos das bactérias é constante independente do tipo de dieta oferecida ao animal (Varvikko et al., 1986; Von Keyserlingk et al. 1996).

Tabela 2. Perfil de aminoácidos (mg AA/gAA), proporção de aminoácidos em relação a proteína bruta (\%AA/PB), porcentagem de nitrogênio $(\% \mathrm{~N})$ total e proteína bruta $(\% \mathrm{~PB})$ na matéria seca de bactérias isoladas do rúmen de animais diferentes fontes alimentares

\begin{tabular}{lccccc}
\hline \multicolumn{5}{c}{$\begin{array}{c}\text { Tratamentos } \\
\text { (\% Concentrado) }\end{array}$} \\
& $\mathbf{2 0}$ & $\mathbf{4 0}$ & $\mathbf{6 0}$ & média & EPM $^{1}$ \\
\hline LIS & 7.5 & 7.9 & 8.4 & 7.9 & 0,38 \\
MET & 1.0 & 1.2 & 1.3 & 1.2 & 0,09 \\
TRE & 4.1 & 4.4 & 4.1 & 4.2 & 0,12 \\
VAL & 5.7 & 5.9 & 6.0 & 5.9 & 0,11 \\
LEU & 6.7 & 7.3 & 7.3 & 7.1 & 0,19 \\
ILE & 5.4 & 5.4 & 5.3 & 5.4 & 0,05 \\
TRP & 1.3 & 1.4 & 1.2 & 1.3 & 0,05 \\
ARG & 10.1 & 9.7 & 10.2 & 10.0 & 0,26 \\
PHE & 3.7 & 3.8 & 3.8 & 3.8 & 0,06 \\
HIS & 3.0 & 3.4 & 3.4 & 3.3 & 0,14 \\
AAEE & 48.5 & 50.4 & 51.0 & 50.0 & 0,75 \\
\%AA/ PB & 63.6 & 61.0 & 65.3 & 63.3 & 0,99 \\
\%N & 6,8 & 6,6 & 6,6 & 6,6 & 0,16 \\
\%PB & 42.6 & 41.1 & 41.0 & 41.5 & 2,31 \\
\hline 1 & & & & &
\end{tabular}

'Erro padrão da média. 
Clark et al. (1992) mencionam que em trabalhos realizados em Illinois foram verificadas reduções nos coeficientes de variação para composição química das diferentes frações bacterianas, usando os mesmos protocolos para isolamento e análise laboratorial. Porém, os autores relatam que a composição química das bactérias isoladas do rúmen de vacas podem diferir de maneira significativa em função da dieta. Esse fato não foi observado no presente trabalho, provavelmente porque as dietas apresentavam os mesmos ingredientes na sua formulação, mas diferentes apenas diferentes proporções de concentrado.

O modelo de Cornell admite que a composição química das bactérias podem ser influenciadas por alterações na taxa, fase e o meio de cultura do crescimento, porém assume-se que a proteína bruta é de $62,5 \%$, carboidratos $21,1 \%$, gordura $12,0 \%$ e cinzas $4,4 \%$ (Russel et al., 1992). O teor de proteína utilizado pelo CNCPS é cerca de $33 \%$ maior que o teor de proteína encontrados no presente trabalho.

Valadares Filho et al. (1990) encontraram valores que variaram de 34,3, 38,0 e $40,7 \%$ PB na MS de bactérias isoladas do rúmen de bovinos Nelore, Holandeses e Bubalinos, respectivamente, recebendo dietas purificadas. No levantamento feito por Clark et al. (1992) em mais de 441 amostras de bactérias provenientes de 61 dietas em 35 experimentos distintos, a \%PB/MS das bactérias foi de cerca de $48 \%$, sendo que a amplitude de variação foi de 30,0 a $68,0 \%$. O valor médio de PB (na MS) das bactérias aqui observado foi de 41,5 $\% \mathrm{~PB} / \mathrm{MS}$, próximo dos valores médios encontrados por Clark et al. (1992). De forma semelhante, observou-se que o valor médio de aminoácidos em relação à PB encontrado no presente trabalho $(66,3 \%$ AA/PB) é semelhante ao encontrado na revisão citada acima (66,5\% AA/PB).

As bactérias amiloliticas apresentam taxas de crescimento e consequentemente exigência de mantença superiores as celulolíticas (150 x $0,05 \mathrm{~g}$ carboidratos/g de bactéria, respectivamente; Russel et al., 1992). Com base neste conceito, pode-se supor que ao fornecer niveis crescentes de 
concentrado na dieta criou-se um ambiente propício a maior proliferação das bactérias amilolíticas. Desta forma os dados da Tabela 2 ainda suportam a hipótese de que a composição de aminoácidos de bactérias que degradam amido não difere daquelas que degradam a fibra.

Na figura 1 é apresentado o perfil de aminoácidos de bactérias de várias fontes da literatura consultada.. Nos trabalhos avaliados não foram encontrados valores para Trp. Comparando-se o perfil de aminoácidos deste trabalho com os encontrados na literatura (figura 1), é possivel observar algumas variações. Porém os valores mostraram-se coerentes com as variações encontradas nas revisões de Clark et al. (1992) (valores mínimos e máximo) e de Boisen et al. (1999).

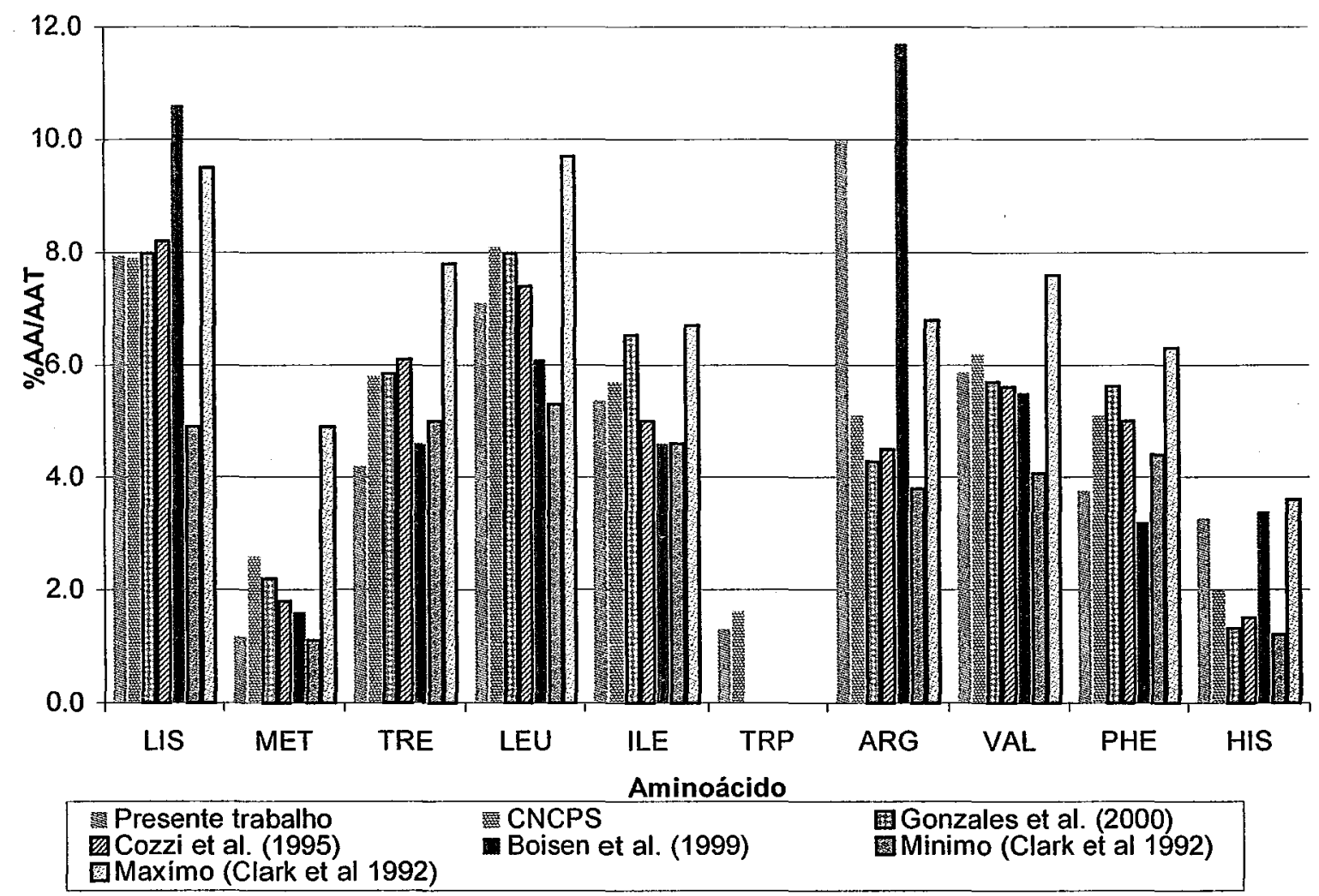

Figura 1-Perfil de aminoácidos das bactérias ruminais de trabalhos da literatura

A contaminação microbiana (\%Nbact/Nresiduo) média encontrada nos resíduos após $12 \mathrm{~h}$ de incubação determinadas com o marcador ${ }^{15} \mathrm{~N}$ foram de: 
$4,2 \%$ para o milho, $1,2 \%$ no farelo de soja, $3,2 \%$ no sorgo, $3,9 \%$ farelo de algodão, $7,2 \%$ na casca de soja, $6,9 \%$ e farelo proteinoso de milho.

A análise de variância da degradação dos aminoácidos dos alimentos após $12 \mathrm{~h}$ horas de exposição ruminal, na Tabela 3, não demonstraram efeitos de tratamento ou interação entre alimento e tratamento $(P>0,05)$. No entanto diferenças significativas foram observadas entre os alimentos $(P<0,05)$, o que era esperado devidos diferenças químicas e estruturais entre os alimentos.

Tabela 3. Degradação dos aminoácidos de diferentes alimentos após $12 \mathrm{~h}$ de incubação ruminal em bovinos Nelore

\begin{tabular}{|c|c|c|c|c|c|c|c|}
\hline & $\begin{array}{c}\text { Casca } \\
\text { de Soja }\end{array}$ & Milho & Sorgo & $\begin{array}{c}\text { Farelo de } \\
\text { Algodão }\end{array}$ & $\begin{array}{c}\text { Farelo } \\
\text { de Soja }\end{array}$ & $\begin{array}{c}\text { F. proteinoso } \\
\text { de milho }\end{array}$ & $\mathrm{EPM}^{1}$ \\
\hline LIS & $73.4^{c}$ & $78.6^{\mathrm{bc}}$ & $85.1^{\mathrm{ab}}$ & $80.5^{\mathrm{bc}}$ & $76.4^{\mathrm{bc}}$ & $91.8^{\mathrm{a}}$ & 2,6 \\
\hline MET & $75.8^{c}$ & $62.8^{d}$ & $61.3^{d}$ & $86.6^{\mathrm{ab}}$ & $77.6^{\mathrm{cb}}$ & $96.1^{\mathrm{a}}$ & 3,4 \\
\hline TRE & $80.1^{b}$ & $77.5^{b}$ & $72.0^{\mathrm{C}}$ & $83.1^{b}$ & $77.1^{b}$ & $90.7^{\mathrm{a}^{\mathrm{a}}}$. & 2,5 \\
\hline LEU & $83.4^{\mathrm{b}}$ & $70.8^{c}$ & $58.9^{d}$ & $82.3^{b c}$ & $78.0^{\mathrm{c}}$ & $92.2^{a}$ & 2,2 \\
\hline ILE & $81.5^{\mathrm{b}}$ & $77.3^{b}$ & $62.4^{c}$ & $80.9^{b}$ & $76.3^{b}$ & $93.1^{a}$ & 2,4 \\
\hline VAL & $87.2^{\mathrm{ab}}$ & $80.8^{b c}$ & $72.3^{d}$ & $80.8^{b c}$ & $73.1^{\mathrm{cd}}$ & $93.5^{a}$ & 3,2 \\
\hline TRP & $68.2^{b}$ & $91.3^{\mathrm{a}}$ & $72.5^{\mathrm{ab}}$ & $66.6^{b}$ & $75.2^{\mathrm{ab}}$ & $82.9^{\mathrm{ab}}$ & 6,1 \\
\hline ARG & $85.9^{b c}$ & $85.7^{b c}$ & $77.3^{d}$ & $86.6^{b}$ & $80.7^{\mathrm{cd}}$ & $95.0^{\mathrm{a}}$ & 1,8 \\
\hline PHE & $80.3^{b c}$ & $72.4^{\mathrm{c}}$ & $59.0^{d}$ & $82.8^{\mathrm{b}}$ & $76.8^{c}$ & $91.3^{\mathrm{a}}$ & 2,2 \\
\hline HIST & $74.4^{\mathrm{bc}}$ & $76.2^{\mathrm{bc}}$ & $69.0^{c}$ & $81.9^{b}$ & $78.3^{b}$ & $93.1^{a}$ & 2,6 \\
\hline SER & $70.9^{c}$ & $74.7^{c}$ & $65.4^{d}$ & $82,0^{b}$ & $75.7^{b c}$ & $92.3^{\mathrm{a}}$ & 2,5 \\
\hline GLU & $80.1^{b}$ & $72.9^{c}$ & $58.4^{d}$ & $84.1^{b}$ & $79.8^{b}$ & $93.7^{\mathrm{a}}$ & 2,0 \\
\hline PRO & $76.4^{\mathrm{b}}$ & $77.6^{\mathrm{b}}$ & $49.3^{c}$ & $78.3^{b}$ & $73.9^{b}$ & $93.4^{a}$ & 3.0 \\
\hline GLI & $67.6^{\mathrm{d}}$ & $77.8^{\mathrm{bc}}$ & $70.9^{d}$ & $82,0^{b}$ & $74.6^{\text {cd }}$ & $91.5^{a}$ & 2,3 \\
\hline ALA & $70.4^{\mathrm{c}}$ & $73.2^{c}$ & $59.9^{d}$ & $82.6^{\mathrm{b}}$ & $74.4^{c}$ & $93.9^{a}$ & 2,4 \\
\hline TIR & $79.0^{c}$ & $73.0^{\mathrm{d}}$ & $57.8^{\mathrm{e}}$ & $85.7^{b}$ & $75.1^{\mathrm{cd}}$ & $92.0^{a}$ & 2,3 \\
\hline Cis & $84.6^{b c}$ & $79.1^{\text {cd }}$ & $70.5^{\mathrm{d}}$ & $92.6^{\mathrm{ab}}$ & $77.8^{\text {cd }}$ & $96.8^{\mathrm{a}}$ & 2,3 \\
\hline ASP & $88.2^{\mathrm{ab}}$ & $82.3^{b}$ & $72.5^{\mathrm{c}}$ & $84.1^{\mathrm{b}}$ & $78.5^{\mathrm{c}}$ & $92.4^{\mathrm{a}}$ & 2,5 \\
\hline AAEE & $79.0^{b}$ & $77.3^{b}$ & $67.3^{d}$ & $80.2^{b}$ & $76.6^{b}$ & $92,0^{\mathrm{a}}$ & 2,2 \\
\hline AA totais & $75.3^{c}$ & $76.8^{c}$ & $65.2^{d}$ & $82.4^{b}$ & $76.4^{c}$ & $92.6^{a}$ & 1,9 \\
\hline
\end{tabular}

'Erro padrão da Média

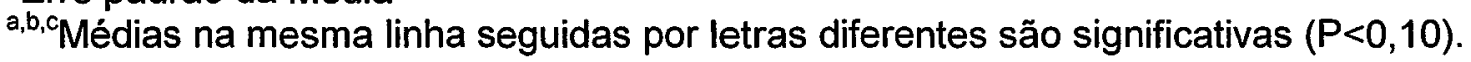

A degradação dos aminoácidos (individuais, essenciais e totais), de forma geral foram maiores para o farelo proteinoso de milho e menores nas amostras de grão de sorgo moído $(P<0,05)$. 
O farelo proteinoso de milho apresenta grande parte da sua proteína na forma solúvel (aproximadamente 48\% PB), principalmente na forma de aminoácidos e peptídeos livres, configurando ao alimento uma elevada solubilidade nas primeiras horas de incubação ruminal. Gonzales et al. (2001) fez observações semelhantes em relação a alta solubilidade do farelo proteinoso de milho, e segundo Van Straalen et al. (1997), o perfil de aminoácidos deste alimento é mais afetado pela "lavagem" pré incubação do que pela incubação ruminal.

A menor degradabilidade dos aminoácidos da proteína do sorgo pode estar relacionado à presença do composto anti-nutricional tanino, que além de indisponibilizar a proteína para degradação ruminal, pode afetar o crescimento bacteriano (Moreira et al. 1987). Entretanto, a concentração deste composto no grão de sorgo não foi determinada.

A degradação dos aminoácidos essenciais do farelo de algodão variou de 66,6 a $86,8 \%$ para Trp e Met, respectivamente, sendo que a média dos aminoácidos totais foi de $82,4 \%$. Esses dados apresentaram-se bastante elevados em relação aos relatados na literatura, onde Fernandes (2001) observou uma variação de 50,7 a 63,5 \% para Val e Lis, Valadares et al. (1992) de 15,7 a 23,58 \% para Tre e Met, enquanto O'Mara et al. (1997) relataram um desaparecimento médio dos aminoácidos totais no rúmen de $59,7 \%$. As variações encontradas em relação à média dos aminoácidos totais (Tabela 4) neste trabalho para o farelo de algodão variaram de 10,1 (Cis) a $-15,8 \%$ (Trp), sendo bem próximas às observadas no trabalho de Fernandes (2001) de $-9,3$ a $13,6 \%$. Entretanto naquele trabalho a Lis foi o aminoácido mais degradado do farelo de algodão, enquanto no presente trabalho a degradação média deste aminoácido foi semelhante à média dos aminoácidos $(-1,79 \%, P>0,05)$.

Gonzales et al. (2000), ao trabalhar com carneiros e após corrigir para contaminação microbiana os resíduos de incubação do farelo de soja com o marcador ${ }^{15} \mathrm{~N}$, encontrou degradabilidades efetivas (\%kd) para os aminoácidos bastante semelhantes às observadas neste trabalho. As médias para 
degradação efetiva para aminoáciodos totais, lisina e metionina encontradas pelos autores foram de $74,7,76,4$ e $76,2 \%$, enquanto que em nosso trabalho foram de 76,4, 76,4 e 77,6 \%, respectivamente. Ljøkjel et al. (2000) encontrou valores para degradação dos aminoácidos do farelo de soja também semelhantes às nossas observações.

Tabela 4. Variação percentual (\%) da degradação de cada aminoácido em relação a degradação média dos aminoácidos totais

\begin{tabular}{lccccccc}
\hline & $\begin{array}{c}\text { Casca de } \\
\text { soja }\end{array}$ & Milho & Sorgo & F. Algodão & F. soja & $\begin{array}{c}\text { F. proteinoso } \\
\text { de milho }\end{array}$ & EPM $^{4}$ \\
\hline LIS & $-1,0$ & 1,8 & $19,2^{*}$ & $-1,8$ & $-0,2$ & $-0,8$ & 2,10 \\
MET & $4,8^{*}$ & $-14,1^{*}$ & $-3,9$ & 4,1 & 1,4 & 3,6 & 2,22 \\
TRE & $4,9^{*}$ & 0,6 & $6,8^{*}$ & 0,7 & 0,7 & $-1,9$ & 1,30 \\
LEU & $8,3^{*}$ & $-6,1^{*}$ & $-6,5^{*}$ & $-0,1$ & $-1,4$ & $-0,4$ & 1,50 \\
ILE & $6,5^{*}$ & 0,4 & $-2,8^{*}$ & $-1,5$ & $-0,2$ & 0,5 & 1,31 \\
VAL & 11,9 & $3,9^{*}$ & $7,1^{*}$ & $-1,8$ & $-3,5$ & 0,9 & 1,99 \\
TRP & $-7,0^{*}$ & 14,4 & 6,5 & $-15,8^{*}$ & $-1,2$ & $-9,7$ & 6,38 \\
ARG & $10,3^{*}$ & $8,8^{*}$ & $12,1^{*}$ & 4,2 & 4,3 & 2,4 & 1,34 \\
PHE & 5,7 & $-4,5^{*}$ & $-6,1$ & 0,4 & 0,3 & $-1,3$ & 1,33 \\
HIS & $-0,3$ & $-0,7$ & $3,9^{*}$ & $-0,06$ & 1,9 & 0,6 & 1,54 \\
AAEE & $4,1^{*}$ & 0,5 & 2,1 & $-2,2^{*}$ & $-0,2$ & $2,1^{*}$ & 0,86 \\
& & & & & & & \\
SER & $-3,9^{*}$ & $-2,2^{*}$ & $-0,1$ & $-0,5$ & $-0,9$ & $-0,3$ & 1,19 \\
GLU & $4,5^{*}$ & $-4,0^{*}$ & $-6,8^{*}$ & 1,7 & 3,2 & 1,2 & 2,08 \\
PRO & 1,9 & 0,7 & $-15,9^{*}$ & $-4,2$ & $-2,7$ & 0,8 & 3,15 \\
GLI & $-7,2^{*}$ & 0,9 & $5,7^{*}$ & $-0,5$ & $-1,9$ & $-1,1$ & 1,28 \\
ALA & $-2,7$ & $-3,7$ & $-5,3$ & 0,2 & $-2,1$ & 1,3 & 2,20 \\
TIR & $3,9^{*}$ & $-3,9^{*}$ & $-7,4$ & $3,2^{*}$ & $-1,3$ & 0,3 & 1,15 \\
CIS & $8,6^{*}$ & $2,2^{*}$ & $5,3^{*}$ & $10,1^{*}$ & 1,4 & $4,2^{*}$ & 1,85 \\
ASP & 4,4 & 5,5 & 7,3 & 1,6 & 2,0 & $-0,2$ & 3,96 \\
\hline
\end{tabular}

${ }^{3}$ Erro padrão da média

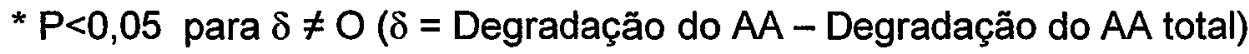

A degradação individual dos aminoácidos em cada alimento apresentou grande variabilidade, com características bastante peculiares a cada fonte utilizada, semelhantes às conclusões feitas por outros autores (Cozzi et al., 1995; Prestløkken, 1999; Miranda, 2002). Cozzi et al. (1995) avaliaram as alterações ocorridas no rúmen no farelo de soja, na protenose e farinha de peixe (arenque) e farinha de carne, concluindo que o padrão de desaparecimento dos aminoácidos é diferente entre os alimentos, e que a 
exposição ruminal modificou as proporções dos aminoácidos essenciais em relação ao original. Da mesma forma, Miranda (2002), avaliou a degradação de aminoácidos em diversas leguminosas, observando que o desaparecimento dos aminoácidos isoladamente no rúmen ocorre em diferentes extensões para cada alimento.

A degradação da Lisina e Metionina é de especial interesse pois são os principais aminoácidos limitantes em certos estádios fisiológicos (Rulquim et al. 1993). Segundo Tamiga (1979) a metionina é um dos aminoácidos de maior resistência à degradação no estômago dos ruminantes. No entanto os resultados deste trabalho, assim como os de Crooker et al. (1987), indicam que a degradação da metionina é dependente do alimento.

Ao compararmos o desaparecimento da metionina com a média de degradação dos aminoácidos totais (Tabela 4), a degradação foi da metionina no farelo proteinoso e no farelo de algodão foram numericamente maiores em relação a degradação média dos aminoácidos totais $(3,6$ e 4,1\%, respectivamente), porém sem diferenças estatísticas, ao contrario da casca de soja que a diferença foi significativa $(4,8 \%, P<0,05)$. O milho e sorgo apresentaram degradações estatisticamente menores $(P<0,05),-14,1$ e $-3,9 \%$, respectivamente. As degradações para o farelo de soja $(P>0,05)$, praticamente não sofreu alteração, sendo que a degradação foi em média apenas $1,4 \%$ superior a média total.

A Lis apresentou degradação bastante elevada, em relação à degradação dos aminoácidos totais apenas para o sorgo, em média $19 \%$ superior $(P<0,05)$. Para os outros alimentos, as alterações foram ausentes $(P>0,05)$ em relação aos aminoácidos totais, sendo de $0,2,-1,-2$ e $-1 \%$, respectivamente para farelo de soja, milho, farelo proteinoso de milho, farelo de algodão e casca de soja.

Erasmus et al. (1994) observaram que o desaparecimento da lisina no grão sorgo foi bastante acentuada, enquanto que no farelo de algodão permaneceu inalterada, resultado este coerente ao achado no presente 
trabalho. Por outro lado, naquele trabalho a Lis do milho apresentou redução significativa após $16 \mathrm{~h}$ de incubação ruminal, e neste após $12 \mathrm{~h}$ esteve inalterada. Contrário à maioria de nossas observações, O'Mara et al. (1997) relatam que dentre os aminoácidos essenciais, a lisina é um dos aminoácidos de maior degradação, também observado por Ferreira (2001) que obteve degradação ruminal média de $99,9 \%$ para milho com alto teor de Lis.

Erasmus et al. (1994) ao trabalharem com 12 fontes alimentares, relataram que os aminoácidos de cadeia ramificada, em especial para a Iso e Leu, eram mais resistentes à degradação ruminal. Outros autores relatam achados semelhantes, onde aparentemente os aminoácidos de cadeia ramificada (Val, Iso e Leu) eram mais resistentes à degradação microbiana (Varvikko et al., 1986; Harstad \& Prestløkken, 2000; Miranda, 2002).

Os aminoácidos de cadeia ramificada de modo geral (Val, Leu e Iso), em relação à média total de degradação de todos os aminoácidos apresentaram degradação semelhantes ou inferiores, especialmente para Leu e Iso. A exceção foi a casca de soja, onde as degradações para Val, Leu e Iso, foram cerca de 12, 8 e 7\% superiores à média total. A degradação da Leu em relação aos aminoácidos totais no sorgo, f. proteinoso de milho, f. de soja, milho, f. de algodão, foi de $-6,5(P<0,05), 0,4,-1,4,-6(P<0,05)$, e $-0,1 \%$, respectivamente, enquanto que a da Iso foi de, $-2,8(P<0,05), 0,5,-, 2,0,4$ e $-1,5 \%$. A degradação da Val mostrou-se variável, sendo aumentada no milho e sorgo (3,9 e $7,1 \%(P<0,05)$, respectivamente), foi menor numericamente no f. de soja ($3,5 \%, P<0,05)$, e praticamente inalterada $(P>0,05)$ à degradação média dos aminoácidos totais para o f. proteinoso de milho e f. de algodão $(0,9$ e $-1,8 \%$, respectivamente).

A viscosidade das proteínas hidrofóbicas tende a diminuir a degradação da proteína (Prestløkken, 1999), que segundo Case et al. (1995), permitiria a degradação seletiva de alguns aminoácidos. Prestløkken (1999) relatam que de forma geral, os aminoácidos hidrofóbicos (Met, Leu, Iso, Phe, Val, Ala, Tir) apresentaram menores degradações que os hidrofilicos (His, Lis, Arg, Cis, Glu 
e Ser). No entanto, no presente trabalho isto não foi regra para todos os alimentos, sendo bastante próxima à média a degradação entre os aminoácidos hidrofóbicos e hidrofílicos, exceto para o milho, onde este último grupo apresentou a degradação média cerca de $6,8 \%$ superior.

As diferenças na extensão de degradações dos aminoácidos individuais dos alimentos bem como as variações em relação à degradação de cada um dos aminoácidos, muito provavelmente, estão relacionadas ao arranjo estrutural destes na proteína de cada ingrediente, bem como a sua associação com as frações de maior ou menor degradabilidade ruminal. Von Keyserlingk et al. (1996), por exemplo, observaram que o rápido desaparecimento dos aminoácidos de cadeia ramificada da silagem de gramíneas foi pelo fato destes aminoácidos estarem associados a fração solúvel da proteina. Gonzales et al. (2001) relatam diferenças entre os perfis de aminoácidos dos resíduos de lavagem e dos resíduos de incubação ruminal de diversos alimentos, indicando variações entre os perfis de aminoácidos da fração solúvel e os da fração não degradada no rúmen dos alimentos.

As variações na degradação de cada aminoácido nos alimentos em relação à degradação média dos aminoácidos totais promoveram alterações significativas no perfil dos aminoácidos essenciais em relação aos alimentos originais (Tabela 5). Na análise de variância (Tabela 5) para comparação entre o perfil dos aminoácidos entre alimento original e incubado foi observado efeito significativo apenas para alimento $(P<0,05)$, sendo que não foi observado efeito $(P>0,05)$ de tratamento, ou da interação com alimento. Na Tabela 6 estão apresentadas em unidades percentuais as alterações em relação ao alimento original.

Em todos os alimentos houve alteração no perfil de aminoácidos em relação ao alimento original, devido às diferenças na extensão de degradação de cada aminoácido no alimento em particular. Estes resultados contrariam as suposições do NRC (2001) e o CNCPS (Fox et al. 2003), que consideraram que o perfil de aminoácidos da proteína não degradável no rúmen é semelhante 
ao perfil do alimento original, e assumem que a curva de degradação de cada aminoácido individual é semelhante.

As alterações no perfil de aminoácidos da casca de soja mais significativas estão relacionadas aos aumentos significativos $(P<0,05)$ para Lis e His, enquanto que para Leu, lle, Arg, Phe ocorreram diminuições nas suas concentrações em relação ao perfil inicial do alimento.

O milho teve alterações significativas $(P<0,05)$ para maioria dos aminoácidos, sendo que apenas Lis, Tre e lle não foram alterados. Os aminoácidos Met, Leu, Phe e His apresentaram aumentos na ordem de 53,6, $23,3,18,5$ e 30,5\% respectivamente, enquanto que Trp, Arg, Val, apresentaram redução de $-78,4,-27,6$ e -14,5\%. Comportamento semelhante para alterações no perfil de aminoácidos do milho foi relatado por Gonzales et al. (2001), onde Met, Phe, Leu e Iso aumentaram, ocorrendo decréscimo moderado para Arg, Val e Lis. Os autores relatam que a diminuição para Lis foi da ordem de $84,6 \%$, enquanto que neste trabalho foi observada uma redução de apenas $16,4 \%$. Erasmus et al (1994) também observaram alterações significativas entre o perfil de aminoácidos essenciais do milho, com redução da Tre, Val, His, Arg e Lis e aumento nas concentraçōes relativas da lle, Leu, Met e Phe.

O sorgo mostrou alterações no perfil dos aminoácidos essenciais, sendo que apenas a Met e a lle não foram alterados. O aminoácido de maior alteração em relação ao perfil do alimento original, foi a lisina, que mostrou uma redução de $58,9 \%$, em virtude principalmente da elevada degradação observada para este aminoácido no sorgo. Alterações semelhantes no perfil de aminoácidos do sorgo, de forma geral, também foram relatadas por Erasmus et al. (1994), onde a Lis foi o aminoácido que teve maior alteração (40\%), e a Met permaneceu inalterada. 


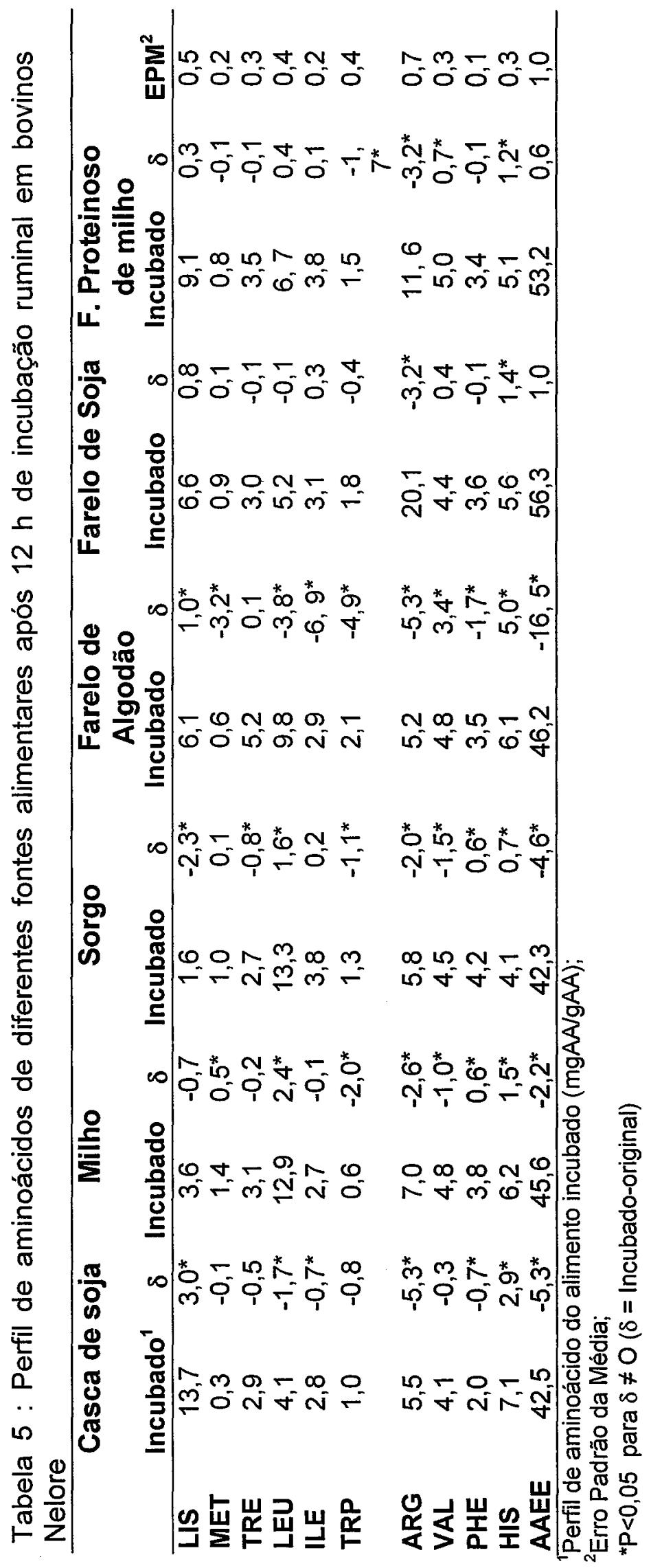


Tabela 6: Alteração do perfil de aminoácidos em relação ao alimento original $(\%)^{1}$

\begin{tabular}{lcccccc}
\hline & $\begin{array}{c}\text { Casca de } \\
\text { Soja }\end{array}$ & Milho & Sorgo & F. Algodão & F. Soja & $\begin{array}{c}\text { F. proteinoso } \\
\text { de milho }\end{array}$ \\
\hline LIS & 27,60 & $-16,41$ & $-58,97$ & 13,88 & 3,81 & 19,18 \\
MET & $-22,71$ & 53,66 & 8,99 & 4,37 & $-4,28$ & $-83,31$ \\
TRE & $-13,64$ & $-5,20$ & $-23,15$ & $-3,75$ & $-1,31$ & 1,00 \\
LEU & $-29,40$ & 23,33 & 13,76 & $-1,54$ & 5,85 & $-28,08$ \\
ILE & $-21,17$ & $-3,18$ & 6,75 & 11,50 & 1,31 & $-70,17$ \\
TRI & $-42,02$ & $-78,37$ & $-46,10$ & $-19,25$ & $-53,20$ & $-70,57$ \\
ARG & $-49,12$ & $-27,26$ & $-25,70$ & $-13,78$ & $-21,75$ & $-50,90$ \\
VAL & $-7,36$ & $-17,49$ & $-24,71$ & 8,51 & 17,07 & 248,95 \\
PHE & $-24,69$ & 18,54 & 15,18 & $-2,58$ & $-1,54$ & $-32,33$ \\
HIS & 69,13 & 30,85 & 20,06 & 34,24 & 31,13 & 430,20 \\
AAEE & $-11,06$ & $-4,54$ & $-9,89$ & 1,76 & 1,10 & $-26,25$ \\
\hline
\end{tabular}

${ }^{1}[($ Incubado-Original)/Original $] \times 100$.

Apenas o Trp, Arg, Val e His do farelo de soja apresentaram alterações em relação ao perfil de aminoácidos do alimento original $(P<0,05)$. $O$ Trp e a Arg tiveram redução de 53,2 e $21,8 \%$ em relação à concentração inicial, enquanto a Val e His aumentaram em cerca de 17,1 e $31,1 \%$, respectivamente. Os aminoácidos de maior importância, Met e Lis não apresentaram alterações significativas no seu perfil. O'Mara et al. (1997) descreveram alterações em quase todos os aminoácidos essenciais, menos para Met. Cozzi et al. (1995) notaram alterações para $\operatorname{Arg}(-31,0 \%)$, His $(-20,0 \%)$, Phe $(-8,8 \%)$ e Lis $(-24,3 \%)$. Ganev et al. (1979) encontraram poucas alterações em relação ao perfil do alimento original para os residuos de farelo de soja, farelo de girassol, farelo de nozes e farinha de peixe, após $9 \mathrm{~h}$ de incubação ruminal.

$\mathrm{O}$ alimento que apresentou as menores alterações no seu perfil foi 0 farelo de algodão, onde apenas a $\operatorname{Arg}(-13,8 \%)$ e His (34,2 \%) apresentaram alterações significativas em relação ao alimento original. Apesar de não significativas, as alterações em relação ao perfil do alimento original para Lis, lle e Trp foram de $13,88,11,5$ e $-19,3 \%$.

As maiores alterações no perfil de aminoácidos em relação ao alimento original foram observadas para o farelo proteinoso de milho para todos os aminoácidos, exceto Tre. Ambos, Lis e Met apresentaram alterações 
significativas, sendo cerca de 19.2 e $-83,3 \%$, respectivamente. As maiores alterações foram observadas para Val e Hist na ordem de 249 e $430 \%$. Os aminoácidos que apresentaram grande redução no perfil em relação aos alimentos originais (Met, Leu, lle, Trp, Arg, Phe), provavelmente são os que estariam mais associados à fração solúvel e de alta degradabilidade ruminal do farelo proteinoso do milho, como comentado anteriormente, enquanto os que aumentaram estariam associados à fração mais resistente a degradação ruminal.

Os trabalhos nos quais foram observadas maiores alterações no perfil de aminoácidos entre os resíduos de incubação e o alimento original, usaram predominantemente marcadores microbianos para determinação da contaminação microbiana, que segundo Varvikko (1986) pode afetar de forma diferente as determinações do perfil de aminoácidos da proteína não degradada no rúmen. Os erros são de menor intensidade em alimentos ricos em proteínas, porém as maiores variações ocorrem em alimentos fibrosos ou ricos em amido.

$\mathrm{Na}$ literatura existem relatos onde o perfil de aminoácidos não sofreu alteração após incubação ruminal em relação ao perfil original (Ganev et al., 1979; Varvikko et al. 1983; Boila \& Ingals,1995; Maiga et al. 1996). Boila e Ingals (1995) relataram que os aminoáciodos do farelo de canola apresentaram taxas de degradação semelhantes, não alterando o perfil da proteína não degradada no rúmen. Tedeschi et al. (2001) compararam o perfil de aminoáciodos de diversas forragens com o de seus resíduos da separação in vitro da proteína solúvel e insolúvel pela técnica tampão de borato-fosfato, concluindo que não houve diferença entre as concentrações de aminoáciodos dos alimentos originais e de seus resíduos, senso assumido que a degradação de cada aminoácido da proteina no rúmen tem taxas de degradação similar.

Varvikko (1986) concluiu que o perfil de aminoáciodos da proteína não degradada no rúmen pode ser significativamente alterado, tanto quantitativamente como qualitativamente, sendo coerentes com as observações feitas no presente trabalho. No entanto, estas alterações podem ser de maior 
ou menor intensidade em função do alimento, como por exemplo o f. de algodão e f. de soja que apresentaram menores alterações no seu perfil, principalmente em relação a Met e Lis. Outros autores trabalhando com uma gama de alimentos, e com diferentes tempos de incubação também chegaram a conclusões semelhantes (Erasmus et al.; 1994, Cozzi et al., 1995 ; Von Keyserlingk et al., 1996; O'Mara et al., 1997; Gonzales et al. 2000; Gonzales et al. 2001; Fernandes 2001, Miranda, 2002). As alterações no perfil de aminoácidos ocorrem devido as diferentes taxas de degradações observadas em cada aminoácido em particular (Von Keyserlingk et al. ,1996), como também pode ser observado no presente trabalho.

\subsection{Conclusões}

Os aminoácidos individuais apresentam diferentes degradações, sendo variável entre os alimentos. Estas diferenças promoveram alterações significativas no perfil de aminoácidos dos alimentos incubados em relação ao original, devendo ser considerada pelos sistemas de avaliação de dietas, como constados em outros trabalhos. Apesar de algumas tendências com relação aos aminoácidos de cadeia ramificadas estarem concordantes, a literatura ainda além de escassa, apresenta grande variação nos resultados, o que dificulta a criação de banco de dados. Experimentos com objetivos semelhantes ao do trabalho ainda devem ser conduzidos, para estruturação de informações de forma consolidar o banco de dados. 


\section{CONCLUSÕES GERAIS}

A contaminação do resíduo de incubação ruminal aumentou, de forma geral, com o tempo de exposição ruminal, porém a intensidade com que ocorreu variou em função da estrutura física e composição química dos ingredientes avaliados, e não em função do tratamento. Em relação a fermentação ruminal, apenas nas dietas com $60 \%$ de concentrado apresentou alterações significativas, com menores valores de $\mathrm{pH}$, maior produção de ácidos graxos voláteis, onde houve diminuição relativa de ácido acético, e aumento de ácido propiónico e butírico Os maiores valores de amônia encontrados para os tratamentos com 20 e $40 \%$ de concentrado indicam uma baixa eficiência de uso do nitrogênio pelos microrganismos ruminais, que provavelmente ocorreu devido a baixa disponibilidade de carboidratos.

Os parâmetros das curvas de degradação dos alimentos foram afetados pelas diferentes proporções de volumoso e concentrado na dieta, com exceção do sorgo. No entanto, tais alterações só afetaram as estimativas da degradabilidade efetiva do milho (MS e PB), do farelo proteinoso de milho (MS, $k p=2 \% / h$ ), e do farelo de soja (MS e PB, $k p=8 \% / h$ ).

Apesar de efeitos estatísticos significativos para alguns alimentos, as diferenças numéricas entre a DE corrigida ou não para contaminação microbiana do resíduo foram muito pequenas neste trabalho. Com isto em função do alto custo da técnica e o pequeno benefício que houve com as correções para contaminação microbiana, tal prática não é recomendada para estudo da cinética de degradação de alimentos concentrados. 
Os aminoácidos individuais apresentam diferentes degradações, sendo variável entre os alimentos. Estas diferenças promoveram alterações significativas no perfil de aminoácidos dos alimentos incubados em relação ao original, devendo ser considerada pelos sistemas de avaliação de dietas, como constados em outros trabalhos. Apesar de algumas tendências com relação aos aminoácidos de cadeia ramificadas estarem concordantes, a literatura ainda além de escassa, apresenta grande variação nos resultados, o que dificulta a criação de banco de dados. Experimentos com objetivos semelhantes ao do trabalho ainda devem ser conduzidos, para estruturação de informações de forma consolidar o banco de dados. 


\section{REFERÊNCIAS BIBLIOGRÁFICAS}

AGRICULTURE AND FOOD FESERCH CENTER. Energy and protein requirements of ruminants. Wallingford, UK: Cab International. 1993. 159p.

ASSOCIATION OF OFICIAL ANALIYTICAL CHEMISTS. Oficial Methods of Analyses. 15.ed., Atlanta, 1990, v.1. p.72-74.

AGRICULTURE RESEARCH CENTER. The Nutrient Requirements of Ruminant Livestock. Suppl, 1. Commonwealth Agriculture Bureau, 1984. 351p.

ALEXANDROV, A. N. Effect of ruminal exposure and subsequent microbial contamination on dry matter protein degradability of various feedstuffs. Animal Feed Science and Technology, v.71, p.99-107, 1998.

BACH, A.; HUNTINGTON, G. B.; CALSAMIGLIA, S; STERN, M. D.. Nitrogen metabolism of early lactation cows fed diets with two different levels of rotein and different amino acid profiles. Journal of Dairy Science, v.83, p.25852595, 2000.

BARRIE, A.; PROSSER, S. J. Automated analysis of light-element stable isotopes by isotope ratio mass spectrometry. In: BOUTTON, T. W.; YAMSAHI, S. (Ed.). Marcel Dekker, New York, 1996, p.1-46: Mass Spectrometry of soils.

BATAJOO, K. K.; SHAVER, R. D. In situ dry matter, crude protein and starch degradabilities of selectes grains and by-products feeds. Animal Feed Science and Technology, v.71, p.165-176, 1998.

BECKERS, Y. THÉWIS, A.; MAUDOUX, B.; FRANÇOIS, E.. Studies on the in situ nitrogen degradability corrected for bacterial contamination of concentrate feeds in steers. Journal of Animal Science, v.73, p.220-227, 1995.

BEERMANN, D. H.; ROBINSON, T. F.; KNAUS, W. F.; FOX, D. G. Ideal levels of absorbed amino acids boost performance. Feedstuffs, v.70, n.3, p.16-19, 54, 1998.

BERNARDO, L.; SOTELO, A. Effect of Different alkalies, temperature, and hydrolisis times on tryptophan determination of pure proteins and of foods. Analytical Biochemistry, v.109, p.192-197, 1980. 
BOILA, R. J.; INGALLS, J. R. Prediction of rumen undegradable amino acids that are digested post-ruminally. Canadian Journal of Animal Science, v.75, p.583-592, 1995.

BOISEN, S.; HVELPLUND, T.; WEISBERG, M. R. Ideal amino acid profiles as a basis for feed protein evaluation. Livestock Production Science, v.64, p.239-251, 2000.

BRITTON, R. A., T. J. KLOPFENSTEIN, R. CLEALE, F. GOEDEKEN, AND V. WILKERSON. Methods of estimating heat damage in protein sources. In: DISTILLERS FEED CONFEREBCE. Cincinnati, OH: Proceedings, Cincinati, 1986, p.41-67.

BRODERICK, G.A.; MERCHEN, N.R. Markers for quantifying Microbial protein syntesis in the rumen. Journal of Dairy Science, v.75, p.2618-2632, 1992.

BRODERICK, G. A.; COCHRAN, R. C. In vitro and in situ methods for estimating digestibility with reference to protein degradability. In: THEODOUROU, M. K.; FRANCE, J. (Ed.). Feeding systems and feed evaluation models. Wallingford: CABI Intenational, 2000. p.54-85.

CASAMIGLIA, S.; STERN, M. D. A three-step in vitro procedure for estimating intestinal digestion of protein in ruminants. Journal of Animal Science, v.73, p.1459-1465, 1995.

CECAVA, M. J.; MERCHEN, N. R.; GAY, L. C.; BERGER, L. L. Composition of ruminal bacteria harvested from steers as influenced by dietary energy level, feeding frequency, and isolation techniques. Journal of Animal Science, v.73, p.2480-2488, 1990.

CHEN, K. H.; HUBER, J. T.; THEURER, C. B.; SWINGLE, R. S.; SIMAS, J. M.; CHAN, S. C.; WU, Z.; SULLIVAN, J. L. Effect of steam flaking of corn and sorghum grains on performance of lactating cows. Journal of Dairy Science, v.77, p.1038 - 1043, 1994

$\mathrm{CHURCH}, \mathrm{D}$. C. The ruminant animal: digestive physiology and nutrition. Englewood Cliffs: Waveland Press, 1990. 563p.

CLARK, J. H.; KLUSMEYER, T. H.; CAMERON, M. R. Symposium: Nitrogen metabolism and amino acid nutrition in dairy cattle. Journal of Dairy Science, v.75, p.2304-2323, 1992

COZZI, G.; ANDRIGHETTO, I.; BERZAGHI, P. In situ ruminal disappearance of essential amino acids in protein feedstuffs. Journal of Dairy Science, v.78, p.161-171, 1995.

CROOKER, B. A.; CLARK, J. H.; SHANKS, R. D.; FAHEY Junior, J. C. Effects of ruminal exposure on the aminoacid profile of feeds. Canadian Journal of Animal Science, v.67, p.1143-1148, 1986. 
ERASMUS, L. J.; BOTHA, P. M.; CRUYWAGEN, C. W; MEISSNER, H. H. Amino acid profile and intestinal digestibility in dairy cows of rumenundegradable protein from various feedstuffs. Journal of Dairy Science, v.77, p.541-551, 1994.

DETMANN, E.; PAULINO, M. F.; ZERVOUDAKIS, J. T.; VALADARES FILHO, S. C.; LANA, R. P.; QUEIROZ, D. S. de. Suplementação de novilhos mestiços durante a época das águas: parâmetros ingestivos e digestivos. Revista Brasileira de Zootecnia, v.30, p.1340-1349, 2001.

DIXON, R. M.; CHANCHAI, S. Colonization and source of $\mathrm{N}$ substrates used by microorganisms digesting forages incubated in synthetic fibre bags in the rumen. Animal Feed Science and Technology, v.83, p.261-272, 2000.

ELIZALDE, J. C.; CREMIN Junior, J. D.; FAULKNER, D. B.; MERCHEN, N. R. Performance and digestion by steers grazing tall fescue and supplemented witth energy and protein. Journal of Animal Science, v.76, p.1691-1701, 1998.

FERNANDES, P. C. C. Modelagem da digestão da proteína e aminoácidos de alguns alimentos concentrados em ruminantes. Belo Horizonte, 2000. 95 p. Dissertação (Doutorado) Escola de Veterinária, Universidade Federal de Minas Gerais.

FIRKINS, J. L.; BERGER, L. L.; MERCHEN, N. R.; FAHEY JUNIOR., G. C.; MULVANEY, R. L. Ruminal nitrogen metabolism in steers as affected by dietary feed intake and dietary urea concentration. Journal of Dairy Science, v. 83, p.2302, 1987.

FIRKINS, J. L.; EASTRIDGE, M. L.; PALMIQUIST, D. L. Replacement of corn silage with corn gluten feed and sodium bicarbonate for lactating dairy cows. Journal of Dairy Science, v.74, p.1944-1952, 1991.

FIRKINS, J. L. Maximizing microbial protein syntesis in the rumen. Journal of Nutrition, v.126 (suppl), p.1347s-1354s, 1996.

FERREIRA, R. N. Degradação ruminal e digestibilidade intestinal e total da proteina do milho e dos germens de milho. Jaboticabal, 2001. 120p. Dissertação (Doutorado). Faculdade de Ciências Agrárias e Veterinárias, Universidade Estadual Paulista, Julio "Mesquita Filho".

FOX, D. G.; TEDESCHI, L. O.. Predicting dietary amino acid adequacy forruminants. In D'MELLO, J. P. F. (Ed). Amino Acids in Animal Nutrition. Cambridge: CABI Publishing,. 2003, p.389-410.

FOX, D. G.; TEDESCHI, L. O.; TYLUTKI, T. P.; RUSSELL, J. B.; VAN AMBURGH, M. E.; CHASE, L. E.; PELL, A. N.; OVERTON, T. R. The Cornell Net Carbohydrate and Protein System model for evaluating herd nutrition and nutrient excretion. Animal Feed Science and. Technology. 2003. (no prelo). 
FOX, D. G.; TYLUTKI, T. P..; VAN AMBURGH, M. E; CHASE, L. E..; PELL, A. N.; OVERTON, T. R.; TEDESCHI, L. O.; RASMUSSEN, C. N.; DURBAL, V. $M$. The Net Carbohydrate and protein system for evaluating herd nutrition and nutrient excretion. The Cornell University Nutrient Management Planning System. Ithaca, NY: Cornell University, 2000. 236p.

GANEV, G.; ORSKOV, E. R.; SMART, R. M. The effect of roughage or concentrate feeding and rumen retention time on total degradation of protein in the rumen. Journal of Agriculture Science. v. 93, p. 651-656, 1979.

GARTHWAITE, B. D.; SCHWAB, C. G., SLOAN, B. K. Amino acids nutrition of the early lactation cow. CORNELL NUTRITION IN: CONFERENCE FOR FEED MANUFACTURES. Ithaca, N.Y., 1998. Proceedings: Ithaca, Cornell University, 1998. p.38-50.

GONZALES, J.; CENTENO, C.; LAMRANI, F.; RODRIGUEZ, C. A. In situ rumen degradation of aminoacids from different feeds corrected for microbial contamination. Animal Research, v.50, p.253-264, 2001.

GONZALES, J.; RODRIGUES, C. A.; ANDRÉS, S. G.; ALVIR, M. R. Rumen degradability and microbial contaminantion of fish and meat meal measured by in situ technique. Animal Feed Science and Thecnology, v.73, p.71-84, 1998.

GONZALES, J.; RODRIGUES, C. A.; CENTENO, C.; LAMNARI, F. Rumen effective degradability of amino acids from soybean meal corrected for microbial contamination. Reproduction Nutrition Development, n.40, p.579586, 2000.

GRIGSBY, K. N.; KERLEY, M. S.; PATERSON, J. A.; WEIGEL, J. C. Combinations of starch and digestible fiber in supplements for steers consuming a low-quality bromegrass hay diet. Journal of Animal Science, v.71, p.1057-1064, 1993.

HARSTAD, O.M.; PRESTLØKKEN, E. Effective rumen degradability and intestinal indestibility of individual amino acids in solvent-extracted soybean meal (SBM) and xylose-treated SBM (SoyPass ${ }^{\circledR}$ ) determined in situ. Animal Feed Science and Technology, v.83, p.31-47, 2000.

HELDT, J. S.; COCHRAN, R. C; STOKKA, G. L.; FARMER, C. G.; MATHIS, C. P.; TITGEMEYER, E. C.; NAGARAJA, T. G. Effects of different suplemental sugars and starchs fed in combination with degradable intake protein on low quality forage use by beef steers. Journal of Animal Science, v.77, p.27932802, 1999a.

HELDT, J. S.; COCHRAN, R. C.; MATHIS, C. P.; WOODS, B. C.; OLSON, K. C., TITGEMEYER, E. C.; NAGARAJA, T. G.; VANZANT, E. S.; JOHNSON, D. E. Effects of level and source of carbohydrate and level of degradable intake protein on intake and digestion of low-quality tallgrass-prairie hay by beef steers. Journal of Animal Science, v.77, p.2846-2854, 1999b. 
HERRERA-SALDANA, R.E.; HUBER, J.T.; POORE, M.H. Dry matter, crude protein and starch degradability of five cereal grains. Journal of Dairy Science, v.73, n.9, p. 2386-2394, 1990.

HOOVER, W. M., STOKES, S. R. Balancing Carbohydrates and proteins for optimum rumen microbial yield. Journal of Dariry Science, v.74, p.360-372, 1991.

INSTITUT NATIONAL DE LA REECHERCHE AGRONOMIQUE. Ruminant Nutrition. Montrougue, France: John Libbey Eurotext, 1989. 389p.

IPHAARRAGUERRE, I. R.; CLARK, J. H. Soyhulls as na alternative feed for lactatinting dairy cows: A review. Journal of Dairy Science, n.86, p.10521073, 2003.

KRISNAMOORTHY, U; SNIFFEN, C. J.; STERN, M. D.; VAN SOEST, P. J. Evaluation of mathematical model of rumen digestion and an in vitro simulation of rumen proteolysis to estimate the rumen-undegraded nitrogen content of feedstuffs. British Journal of Nutrition, v.50, p.555-568, 1989.

KUNKLE, W. E.; HOPKINS, D. I. Is methionine the first limiting amino acid for growing cattle fed forages? In: ANNUAL FLORIDA NUTRITION SYMPOSIUM, Gainsville, 1999. Proceedings. Gainsville: University of Florida, 1999. p.19-29.

LEHNINGER, A. L..; NELSON, D. L.; COX, M. M. Principles of biochemistry. 2. ed. New York:Worth Publisher, 1993. cap. 5, p. 71-89.

LING, J. R.; BUTTERY, P. J. The simultaneous use of ribonucleic acid, ${ }^{35} \mathrm{~S}, 2-6-$ diaminopimelic acid, and 2-aminoethylphosphonic acid as markers for microbial nitrogen entering the duodenum of sheep. British Journal of Nutrition, v.39, p.165, 1978.

LJØKJEL, K.; HARSTAD, ${ }^{\circ}$ M.; SKREDE, A. Effect of heat treatment of soybean meal and fish meal on amino acid digestibility in mink and dairy cows. Animal Feed Science and Thecnology, v.84, p.83-95, 2000.

LÖEST, C. A.; TITGEMEYER, C. E.; LAMBERT, B. D.; TRATER, A. M. Branched-chain aminoacids for growing cattle limited-fed soybean hull-based diets. Journal of Animal Science. v.79, p.2747-2753. 2001.

LUDDEN, P. A.; CECAVA, M. J. Supplmental protein sources for steers fed corn-based diets: I. Ruminal characteristics and intestinal amino acids flows. Journal of Animal Science, v.73, p.1466-1475, 1995.

LUDDEN, P. A.; JONES, J. M.; CECAVA, M. J.; HENDRIX, K. S. Supplemental protein sources for steers fed corn-based diets: II. Growth and estimated metaboçizable amino acids supply. Journal of Animal Science, v.73, p.1476-1486, 1995. 
LYCOS, T. VARGA, G.A. Effects of processing method on degradation characteristics of protein and carbohydrate sources in situ. Journal of Dairy Science, v.78, p.1789-1801, 1995.

MAIGA, H.A.; SCHINGOETHE, D.J.; HENSON, J. E. Ruminal degradadion, aminoacids and intestinal digestibility of the residual components of five supplements. Journal of Dairy Science, v.79, p.1647-1653, 1996.

MASSON, H. A.; DEHOLM, A. M.; LING, J. R. In vivo metabolism of 2,2'Diaminopimelic acid from gram-positive and gram-negative bacterial cells by ruminal microorganisma and ruminats and its use as a marker of bacterial biomass. Applied Enviromental Microbiology, n.57, p.1714-1720, 1991.

MATHERS, J. C.; AITCHINSON, E. M. Direct estimation of the extent of contamination of food residues by microbial matter after incubation with synthetic fibre bags in the rumen. Journal of Agriculture Science, v.96, p.691-693, 1981.

MERCHEN, N.R.; TITGEMEYER, E.C. Manipulation of amino acids to the growing ruminant. Journal of Animal Science, v.70, p.3238-3247, 1992.

MERRY, R. J.; MCALLAN, A. B. Comparison of the chemical-composition of mixed bacteria harvested from the liquid and solid fractions of rumen digesta. British Journal of Nutrition, v. 50, n. 3, p.701, 1983

MIRANDA, L. F. Degradação, digestão intestinal, perfil de aminoácidos, e aminoáciodos nas frações protéicas de forragens tropicais: comparação de métodos in situ e TCA. Belo Horizonte, 2006. 96 p. Dissertação (Doutorado). Escola de Veterinária, Universidade Federal de Minas Gerais.

MOREIRA, V. R; SCHENCKEL, E.; LEBOUTE, E. M. Idendificação de taninos em leguminosas e forrageiras. In: REUNIÃO ANUAL DA SOCIEDADE BRASILEIRA DE ZOOTECNIA, 24. Brasilia, 1987. Anais. Brasilia:SBZ, 1987. p.201.

MORON, I. R.; TEIXEIRA, J. C.; OLIVEIRA, A. I. G.; PEREZ, J. R. O.; OLICEIRA, J. S. Cinética da digestão ruminal da matéria seca dos grãos de milho e sorgo submetidos a diferentes formas de processamento. Ciência e Agrotecnologia, v. 23, n.1, p.174-178, 1999.

MUPETA, B.; WEISBJERG, M.R.; HVELPLUND, T.; MADSEN, J. Digestibility of amino acids in protein rich tropical feeds for ruminats estimated with the mobile bag technique. Animal Feed Science Technology, v.69, p.271-280, 1997.

NATIONAL RESEARCH COUNCIL (N.R.C.). Nutrient Requeriments of Beef Cattle. 6. Ed. Washington, D.C.:National Academy Press, 1984. 84p.

NATIONAL RESEARCH COUNCIL (N.R.C.). Ruminant Nitrogen Usage. Washington, D.C.:National Academy Press. 1985. 138p. 
NATIONAL RESEARCH COUNCIL (N.R.C.). Nutrient Requeriments of Beef Cattle. 8 ed. Washington, D.C.: National Academy Press, 2000. 242p.

NATIONAL RESEARCH COUNCIL (N.R.C.). Nutrient Requeriments of Dairy Cattle. 8 ed. Washington, D.C.: National Academy Press, 2001. 381p.

NOCEK, J. E.; Evaluation of specific variables affecting in situ estimates of ruminal dry matter and protein digestion. Journal of Animal Science, v. 60, p.1347, 1985.

NOCEK, J. E.; Characterization of in situ dry matter and nitrogen digestion of various corn grain forms. Journal of Dairy Science, v.70. p.2291, 1987.

NOCEK, J. E. In situ and other methods to estimate ruminal protein and energy digestibility: a review. Journal of Dairy Science, v.71, p.2051-2069, 1988.

NOCEK, J. E.; RUSSELL; J. B. Protein and energy as an integrated system. Relationship of ruminal protein and carbohydrate avilability to microbial sinthesis and milk production. Journal of Dairy Science, v.71, p.2070-2107, 1988.

O'CONNOR, J. D.; SNIFFEN, C. J.; FOX, D. G.; CHALUPA, W. A net carbohydrate and protein system for evaluating cattle diets: IV. Predicting amino acids adequacy. Journal Animal Science, v.71, p.1298-1311, 1993.

OLDHAM, J. D. Recent progress towards matching feed quality to the amino acids needs of ruminants. Animal feed Science and Technology, v.45, p.19-34, 1993.

O'MARA, F. P.; MURPHY, J. L.; RATH, M. The aminoacid composition of protein feedstuffs before and after incubation and after subsequent passage through the intestines of dairy cows. Journal Animal Science, v.75, p.19411949, 1997.

ØRSKOV, E. R.; MCDONALD, I. The estimation of protein degradability in the rumen from incubation measurements weighted according to rate of passage. Journal of Agriculture Science, v.92, p.499-503, 1979.

ØRSKOV, E. R.; HOVELL, F. D..; MOULD, F. Uso de la tecnica de la bolsa de nylon para la avaluacion de los alimentos. Produccion Animal Tropical, n.5, p.213, 1980.

PALMIQUIST, D. L., WEISBJERG, M. R. HVELPLUND, T. Ruminal inestinal and total digestibilities of nutrients in cows fed diets high in fat undegradabel protein. Journal of Dairy Science, v.76, p.1353-1364, 1993.

PEREZ, J. F.; RODRIGUEZ, C. A.; GONZALES, J.; BALCELLS, J. GUADA, J. A. Contribution of dietary purine bases to duodenal digesta in sheep. In situ studies of purine degradability corrected for microbial contamination. Animal feed Science and Technology, v.62, p.251-262, 1996. 
PIEPENBRINK, M. S.; SCHINGOETHE, D. J. Ruminal degradation and amino acid composition, and estimated intestinal digetibilities of four protein supplements. Journal of Dairy Science, v.81, p.454-461, 1998.

POPPI, D.P.; McLENNAN, S.R. Protein and energy utilization by ruminants at pasture. Journal of Animal Science, v.73, p.278-290, 1995.

POSSENTI, R. A. Valor nutritivo da fibra do grão de milho através da degradabilidade in situ e digestibilidade (aparente) com ruminantes. Pirassununga, 1998. 93 p. Dissertação (Mestrado)- Faculdade de Medicina Veterinária e Zootecnia, Universidade de São Paulo.

PRESTLØKKEN, E. Ruminal degradability and intestinal digestibility of protein and amino acids in barley and oats expander-treated at various intensities. Animal Feed Science And Technology, v.82, p.157-175, 1999.

RANGNGANG, M.B.; NELSON, M.L., PARISH, S.M. Ruminal undegradability of blood meal and effects of blood meal on ruminal and postruminal digestion in steers consuming vegetative orchardgrass hay. Journal of Animal Science, v.75, p.2788-2795, 1997.

RICHARDSON, C. R.; HATFIELD, E. E. The limiting amino acid in growing cattle. Journal of Animal Science, v.46, p.740-751, 1978.

RULQUIN, H.; PISULEWSKI, R.; VERIÉ, R.; et al. Milk production and composition as function of postruminal lysine and metionine supply: $A$ nutrient-response approach. Livestock Production Science, v.37, p.69-90. 1993.

RULQUIN, H.; VÉRITÉ, R. Amino acids nutrition of dairy cows: productive effects and animal requirenments. In. GARNSWORTHY, P. C., COLE, D. J. A. (Ed). Recent developments in animal nutrition. Nottingham:Nottingham University Press, 1996. p.71-94.

RUSSEL, J. B.; O'CONNOR, J. D.; FOX, D. G.; VAN SOEST, P. J.; SNIFFEN, C. J. A net carbohydrate and protein system for evaluating cattle diets: I. Ruminal fermentation. Journal of Animal Science, v.70, p.3551-3561, 1992.

SADIK, M. S.; HUBER, J. T.; KING, K.; WANDERLEY, R.; DEYOUNG, D.; ALDEHNEH, A.; DUDAS, C. Comparison of nitrogen-15 and diaminopimelic acid for estimating bacterial protein synthesis of lactating cows fed of varying protein degradability. Journal of Dairy Science, v.73, p.694-702, 1990.

SAS Institute Inc. SAS User's guides: statistics. 6 ed. SAS Institute, Cary, NC: Cary, 1999. 213p.

SATTER, L. D.; ESDALE, W. J. In vitro lactate metabolism by ruminal ingesta. Applied Microbiology, v.60, p.680-688, 1968. 
SATTER, L. D.; SLYTER, L. L. Effect of ammonia concentration on ruminal microbial proteín production in vitro. British Journal of Nutrition. v.32, p.199-208, 1974.

SATTER, L. D., ROFFLER, R. E. Nitrogen requeriment and and utilization in dairy cattle. Journal of Dairy Science, v. 58, p.1212-1237, 1979.

SCHWAB, G. Amino acid nutrition of the dairy cow: Current status. In. Cornell Nutrition Conference for Feed Manufactures. Cornell University, Ithaca, N.Y.: Ithaca, 1996. Proceedings, 1996. p.184-198.

SCHWAB, C. G.; SOCHA, M. T.; WHITEHOUSE, N. L.. Opportunities for rumen protected lysine and methionine in lactating dairy cow nutrition. RHONEPOULENC ANIMAL NUTRITION SYMPOSIUM, Guelph, Ontario, 1993. Proceedings. Guelph, Ontario: Rhone-Poulenc, 1993, p.3-28.

SNIFFEN, C. G.; O'CONOOR, J. D.; VAN SOEST, P. J.; FOX, D. G.; RUSSEL, J. B. A net carbohydrate and protein system for evaluating cattle diets. II. Carbohydrate and protein availability. Journal of Animal Science. v.70, p.3562, 1992.

SLOAN, B; K.; GATHWAITE, B. D.; SCHWAB, C. G. Practical formulation of dairy cow diets for digestible amino acids to improve nitrogen efficiency and the botton line. In: CORNELL NUTRITION CONFERENCE FOR FEED MANUFACTURES. Cornell, 1998. Proceedings. Ithaca, N.Y: Cornell University, 1998. p.51-61.

SLYTER, L. L.; SATTER, L. D.; DINIUS, D. A. Effect of ruminal concentration on nitrogen utilization by steers. Journal of Animal Science, v.48, n.4, p.906912, 1979.

SORIANO, F. D.; POLAN, C. E.; MILLER, C. N. Milk production and composition, rumen fermentation parameters and grazing behavior of dairy cows supplemented with different forms and amounts of corn grain. Journal of Dairy Science, v.83, p.1520 - 1529, 2000.

SPACKMAN, D. H.; STEIN, W. H.; MOORE, S. Automatic recording apparatus for use in the chromatography of amino acids. Analitical Chemistry, v.30, n.3, p.1190-1206, 1958.

STOKES, S. R.; HOOVER, W. H.; MILLER, T. K. . Blauweikel, R. Ruminal digestion and microbial utilization of diets varying intake of carbohydrate and protein. Journal of Dairy Science, v.74, n.3. p. 871-881, 1991.

TAMMIGA, S. Protein degradation in the forestomachs of ruminants. Journal of Animal Science, v.49, p.375-384, 1979.

TEDESCHI, L. O. FOX, D. G.; RUSSELL, J. B. Accounting for ruminal deficiencies of nitrogen and branched-chain amino acids in the structure of the Cornell net carbohydrate and protein system. In: CORNELL NUTRITION CONFERENCE FOR FEED MANUFACTURERS, Rochester, 2000. Proceedings Rochester: University of Cornell, 2000a, p.224-238. 
TEDESCHI, L. O. FOX, D. G.; RUSSELL, J. B. Accounting for the effects of a ruminal nitrogen deficiency within the structure of the Cornell net carbohydrate and protein system. Journal of Animal Science.. v.78, p.16481658. 2000b.

TEDESCHI, L. O.; PELL, A. N.; FOX, D. G.; LLAMES, C. R. The aminoacids profiles of whole plant and of four plant residues form temperate tropical forages. Journal of Animal Science. v.79, p.525-532, 2001.

TEDESCHI, L. O.; FOX, D. G.; PELL, A. N.; LANNA, D. P. D.; BOIN. C. Development and evaluation of a tropical feed library for the cornell net carbohydrate and protein system model. Scientia Agricola, n.59, p.1-18, 2002.

TRIVELIN, P.C.O. Isótopos: nem todos são radioativos! Noticias da Escola Superior de Agricultura Luiz de Queiroz. n.15, p.10, 1990.

TRIVELIN, P.C.O. Metodologia de técnica isotópicas. Apostila. unw. cena.usp.br/apostila/trivelin. (10 de maio de 2002).

VALADARES FILHO, S. C.; SILVA, J. F. C.; SANT'ANNA, R.; LEÃO, M.; VALADARES, R. F. D.; CASTRO, A. Composição de bactérias ruminais e absorção de aminoácidos microbianos no intestino delgado de novilhos holandeses, nelores e búfalos mestiços. Revista da Sociedade Brasileira de Zootecnia, v.19. p. 431-440, 1990.

VALADARES FILHO, S. C.; SILVA, J. F. C.; LEÃO, M.; EUCLYDES, R. F.; VALADARES, R. F. D.; CASTRO, A. Degradabilidade "in situ" da proteína bruta e matéria seca de alguns alimentos em vacas gestantes e lactantes. Revista da Sociedade Brasileira de Zootecnia, v.20. p.111-122, 1991.

VAN KESSEL, J. S.; RUSSEL, J. B. The effect of amino acid nitrogen on the energetics of ruminal bacteria and its impact on energy spilling. Journal of Dairy Science, v.79, p.1237-1243, 1996.

VAN SOEST, P. J. Nutritional ecology of ruminant. Ithaca: Cornell University Press, 1994. 476p.

VAN STRAALEN, W. M.; ODINGA, J. J.; MOSTERT, W. Digestion of feed aminoacids in the rumen and small intestine of dairy cows measured with nylon bag techniques. British Journal of Nutrition, v.77, p.83-97, 1997.

VANZANT; E. S.; COCHRAN, C.; TITGEMEYER, C. Standartization of in situ techniques for ruminant feedstuff evaluation. Journal of Animal Science, v.76, p.2717-2729, 1998.

VARVIKKO, T.J. Microbially corrected amino acids composition of rumenundegraded feed and amino acid degradability in the rumen of feeds enclosed in nylon bags. British Journal of Nutrition, v.56, p.131-140, 1986. 
VARVIKKO, T.J.; LINDBERG, J.S.; SYRJÄLÄ-QVIST, L. The effect of formaldhyde treatement of soya bea, and rapeseed meal on the amino acid profiles and acid-pepsin solubility of rumen undegraded protein. Journal of Agriculture Science, v.101, p.603, 1983.

VEIRA, D. M. The role of ciliate protozoa in nutrition of the ruminant. Journal of Animal Science, v.63, p.1547-1560, 1986.

VOLDEN, $H$. Effects of level of feeding and ruminally undegraded protein on ruminal bacterial protein synthesis, escape of dietary protein, intestinal amino acids profile, and performance of dairy cows. Journal of Animal Science, v.77, p.1905-1918, 1999.

VOLDEN, H.; VELLE, E.; HARSTAD, O. M.; AULIE, A., SJAASTAD, O. V. Apparente ruminal degradation and rumen escape of lysine, methionine, and threonine admistered intra ruminally in mixtures to high-yielding cows. Journal of Animal Science, v.76, p.1232-1240, 1998.

VON KEYSERLINGK, M.G.A.. SHELFORD, J.A.; PUCHALA, R.; SWIFT, M.L; FISHER, L.J. In situ disappearence of amino acids from grass silages in the rumen and intestine of cattle. Journal of Animal Science, v.81, p.140-149, 1996.

WANDERLEY, R. C.; HUBER, J. T.; WU, Z. PESSARAKLI, M.; FONTES JUNIOR, C. Influence of microbial colonization of feed particles on determination of nitrogen degradability by in situ incubation. Journal of Animal Science, v.71, p.3073-3077, 1993.

WEAKLEY, D.C.; STERN, M.D.; SATTER, L.D. Factors affecting disapearence of feedstuffs from bags in the rumen. Journal of Animal Science, v.56, p.493-50, 1983.

WILKERSON, V. A.; KLOPFENSTEIN, T. J.; BRITON, R. A.; STOCK, R. A.; MILLER, P. S. Metabolizable protein and amino acids requeriments of growing cattle. Journal of Animal Science, v.71, p.2777-2784, 1993.

WOODS, V. B.; O'MARA, F. P.; MOLONEY, A. P. The in situ ruminal degradability of concentrate feedstuffs in steers as affected by level of feed consuption and ratio of grass silage to concentrate. Animal Feed Science and Technology. v.100, p.15-30, 2002

ZEOULA, L. M; ALCALDE, C. R.; FREGADO, F. L.; RAYMUNDO, P. T.; BRANCO, A. F.; DAMASCENO, J. C. Degradação ruminal de grãos de cereais e da raspa de mandioca amassados (compact disc). In: REUNIÃO ANUAL DA SOCIEDADE BRASILEIRA DE ZOOTECNIA, Botucatu, 1998. Anais. Botucatu:SBZ. 1998.

ZINN, R. A.; OWENS, F. N. A rapid procedure for purine measurement and its use for estimating net ruminal protein syntesis. Canadian Journal of Animal Science, v.66, p.157-166, 1986. 